\begin{tabular}{|c|c|c|c|c|c|c|}
\hline \multirow{4}{*}{ Impact Factor: } & ISRA (India) & $=3.117$ & SIS (USA) & $=0.912$ & ICV (Poland) & $=6.630$ \\
\hline & ISI (Dubai, UAE & $=0.829$ & РИНЦ (Russia & $=0.156$ & PIF (India) & $=1.940$ \\
\hline & GIF (Australia) & $=0.564$ & ESJI (KZ) & $=8.716$ & IBI (India) & $=4.260$ \\
\hline & JIF & $=1.500$ & SJIF (Morocco & $=5.667$ & OAJI (USA) & $=0.350$ \\
\hline
\end{tabular}

\begin{tabular}{|c|c|}
\hline \multicolumn{2}{|c|}{$\begin{array}{l}\text { SOI: } \underline{1.1 / \mathrm{TAS}} \text { DOI: } \underline{10.15863 / \mathrm{TAS}} \\
\text { International Scientific Journal } \\
\text { Theoretical \& Applied Science }\end{array}$} \\
\hline p-ISSN: 2308-4944 (print) & e-ISSN: 2409-0085 (online) \\
\hline Year: 2019 & Volume: 71 \\
\hline Published: 19.03 .2019 & http://T-Science.org \\
\hline
\end{tabular}

UDC 685. 74 519. 37.

SECTION: Technical sciences
QR - Issue

QR - Article
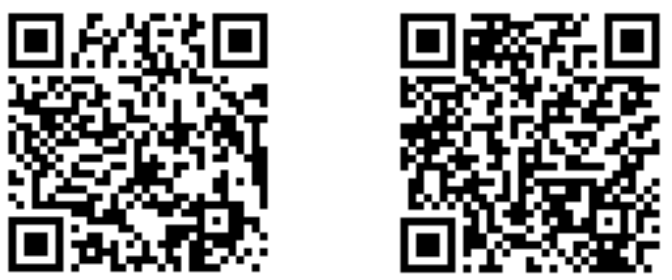

Artur Alexandrovich Blagorodov bachelor, Department of "Design, technology, and design" Institute of service sector and entrepreneurship (branch) of DSTU in Shakhty, Rostov region bordux1995@icloud.com

Dmitry Olegovich Bordukh

bachelor, Department of "Design, technology, and design" Institute of service sector and entrepreneurship (branch) of DSTU in Shakhty, Rostov region bordux1995@icloud.com

Angelina Vladimirovna Kopylova bachelor, Department of "Design, technology, and design" Institute of service sector and entrepreneurship (branch) of DSTU in Shakhty, Rostov region prohorov@sssu.ru

Daria Sergeevna Smolina

bachelor, Department of "Design, technology, and design" Institute of service sector and entrepreneurship (branch) of DSTU in Shakhty, Rostov region prohorov@sssu.ru

Vladimir Timofeevich Prokhorov Doctor of technical sciences, professor, Professor the department "Designing, technology and design", ISOP (f) DGTU, Shakhty prohorov@sssu.ru

Yuri Dmitrievich Mishin Professor, candidate of philosophy, Department of Philosophy and Culturology "Siberian state University of railway communication" Novosibirsk vinichenkoan@stu.ru

\title{
MANAGEMENT FEATURES QUALITY OF DIGITAL DEFECT-FREE PRODUCTION OF IMPORT-SUBSTITUTING PRODUCTS FOR CONSUMERS IN THE REGIONS OF SFD AND SCFO (2 MESSAGE)
}

Abstract: in the message 2 the possibilities of production of competitive and demanded production which are possible only in the presence of the heads professionally prepared and politically responsible for results of the activity are considered. The authors reasonably believe that the political responsibility of the heads of light industry enterprises is the highest measure of expression of their professionalism. But at the same time, I would like to note that their failure to fulfill political promises and statements is evidence of either their inability to engage in economic policy, or the use of political governance is carried out in their personal interests, alien to the interests of society, provoking the impoverishment of the people, characterizing the immorality of leaders, which, of course, is 


\begin{tabular}{lrllll} 
ISRA $($ India $)$ & $=\mathbf{3 . 1 1 7}$ & SIS $($ USA) & $=\mathbf{0 . 9 1 2}$ & ICV $($ Poland) & $=\mathbf{6 . 6 3 0}$ \\
ISI $($ Dubai, UAE) & $=\mathbf{0 . 8 2 9}$ & PUHЦ $($ Russia $)=\mathbf{0 . 1 5 6}$ & PIF $($ India $)$ & $=\mathbf{1 . 9 4 0}$ \\
GIF $($ Australia $)$ & $=\mathbf{0 . 5 6 4}$ & ESJI $($ KZ $)$ & $=\mathbf{8 . 7 1 6}$ & IBI $($ India $)$ & $=\mathbf{4 . 2 6 0}$ \\
JIF & $=\mathbf{1 . 5 0 0}$ & SJIF $($ Morocco $)=\mathbf{5 . 6 6 7}$ & OAJI $($ USA) & $=\mathbf{0 . 3 5 0}$ \\
\hline
\end{tabular}

unacceptable. And it is clear that there are no objective reasons that would justify the decline in production in light industry, so the results of the assessment of economic policy should be either useful or harmful -it should always be axiomatic. If this does not happen, then something in this very economic policy is not a professional decision, actions are harmful to society and timely adjustments are necessary. The authors recommend the market to revise the concept of the formation of its demand and import-substituting goods, taking into account their attractiveness. This concept will fully comply with the consumer's desire to satisfy their desire and desire to make a purchase, taking into account their social status, providing manufacturers with the sale of their products in full and guaranteeing businesses sustainable TPE of their activities.

Key words: QMS, certification, import substitution, demanded, conformity assessment, standardization, audit, demand, defective products, Pareto chart, quality policy and objectives, documentation, effectiveness, efficiency, responsibility

Language: Russian

Citation: Blagorodov, A. A., Bordukh, D. O., Kopylova, A. V., Smolina, D. S., Prokhorov, V. T., \& Mishin, Y. D. (2019). Management features quality of digital defect-free production of import-substituting products for consumers in the regions of SFD and SCFO (2 message). ISJ Theoretical \& Applied Science, 03 (71), 248-302.

Soi: http://s-o-i.org/1.1/TAS-03-71-19 Doi: crossef https://dx.doi.org/10.15863/TAS.2019.03.71.19

\section{ОСОБЕННОСТИ УПРАВЛЕНИЯ КАЧЕСТВОМ ЦИФРОВОГО ПРОИЗВОДСТВА БЕЗДЕФЕКТНОЙ ИМПОРТОЗАМЕЩАЕМОЙ ПРОДУКЦИИ ДЛЯ ПОТРЕБИТЕЛЕЙ РЕГИОНОВ ЮФО И СКФО (СООБЩЕНИЕ 2)}

Аннотация: В сообщении 2 рассмотрены возможности производства конкурентоспособной и востребованной продукиии, которые возможны лишь при наличии руководителей, профессионально подготовленных и политически ответственных за результаты своей деятельности. Авторы обоснованно считают, что в политической ответственности руководителей предприятий лёгкой промышленности и есть высшая мера выражения их профессионализма. Но при этом хотелось отметить, что невыполнение ими политических обещзаний и заявлений - это свидетельство либо их неспособности заниматься экономической политикой, либо использование политического управления осуществляется ими в личных интересах, чуждых интересам общества, провоцирующче обнищание народа, характеризующие безнравственность руководителей, что, конечно, недопустимо. И понятно, что нет таких объективных причин, которые оправдали бы спад производства в лёгкой промышленности, поэтому результаты оценки экономической политики должны быть либо полезными, либо вредными - это должно быть всегда аксиомой. Если этого не происходит, значит что-то в этой самой экономической политике не профессиональное решение, действия вредны для общества и необходимы своевременные коррективы. Авторы рекомендуют рынку пересмотреть концепцию по формированию его востребованными и импортозамещаемыми товарами с учетом их привлекательности. Такое понятие в полной мере будет соответствовать желанию потребителя удовлетворить свое стремление и желание совериить покупку с учетом своего социильного статуса, обеспечивая производителям реализацию изготовленной ими продукциии в полном объеме и гарантируя предприятиям устойчивые ТЭП их деятельности..

Ключевые слова: СМК, сертификация, импортозамещение, востребованное, подтверждение соответствия, стандартизация, аудит, спрос, бракованная продукиия, диаграмма Парето, политика и цели качества, документация, результативность, эффективность, ответственность.

\section{Введение}

Отечественная легкая промышленность переживает не самые лучшие времена, а потребителю предлагается продукция сомнительного качества, попавшая на наши рынки контрафактным и другими нелегальными путями, то есть не имеющая гарантий для покупателей, чтобы воспользоваться своими правами по защите от недобросовестных производителей и поставщиков.

Необходимо реанимировать роль и значение стратегии, ориентированной на качество, так, как только в этом случае руководители предприятий субъективно и объективно вынуждены будут совершенствовать свои производства, используя нанотехнологии и инновационные процессы, чтобы конкурентоспособные и востребованные материалы и изделия в полной мере удовлетворяли потребности отечественных потребителей. При этом обосновано утверждение, что потребление отечественных материалов и изделий регулируется рынком. В этом случае требования рынка должны диктоваться производителям на необходимость в повышении роли государства и потребителей на формирование устойчивого спроса на отечественные материалы и изделия, а именно: поддерживать ассортимент товаров, регулируя его федеральными, региональными и муниципальными заказами; стимулировать стабильность цен; повышать потребительскую способность и постепенно улучшать их качество. 


\begin{tabular}{|c|c|c|c|c|c|c|}
\hline \multirow{4}{*}{ Impact Factor: } & ISRA (India) & $=3.117$ & SIS (USA) & $=0.912$ & ICV (Poland) & $=6.630$ \\
\hline & ISI (Dubai, UAE & $=0.829$ & РИНЦ (Russia & $=0.156$ & PIF (India) & $=1.940$ \\
\hline & GIF (Australia) & $=0.564$ & ESJI (KZ) & $=8.716$ & IBI (India) & $=4.260$ \\
\hline & JIF & $=1.500$ & SJIF (Morocco & $=5.667$ & OAJI (USA) & $=0.350$ \\
\hline
\end{tabular}

Реализация этих задач создаст основу для того, чтобы потребитель осознал необходимость платить за преимущества качественных материалов и изделий, а производитель осознать, что повышение качества материалов и изделий не может быть связанно только с ростом цен, но и за счет технических инноваций, направленных на применение новых технологических и инженерных решений, в том числе совершать революцию качества или через качество рекламы, или через качество реальное.

Сегодня, а тем более завтра важна реализация одного из определяющего принципа эффективности производства - производитель изготавливает именно то, что нужно потребителю в ассортименте, создающим основу для удовлетворения спроса.

Не менее важно понимать роль и значение качественной деятельности, то есть насколько руководители прониклись в сущность вещей, научились управлять вещами, изменять их свойства (ассортимент), форму, заставляя служить человеку без существенного ущерба природе, на благо и во имя человека, то есть в соответствии с требованиями Ф3 $« \mathrm{O}$ техническом регулировании».

О необходимости проведения грамотной промышленной политики в последнее время говорят и политические лидеры, и правительство. Однако если внимательно рассмотреть нормативные, методические документы по структурной перестройке промышленности, то появляется мысль, не наступаем ли мы здесь на те же грабли, на которые наступали все годы реформ, а именно: не заботились о своём производителе.

Специалист в области качества с мировым именем Э. Деминг, который в свое время был научным консультантом правительства Японии и выводил Японию из экономического кризиса, в своей книге «Выход из кризиса» говорит: «... управление бумажными деньгами, а не долговременной стратегией производства - путь в бездну».

По поводу, нужно ли государству проводить промышленную политику, можно привести высказывание выдающегося экономиста прошлого Адама Смита, который 200 лет назад заложил основы научного анализа рыночной экономики. О роли государства он говорил: «... только оно может в интересах нации ограничивать алчность монополистов, авантюризм банкиров и эгоизм торговцев». Точнее не скажешь.

Каковы сегодня результаты экономической деятельности, каковы достижения в этой сфере? Рост золотовалютных запасов, снижение инфляции, профицит бюджета и другие финансово-экономические достижения. А что, разве это является конечным результатом государственного управления, а не количество и качество товаров и услуг, реализуемых на внутреннем и внешнем рынках и не платежеспособность населения приобретать эти товары и услуги? И, в конечном счете, не качество жизни населения страны?

Поэтому вполне закономерно сегодня ставится задача для всех уровней исполнительной и законодательной властей - повышение качества жизни граждан России.

Проведем укрупненно факторный анализ проблемы «качество жизни». Качество жизни граждан зависит от качества потребляемых товаров и услуг в полном диапазоне - от рождения до ритуальных услуг, а также от платежеспособности граждан, которая позволяет приобретать качественные товары и услуги. Названные два фактора (качество и платежеспособность) зависят от состояния экономики страны, которая в свою очередь зависит от эффективности работы предприятий различных отраслей экономики, в том числе и легкой промышленности. Эффективность же работы предприятий зависит от состояния менеджмента, от уровня применения современных методов менеджмента, от реализации требований качества производства.

Проблемы повышения качества, конкурентоспособности материалов и изделий на современном этапе развития российской экономики приобретают все большее значение. Как показывает опыт передовых стран, которые в свое время выходили из подобных кризисов (США в 30-х годах, Япония, Германия - в послевоенный период, позднее - Южная Корея и некоторые другие страны), во всех случаях в основу проведения промышленной политики и подъема экономики была положена стратегия по повышению качества, конкурентоспособности продукции, которая была бы способна завоевать как внутренний, так и внешний рынки сбыта. Все же остальные составляющие реформы экономические, финансово-кредитные, административные были подчинены этой основной цели.

Положительные изменения качества товаров предполагают качественные сдвиги в технике, технологии, организации и управлении производством. Производство должно совершенствоваться, что не означает становиться более затратным.

Абсолютно верно было обращено внимание на одно, обычно ускользающее в проблемной суете, явление - историчность экономики. Такой, какой ее воспринимают сейчас, экономика была не всегда и навсегда не останется. Экономическая жизнь изменяется во времени, что заставляет настраиваться на ее изменяющееся бытие. Современная экономика построена на рыночном фундаменте и законы рынка диктуют ей свои 


\begin{tabular}{|c|c|c|c|c|c|c|}
\hline \multirow{4}{*}{ Impact Factor: } & ISRA (India) & $=3.117$ & SIS (USA) & $=0.912$ & ICV (Poland) & $=6.630$ \\
\hline & ISI (Dubai, UAE & $=0.829$ & РИНЦ (Russia & $=0.156$ & PIF (India) & $=1.940$ \\
\hline & GIF (Australia) & $=0.564$ & ESJI (KZ) & $=8.716$ & IBI (India) & $=4.260$ \\
\hline & JIF & $=1.500$ & SJIF (Morocco & $=5.667$ & OAJI (USA) & $=0.350$ \\
\hline
\end{tabular}

правила. На первом плане прибыль, конкуренция, эффективность, единоначалие. Долго ли так будет продолжаться? Аналитики утверждают, что уже нарастают симптомы нового экономического порядка. Очередной виток экономической спирали также закрутится вокруг рыночного стержня, но значение рынка не останется тотальным. Приоритет рыночной конкуренции, агрессивно вытесняющей на обочину «социалку», не совместим с перспективой экономического развития, подтверждением чего служит устойчивое стремление социал-демократии на Западе развернуть экономику фронтом на социальное обеспечение, справедливое распределение прибыли. Новую экономику именуют временно «рачительной». Она требует гуманизации не только в распределении национального богатства. Гуманизируется и само производство, включая систему управления. Нынешний принцип: «выживает сильнейший, наиболее приспособленный», сменит «социальнопроизводственное партнерство - управляющий и изготовитель сделаются членами одной команды. Массовое производство уступит место организации, соответствующей реализации принципа - «производитель изготавливает именно то, что нужно потребителю». «Рачительная» экономика будет ориентирована на ресурсосберегающие технологии и экологичность производства. Она потребовала нового взгляда на коренные понятия.

И потому должна измениться и философия качества. Надо быть готовым к грядущим событиям.

Качеству «на роду написано» быть во все времена в эпицентре и научных и дилетантских размышлений. Проблема обеспечения качества деятельности не просто универсально актуальная, она - стратегическая. Дилемма в отношении к качеству разумна лишь в пределах противопоставления соотношения действий «непосредственных» и «опосредованных». Высказывания «это все о нем», обязано происхождением качеству. «Забыть» о проблеме качества можно исключительно потому, что всякая плодоносная и светоносная деятельность направлена в конечном счете на совершенствование качества. Качество или «на уме», или «подразумевается». Из соотношения в динамике этих проекций проблемы качества в творческом мышлении выстраиваются в соответствующий график, отражающий актуальность и рентабельность деятельности, направленной на развитие производства.

Наиболее существенный и глобальный характер имеют международные стандарты по менеджменту качества. Применение в них современных методов позволяет решать не только проблему повышения качества, но и проблему экономичности, и проблему производительности. То есть сегодня понятие «менеджмент качества» переходит в понятие «качество менеджмента».

Таким образом, решение задачи повышения эффективности и конкурентности экономики, а в конечном счете и качества жизни, невозможно без осуществления продуманной и грамотной промышленной политики, в которой инновации и качество должны стать приоритетной задачей.

Результаты исследований, проведенные по программе развития в $\mathrm{OOH}$, позволили измерить долю «человеческого фактора» в национальном и общемировом богатстве: $65 \%$ богатства мирового сообщества составляет вклад человеческого потенциала и только треть мирового богатства приходится на природные ресурсы и производственную структуру. Стратегия, ориентированная на качество, несомненно способствует возрастанию и самой роли субъективного фактора в развитии производства, и более полному всестороннему удовлетворению самих человеческих потребностей. Стремление «жить по разумным потребностям», так же, как и необходимость «работать по возможностям», вместе с коммунистическим идеалом никто отменить открыто и официально не рискнул, понимая абсурдность отрицания сущностных сил человека. В «горячем» состоянии проблему качества устойчиво поддерживают и внутренние силы активного сознания, и внешние жизненные факторы. Высшая функция сознания познавательная.

Считается, что, познавая природу, открывается ее качество, состояние качества, уровни качества, воплощая новые знания в производство. Пост классическая экономическая мысль сместила качество в сторону потребления, пытаясь придать производству «человеческое лицо»- человек отчуждает себя в процессе производства, но мера эта вынужденная и в системном понимании - временная, условная. Труд - своего рода «страшные котлы», которые нужно было преодолеть Ване-дурачку, чтобы превратиться в Ивана-царевича.

И здесь абсолютно оправдано считается, что главное в производстве - результат, а не процесс. Потребление регулирует рынок. Следовательно, требования рынка должны доминировать в производстве. Задача общества - всемирно способствовать развитию спроса на рынке: поддерживать ассортимент товаров, стимулировать стабильность цен, повышать покупательную способность, улучшать качество товаров. Э. Деминг, называя «сеть смертельных болезней» современного производства, на первое место ставит «планирование производства, не ориентированное на такие товары и услуги, на которые проявляет спрос рынок». Попробуйте ему возразить. Производство при переходе от 


\begin{tabular}{|c|c|c|c|c|c|c|}
\hline \multirow{4}{*}{ Impact Factor: } & ISRA (India) & $=3.117$ & SIS (USA) & $=0.912$ & ICV (Poland) & $=6.630$ \\
\hline & ISI (Dubai, UAE & $=0.829$ & РИНЦ (Russia & $=0.156$ & PIF (India) & $=1.940$ \\
\hline & GIF (Australia) & $=0.564$ & ESJI (KZ) & $=8.716$ & IBI (India) & $=4.260$ \\
\hline & JIF & $=1.500$ & SJIF (Morocco & $=5.667$ & OAJI (USA) & $=0.350$ \\
\hline
\end{tabular}

индустриального к постиндустриальному обществу массового потребления мыслится в качестве функции рынка.

И авторы наполняют эти свойства качества критериями, а именно:

- идеология качества - перспектива развития производства;

- управление качеством - это комплексный подход к решению проблемы качества;

- мода и техническое регулирование составляющие качества изготавливаемой обуви;

- системы качества «УПОРЯДОЧИВАНИЕ/5

$\mathrm{S} »$ и «ТРИ «НЕ» - не только основа стабильности и безопасности производства, но и гарантия качества;

- качество на рынке - это парадигма формирования производства удовлетворяющего потребности рынка;

- реклама всегда на службе качества;

- экскурс в прошлое как гарантия качества в будущем;

- модель оценки качества продукции - это приоритеты производстве;

- прогнозирование затрат на качество при разработке нового ассортимента обуви - залог ее востребованности и ее конкурентоспособности;

- методика деловой визуальной оценки изделия - средство оценки эффективности качества;

- повышение качества и конкурентоспособности отечественной спецобуви;

- о показателях оценки качества обуви - как инструмент для формирования востребованной продукции;

- качество и рынок: брак по расчёту и это бесспорно;

- стабильность работы предприятий - гарант качества выпускаемой ими обуви;

- все эти аспекты вместе и обеспечивают революцию качества, гарантирующие производителю стабильный успех на рынке с не стабильным спросом.

Представляемая Вашему вниманию работа плод совместных размышлений над актуальными проблемами совершенствования деятельности важной отрасли общественного хозяйства ведущих российских и зарубежных специалистов. $\mathrm{У}$ коллективно выполненной монографии всегда есть преимущество перед индивидуальной формой творчества. Отдельно взятый автор, сколь бы сведущ и авторитетен он не был, вынужден характером обстоятельств объяснять не только свою точку зрения на исследуемую проблему, но рассказывать о том, как «видят» эту проблему коллеги, излагать чужой взгляд на порядок вещей, превращаться в процессе объявленной дискуссии в своих оппонентов. Такая трансформация, несмотря на всю её условность, не столь уж безобидная для объективности в понимании. Даже такой прекрасный мыслитель, как Г. Гегель, грешил, вольно или невольно подставляя оппонентов, чтобы удобнее было их критиковать. Настоящий труд представляет оригинальный авторский подход и открывает возможность узнать самое значимое из первых рук, без посредников, которые нередко омрачают творческие отношения.

Качеству «на роду написано» быть во все времена в эпицентре и научных, и дилетантских размышлений. Проблема обеспечения качества деятельности не просто универсально актуальная, она - стратегическая. Дилемма в отношении к качеству разумна лишь в пределах противопоставления соотношения действий «непосредственных» и «опосредованных». Высказывания «это все о нем», обязано происхождением качеству. «Забыть» о проблеме качества можно исключительно потому, что всякая плодоносная и светоносная деятельность направлена в конечном счете на совершенствование качества: качество или «на уме», или «подразумевается». Из соотношения в динамике этих проекций проблемы качества в творческом мышлении выстраивается соответствующий график, отражающий актуальность и рентабельность деятельности, направленной на развитие производства.

Реанимировать роль и значение стратегии, ориентированной на качество, так, как только в этом случае руководители предприятий субъективно и объективно вынуждены будут совершенствовать свои производства, используя нанотехнологии и инновационные процессы, чтобы конкурентоспособные и востребованные материалы и изделия в полной мере удовлетворяли потребности отечественных потребителей. При этом обосновано утверждение авторов, что потребление отечественных материалов и изделий регулируется рынком. В этом случае требования рынка должны формировать в производстве, и авторы подтверждают эту ситуацию, обращая внимание на роль государства и потребителей на формирование устойчивого спроса на отечественные материалы и изделия, а именно: поддерживать ассортимент товаров, регулируя его федеральными, региональными и муниципальными заказами; стимулировать стабильность цен; повышать потребительскую способность и постепенно улучшать качество товаров. Реализация этих задач создаст основу для того, чтобы потребитель осознал необходимость платить за преимущества качественных материалов и изделий, а производитель понял, что повышение качества материалов и изделий не может быть связано только с ростом цен, оно может происходить и за счет технических 


\begin{tabular}{|c|c|c|c|c|c|c|}
\hline \multirow{4}{*}{ Impact Factor: } & ISRA (India) & $=3.117$ & SIS (USA) & $=0.912$ & ICV (Poland) & $=6.630$ \\
\hline & ISI (Dubai, UAE & $=0.829$ & РИНЦ (Russia & $=0.156$ & PIF (India) & $=1.940$ \\
\hline & GIF (Australia) & $=0.564$ & ESJI (KZ) & $=8.716$ & IBI (India) & $=4.260$ \\
\hline & JIF & $=1.500$ & SJIF (Morocco & $=5.667$ & OAJI (USA) & $=0.350$ \\
\hline
\end{tabular}

инноваций, направленных на применение новых технологических и инженерных решений.

Сегодня, а тем более завтра важна реализация одного из определяющих принципов эффективности производства - производитель изготавливает именно то, что нужно потребителю.

Не менее важно понимать роль и значение качественной деятельности, то есть насколько руководители прониклись в сущность вещей, научились управлять вещами, изменять их свойства (ассортимент), форму, заставляя служить человеку без существенного ущерба природе, на благо и во имя человека.

Качество деятельности - финишный критерий ее индивидуального, коллективного и национального статуса. Именно в качестве аккумулируется энергия созидания. Качество деятельности свидетельствует, насколько мы проникли в сущность вещей, научились управлять вещами, изменять их свойства, форму, заставляя служить человеку, без существенного ущерба природе. Качество позволяет в новых ракурсах увидеть и самого человека, воздать должное его таланту, воле, профессионализму. Исследования, проведенные по программе развития в $\mathrm{OOH}$, позволили измерить долю «человеческого фактора» в национальном и общемировом богатстве: $65 \%$ богатства мирового сообщества составляет вклад человеческого потенциала и только треть мирового богатства приходится на природные ресурсы и производственную структуру. Стратегия, ориентированная на качество, несомненно способствует возрастанию и самой роли субъективного фактора в развитии производства, и более полному всестороннему удовлетворению самих человеческих потребностей. Стремление «жить по разумным потребностям» так же, как и необходимость «работать по возможностям», вместе с коммунистическим идеалом никто отменить открыто и официально не рискнул, понимая абсурдность отрицания сущностных сил человека. В «горячем» состоянии проблему качества устойчиво поддерживают и внутренние силы активного сознания, и внешние жизненные факторы. Высшая функция сознания познавательная. Познавая природу, мы открываем ее качества, состояние качества, уровни качества, воплощая новые знания в производство. Классическая политэкономия (А. Смит, Д. Риккардо, К. Маркс, Дж. Милль) сконцентрировала проблемы качества в производстве. Пост классическая экономическая мысль сместила качество в сторону потребления, пытаясь придать производству «человеческое лицо»- человек отчуждает себя в процессе производства, но мера эта вынужденная и в системном понимании - временная, условная. Главное в производстве - результат, а не процесс.
Потребление регулирует рынок. Следовательно, требования рынка должны доминировать в производстве. Задача общества - всемирно способствовать развитию спроса на рынке: поддерживать ассортимент товаров, стимулировать стабильность цен, повышать покупательную способность, улучшать качество товаров. Э. Деминг, называя «сеть смертельных болезней» современного производства, на первое место ставит «планирование производства, не ориентированное на такие товары и услуги, на которые проявляет спрос рынок». Попробуйте ему возразить. Производство при переходе от индустриального к постиндустриальному обществу массового потребления мыслится в качестве функции рынка.

Динамика развития рынка в последние десятилетия прошлого столетия и в начале третьего тысячелетия неизменно показывает усиление интереса потребительского спроса к качеству товара. При всех экономических, социальных и политических издержках человечество богатеет и богатства распределяются неравномерно. Финансы, как и ранее, концентрируются в определенных регионах, впрочем, так же, как и премьеры современного производства. Курс на качество товаров аналитиками прогнозируется уверенно и повсеместно. Потребитель осознал необходимость платить за преимущество качественных услуг и изделий. Очередь за производителем, который должен замкнуть в уме «жадность» и «смертный грех», чтобы сжечь алчность. Виднейшие экономисты однозначно заявляют, что повышение качества товаров не связано причинно-следственно с ростом цены. Положительные изменения качества товаров предполагают качественные сдвиги в технике, технологии, организации и управлении производством. Производство должно совершенствоваться, что не означает становиться более затратным.

И ещё хотелось бы обратить внимание на одно, обычно ускользающее в проблемной суете, явление - историчность экономики. Такой, какой мы ее воспринимаем сейчас, экономика была не всегда и навсегда не останется. Экономическая жизнь изменяется во времени, что заставляет нас настраиваться не ее изменяющееся бытие. Современная экономика построена на рыночном фундаменте, и законы рынка диктуют ей свои правила. На первом плане прибыль, конкуренция, эффективность, единоначалие. Долго ли так будет продолжаться? Аналитики утверждают, что уже нарастают симптомы нового экономического порядка. Очередной виток экономической спирали также закрутится вокруг рыночного стержня, но значение рынка не останется тотальным. Приоритет рыночной конкуренции, 


\begin{tabular}{|c|c|c|c|c|c|c|}
\hline \multirow{4}{*}{ Impact Factor: } & ISRA (India) & $=3.117$ & SIS (USA) & $=0.912$ & ICV (Poland) & $=6.630$ \\
\hline & ISI (Dubai, UAE & $=0.829$ & РИНЦ (Russia & $=0.156$ & PIF (India) & $=1.940$ \\
\hline & GIF (Australia) & $=0.564$ & ESJI (KZ) & $=8.716$ & IBI (India) & $=4.260$ \\
\hline & JIF & $=1.500$ & SJIF (Morocco & $=5.667$ & OAJI (USA) & $=0.350$ \\
\hline
\end{tabular}

агрессивно вытесняющей на обочину «социалку», не совместим с перспективой экономического развития, подтверждением чего служит устойчивое стремление социал-демократии на Западе развернуть экономику фронтом на социальное обеспечение, справедливое распределение прибыли. Новую экономику именуют временно «рачительной». Она требует гуманизации не только в распределении национального богатства. Гуманизируется и само производство, включая систему управления. Нынешний принцип: «выживает сильнейший, наиболее приспособленный», сменит «социальнопроизводственное партнерство» - управляющий и изготовитель сделаются членами одной команды. Массовое производство уступит место организации, соответствующей реализации принципа - «производитель изготавливает именно то, что нужно потребителю». «Рачительная» экономика будет ориентирована на ресурсосберегающие технологии и экологичность производства. Она потребует нового взгляда на коренные понятия. Изменится и философия качества. Надо быть готовым к грядущим событиям. В меру своей компетенции и интересов авторы попытались поделиться с Вами, дорогой читатель, своими мыслями, доверили Вам свои суждения о прошлом, настоящем и будущем дела, которому посвятили жизнь, свои исследования, чтобы ответить на главный вопрос: что главенствует в качестве - реклама или производитель и объединит их революция в качестве или сделать это будет невозможно? Но жизнь рассудит и тех и других.

\section{Основная часть}

Характер новой конкуренции в современной мировой экономике, обусловленный процессами глобализации, ставит перед производителями высокие требования к повышению конкурентоспособности товаров и предприятий. Повышение конкурентоспособности предприятий и отраслей является одним из важнейших направлений реального экономического роста, как в России, так и в регионах ЮФО и СКФО, что отражено в программном документе, а именно: в стратегии развития легкой промышленности России на период до 2025 г.

$$
\text { В этой связи проблема }
$$
конкурентоспособности отечественной обуви требует разработки концептуальных основ теоретико-методологических и практических рекомендаций, адекватных предстоящим изменениям в организационно-экономическом механизме функционирования всего промышленного комплекса страны.

В современных условиях рыночных отношений, конкурентной среды и непосредственного взаимодействия российских и зарубежных производителей решение проблемы сочетания государственных и рыночных механизмов управления конкурентоспособностью становится стратегическим ресурсом экономики регионов ЮФО и СКФО. В мировой экономике место ценовой конкурентоспособности заняла конкурентоспособность уровней качества, которая повысит свою актуальность с вхождением России в ВТО. Возрастание фактора качества результатов деятельности производства отечественной обуви в стратегии конкурентной борьбы на мировых рынках является долгосрочной тенденцией

В России, как и в большинстве российских региональных образований, есть все необходимые условия для развития производства в общенациональных интересах. Если где-то чегото недостаточно, то это не служит основанием для рецессии и спада.

В середине 2010-х страна оказалась в экономической ситуации подобной концу 1920-х - началу 1930-х годов. Тогда встал вопрос: быть или не быть новому общественному устройству, желанному народу (ибо «избранные» всегда приспосабливаются к любой ситуации). Ответ не был спрятан в лабиринте, и Л.М. Кагановичу не нужна была нить Ариадны, чтобы добраться в поисках ключа решения проблемы к тайному источнику. Ему нужно было благословение вождя. И И.В. Сталин согласился с тем, что «кадры решают всё». От себя уточним «профессионально подготовленные и политически ответственные за результат». Пояснение важное, т.к. демократические преобразования в России чудесным образом сняли первым делом профессиональную ответственность за очевидные дефекты в политике.

Политика всеми и всегда понималась как деятельность в интересах государства. Политическая ответственность в демократически обустроенном обществе - высшая мера выражения профессионализма. Невыполнение политических обещаний и заявлений свидетельствует либо о неспособности заниматься политикой, либо использовании политического управления в частных интересах. 85 лет назад очевидное для сознания и было таковым на практике. Напрасно, говоря о жестокости И.В. Сталина, забывают о том, что каждый просчет в политике отражается на положении народа, а не политиков, управленцев, консультантов, советников.

В интересах перестройки экономики на путь увеличения в товарном производстве доли добавленного капитала - по сути дела современной индустриализации, начинать надо не с экономических и не с научно-технических 


\begin{tabular}{|c|c|c|c|c|c|c|}
\hline \multirow{4}{*}{ Impact Factor: } & ISRA (India) & $=3.117$ & SIS (USA) & $=0.912$ & ICV (Poland) & $=6.630$ \\
\hline & ISI (Dubai, UAE & $=0.829$ & РИНЦ (Russia & $=0.156$ & PIF (India) & $=1.940$ \\
\hline & GIF (Australia) & $=0.564$ & ESJI (KZ) & $=8.716$ & IBI (India) & $=4.260$ \\
\hline & JIF & $=1.500$ & SJIF (Morocco & $=5.667$ & OAJI (USA) & $=0.350$ \\
\hline
\end{tabular}

действий - с политического ренессанса. Разумеется, новое время требует иных инструментов, отличных от мер второй половины 1930-х годов, но суть должна быть инвариантна. Политическая эффективность - высший критерий профессионализма. Толковать данный вывод лучше от противного. Не дотянула фактическая реальность до заявленных перемен - отставка управленцев с последующей общественной характеристикой в зависимости от конкретных условий и размеров нестыковки.

В советские времена был распространен партийный сленг - «поставить в ответственное положение»! Никто толком не знал, что и как это надо делать, но все знали, если не выполнить, будет плохо. У нас же почему-то ответственность переложили на рынок. Ответственность за выполнение конкретных политических направлений, теряя персонифицированный вид, перестает быть ответственностью. Дума у нас ни за что не отвечает. Правительство отвечает перед Президентом и Думой. Персональную ответственность несет перед народом исключительно Президент. Отсюда и единственный достойный рейтинг народного опроса. Бесспорно, помогла Президенту его патриотическая политика - последовательная, активная. Но, создается впечатление, что основным фактором, пусть и не очевидным, популярности Президента в отличие от всех, наделенных властью, является его практическая дееспособность, мотивированная высокой политической ответственностью.

К сожалению, пока узлы, завязанные хозяйственной недееспособностью и безнаказанностью, будет развязывать Президент, а ответственные за решение проблем, стоящих перед обществом, продолжат откровенно тянуть время, прикрываясь неопределенностью толкования модернизации, наша генеральная задача «слезть с сырьевой зависимости» - $55 \%$ налоговых поступлений, решена не будет.

Персонификация ответственности не означает поиск того, кто за всё отвечает. Персонификация подразумевает делегирование ответственности за получение искомого результата. Здесь существенно осознать, что «команда» - не компания единомышленников, коллег, партнеров; «команда» - цепочка ответственных, обусловленная спецификой объекта и решаемых проблем его модернизации. Ответственность за результат не должна размазаться в недрах команды. Ответственность даже за командный результат всегда имеет персональное выражение, которое в упор не хотят признавать наши высокие управленцы. Именно данным стремлением - «спихнуть» всё на специфику объекта управления, непредсказуемость спроса, волатильность валюты, непонятность изменения тарифов и т.П., можно объяснить тот напор «сверху», с помощью которого нам доказывают, что менеджмент профессиональное направление, а не надстройка над предметным своеобразием и системным положением определенного производства.

Любопытный факт, правда, не из истории «легкой» промышленности. Д.И. Менделеев в начале XX века получил задание Правительства разобраться с секретом модернизации пороха в Германии. Не имея прямого доступа к немецкой технологии, ученый-химик запросил мониторинг перемещения грузовых железнодорожных составов в тех местах, где производится порох с отслеживанием начала и конца маршрутов. На базе полученных сведений он расшифровал немецкий рецепт и разработал рекомендации для Российского Правительства. Был бы на его месте чистый экономист, современный топ-менеджер, результат получился бы стопроцентно иным. Он завяз бы в статистически-финансовых расчетах расходов-доходов, уйдя от политической и научно-технической составляющих. Самая серьезная методологическая ошибка экономическую политику сводить к экономическому анализу.

Экономическая наука возникла и развивалась в контексте с политикой, как политическая экономия. Сегодня же экономисты в политике руководствуются не политической экономией, а экономикой в политике. Вместо инвестирования в развитие производства прячут деньги в иностранных банках, сокращают финансирование на образование и самообразование, увеличивают число бедных, не индексируют пенсии, отказывают в помощи фермерам и т.п. «Маниловых» девяностых сменили «плюшкины» десятых.

Основное и инвариантное превосходство России заключено в географическом положении, сочетающемся с отсутствием опасности перенаселения нашего пространства за счет естественного прироста. У нас естественный и солидный запас прочности на века. Вместо того чтобы прессинговать прошлое за неразумность в политике и экономике, следовало бы воздать по действительным заслугам нашим предкам, сумевшим собрать Россию и народы вокруг России. Беспокоит не столько сам спад производства, растранжиривание того, в чем исторически проявлялась его национальная специфика, народных традиций, сколько возможность утраты трудового таланта народов России, тревогу вызывает системная неэффективность экономической политики.

Прогресс не бывает без отступлений, замедлений в движении, рецессий. Политика призвана активными, целенаправленными действиями помочь преодолеть возникающие в 


\begin{tabular}{|c|c|c|c|c|c|c|}
\hline \multirow{4}{*}{ Impact Factor: } & ISRA (India) & $=3.117$ & SIS (USA) & $=0.912$ & ICV (Poland) & $=6.630$ \\
\hline & ISI (Dubai, UAE & $=0.829$ & РИНЦ (Russia & $=0.156$ & PIF (India) & $=1.940$ \\
\hline & GIF (Australia) & $=0.564$ & ESJI (KZ) & $=8.716$ & IBI (India) & $=4.260$ \\
\hline & JIF & $=1.500$ & SJIF (Morocco & $=5.667$ & OAJI (USA) & $=0.350$ \\
\hline
\end{tabular}

развитии препятствия. Политики должны опережать экономическое движение и направлять его, стимулировать внутренние экономические факторы политическими рычагами, расчищать экономические пути к эффективному производству. Вместо этого политики продолжают привязывать планы развития к цене на нефть, рублевому размеру европейской и американской валюты, ссылаясь на интеграционные тенденции в мире и глобализацию.

Интеграция транснациональных отношений - объективная реальность, но при всей своей объективности она не отрицает специфики национального экономического продвижения. Более того, интеграция объективно призвана способствовать национальному развитию. Почему у нас тогда не получается, как должно быть? Вопрос этот возникает из логического сравнения политики в сфере укрепления обороноспособности, восстановления международного авторитета страны в тяжелейших обстоятельствах формирования новой мировой архитектоники с тем, что из года в год россияне наблюдают и в полной мере ощущают на себе в сфере остальной экономики, - у нас случайно не два правительства? Второе «жмёт на газ и тормозит» одновременно.

Затяжная рецессия в российской экономике имеет: два способа объяснения. Первый - народ потерял способность хорошо работать, растратил «человеческий капитал», второй - управляющие беспомощны. Средства массовой информации уверяют, что политики знают своё дело, держат события под контролем, принимают необходимые меры и обещают перемены к лучшему в ближайшей перспективе. Стало быть, причина в плохой работе исполнителей и неблагоприятной мировой конъюнктуре.

Насколько же нужно быть наивным, чтобы, планируя экономическую политику, опираться на искренность, бескорыстность, сочувствие конкурентов? Президент РФ давно заявил, что наши западные партнеры не хотят усиления России, им нужна послушная Россия, типа Балтийских республик, ранее входивших в состав CССР. Не хотелось печалить политиков, ответственных за экономику, но, следуя Аристотелю, вынуждены констатировать: «Друзья на Востоке тоже себе на уме» - в смысле «Платон мне друг, но истина дороже». Они нам будут помогать по мере выгоды себе от такой помощи.

Пора понять, что все экономические и политические союзы в современном мировом пространстве - это попытка добиться национального выигрыша в среде транснациональных отношений, т.е. на партнеров можно рассчитывать, пока им это сотрудничество выгодно. Из чего следует вывод - лицом стоять необходимо к своей экономике. Только так, пусть и с большим напряжением, удастся решить свои проблемы. Нет, к примеру, таких объективных причин, которые оправдали бы спад производства в легкой промышленности на протяжении четверти века.

Легкая промышленность, тесно связанная с сельским хозяйством, действительно зависима от работы последнего. Только к подобному взаимодействию нужно подходить исторически конкретно, опираясь на научно-диалектический анализ. Имеются старые метеорасчеты, показывающие, что из 10 календарных лет в России 5 неблагоприятных для развития сельскохозяйственного производства (2+3 и $3+2)$. При определении «пятилетки» как меры планирования опирались на эту закономерность.

Проблемы сельского хозяйства и легкой промышленности не в их специфике, они всегда были политическими. В США, Европе у фермеров немало наших проблем. Различие же в том, что там фермер - национальная проблем среди важнейших, основных. Её рассмотрение актуально для существования политиков. От того как политика способствует разрешению, оценивается публично место политика. Фермер и политик связаны экономической политикой. Они балансируют на одном натянутом экономическим напряжением «канате» жизнеспособности.

Ничего похожего в России нет. Вспомним историю последних министров сельского хозяйства. В СССР существовало Министерство легкой промышленности, что подчеркивало значимость отрасли. Что мешает в условиях импортозамещения и деклараций о важности развивать собственное производство восстановить равноправие в промышленном управлении. «Ситцевый край» без легкой промышленности все равно, что родная природа без березовых рощ или лирическая поэзия без творчества С. Есенина.

Реформаторов 1990-х судьба Отечества и отечественного промышленного своеобразия меньше всего волновала. Они выстраивали бизнес на легкости получения максимальной прибыли и размещали моржу вдали от земли предков. Легкая промышленность традиционно была тяжелой проблемой для управления. Управленцам надо быть, прежде всего, патриотами, иначе легкую промышленность не поднять. Необходимо также понимание национальной важности «длинных денег». Компенсацией трудностей стала бы устойчивость спроса.

В чем суть неэффективности политики в экономике конца прошлого и начала нового века? Это вопрос №1, причем речь идет не столько о том, кто виноват. Нас интересует суть политической парадигмы, разработанной теми, 


\begin{tabular}{|c|c|c|c|c|c|c|}
\hline \multirow{4}{*}{ Impact Factor: } & ISRA (India) & $=3.117$ & SIS (USA) & $=0.912$ & ICV (Poland) & $=6.630$ \\
\hline & ISI (Dubai, UAE & $=0.829$ & РИНЦ (Russia) & $=0.156$ & PIF (India) & $=1.940$ \\
\hline & GIF (Australia) & $=0.564$ & ESJI (KZ) & $=8.716$ & IBI (India) & $=4.260$ \\
\hline & JIF & $=1.500$ & SJIF (Morocco & $=5.667$ & OAJI (USA) & $=0.350$ \\
\hline
\end{tabular}

кто оказался «у руля». Вопрос №2 - что следует изменять и как, по-видимому, надо это сделать, чтобы поднять национальную промышленность, производство одежды, обуви, кожгалантереи, текстиля, фурнитуры не в последнюю очередь?

Ответ на вопрос №1 простой - никто и не собирался разрабатывать парадигму экономической политики, нацеленной на коренное преобразование базиса. Способ реформирования (не без помощи со стороны) решили выбрать из готовых образцов. За модель предлагалось взять шведский опыт, польскую «шоковую терапию», реформы в Португалии, Аргентине.

Политика не делается в зависимости от состояния чувств. Нравится или не нравится уровень бытового восприятия мира. С таким подходом на «политической кухне» вредно находиться. Экономическая политика не подходит под оценки «хорошая» или «плохая», «эффективная» или «неэффективная». Она имеет право называться либо «полезной», либо «вредной». Слишком велика цена такой политики, соответственно и ответственность не ограничивается профессиональной формой. Политика есть политика. Антиполитично и непрофессионально делать из политики источник собственного дохода.

Какой бы экономическая ситуация не складывалась, крайне опасно абсолютизировать значение экономических критериев, наделять их свойством всеобщости. Ф. Энгельс резко высказывался против попыток свести учение К. Маркса об общественном развитии к «экономическому материализму», «экономическому детерминизму». Экономический базис - основа социальной организации, но никак не системообразующий фактор её совершенствования.

Общество - система человеческих отношений, осуществляющихся в динамике экономической деятельности. Деятельность средство социальной жизни людей. Деятельность, обусловливающая необходимость разного рода отношений - способ проявления и развития человека. Отношения призваны обеспечить такое человеческое развитие. Про то, что форму собственности нужно изменять, в конце XX века не говорили лишь немые, а вот о том, что отношения, рождающиеся формой собственности, тянут за собой распределение произведенного продукта, либо его денежного эквивалента, что обмен нельзя полностью доверять рынку, контрольные функции нужно сохранять за государством, переустроенным демократически, что в извращенно-бюрократическом виде государство остается генератором коррупции, старались умолчать, понимая деликатность реформирования собственности.

Большинству населения нет актуальности в том, кто собственник, далеко не все хотят примерять на себя функции собственника крутиться, вертеться, бороться, рисковать. Распределение же напротив, касается всех, и бедных, и небедных.

$$
\text { Самая }
$$

экономических

удовлетворения национального сложная
реформ
в обществ

в обществе продукта.

составляющая достижение удовлетворения, а не от формы собственности зависит здоровье общества. И мы подошли к важному заключению - качество реформ оценивается не самими изменениями, а способностью придать общественной жизни черты стабильности.

Интеграция, глобализация - не панацея развития. Они не отменяют конкурентной борьбы, в которой бывают не одни победители. Проигравших больше. Отсюда и актуальность старой истины, смысл которой стал понятным в диалектике. Движение в любых условиях становится самодвижением. Китайцы рационально закрыли себя и выиграли. Победу им обеспечили: восточная осторожность и скептическое отношение к объединению. Они раньше нас сообразили, что интеграция и глобализация являются разновидностями «пирамид» и условно полезные для национального развития. Со стороны могло показаться, что китайские реформаторы отказались от ментальности проклятия: «чтобы жить тебе во время перемен». Изнутри всё выглядело традиционно - политики не предавали резким движением национального масштаба, торопились, но с постоянной привязкой действий к государственному экономическому укладу, реформы в экономике подчиняли традиционным политическим доминантам, не каялись и не старались понравиться. Ни о каких экономических шоках никто всерьез не думал. Финансы как кровеносную систему экономического организма взяли в «ежовые государственные рукавицы», ввели ужесточение за экономические и коррупционные преступления, приравняв многие из них к опасным действиям против государства, не стали придумывать новые партии - обновили имеющуюся, как и прежде особое внимание уделили кадровой политике. Китайцы учли советский партийный опыт «выращивания» кадров, в основе которого лежал принцип поступательности продвижения в зависимости от деловой эффективности и образа жизни.

В семидесятилетней советской истории были единичные случаи, когда в управлении экономикой оказывались случайные люди. Они могли оказаться именно случайно, подтверждая своей исключительностью, дееспособность 


\begin{tabular}{|c|c|c|c|c|c|c|}
\hline \multirow{4}{*}{ Impact Factor: } & ISRA (India) & $=3.117$ & SIS (USA) & $=0.912$ & ICV (Poland) & $=6.630$ \\
\hline & ISI (Dubai, UAE & $=0.829$ & РИНЦ (Russia & $=0.156$ & PIF (India) & $=1.940$ \\
\hline & GIF (Australia) & $=0.564$ & ESJI (KZ) & $=8.716$ & IBI (India) & $=4.260$ \\
\hline & JIF & $=1.500$ & SJIF (Morocco & $=5.667$ & OAJI (USA) & $=0.350$ \\
\hline
\end{tabular}

политической кадровой парадигмы. Принимая во внимание экономические минусы избыточной централизации в управлении народным хозяйством, можно позволить себе следующий тезис - социалистическая экономика советского типа не была рационально выстроенной, но в ней содержался значительный резерв, дававший возможность новым революционерам не повторять старые большевистские приемы помогать одним и грабить других.

Большевики в образе революционеров выглядят при всей одиозности политики национализации собственности в более выгодном свете в сравнении с теми, кто в 1990-е разбазаривал национальное достояние и крайне неохотно меняет свое заинтересованное отношение к происходящему сегодня. Итогом революции 1917 года была индустриализация и подъем легкой промышленности, народных промыслов, результатом контрреволюции 25-летняя депрессия экономики, борьба за существование текстильного, обувного, швейного производства, спад в организации подготовки квалифицированных кадров по всему спектру - от рабочих специальностей до инженерных. В подобных условиях пора отступиться от абстрактных политических идеалов демреформаторов и вплотную разрабатывать «дорожную карту» возрождения легпрома в расчете на то, что кризис подчеркивает актуальность разумности «мозгового штурма» в противоположность «экономическим школам» в тренде. Какой это дорожной «картой» представляется, исходя из исторического опыта $\mathrm{XX}$ века, когда произошли все основные события.

1. В приоритете устойчиво должны быть интересы национального продвижения. О развитии очень хотелось бы сказать, однако его в национальных масштабах сейчас не получить. Нужно «зализывать раны». На сегодня экономически наиболее оптимистическая оценка находится в рамках достижения устойчивой стабилизации экономических показателей. Врачи в подобной ситуации обнадеживают: состояние «стабильно тяжелое». К сожалению, экономику нельзя ввести в «искусственную кому», помогающую преодолеть кризис за счет более экономного расходования жизненных сил. Нас первый пункт «дорожной карты» интересует вот чем. Врачи стремятся мобилизовать жизненный потенциал организма, помочь раскрыть запас воли к жизни. Наша экономика способна бороться за выживание, в ней немало умных, знающих, преданных делу патриотов, правда, с каждым потерянным годом их количество уменьшается. По данным д.э.н., профессора НИУ «Высшая школа экономики» В. Иноземцева - одного из постоянных авторов АиФ, из страны ежегодно уезжают около 400 тыс. человек. Естественно, не все на ПМЖ, кто-то работать по контракту, в поисках временной работы. В первую очередь нужно помочь энергичным людям, зажечь им зеленый свет в конце тоннеля. Рассчитывать на чиновников сложившегося за четверть века типа, уверенных, что над ними висит не меч правосудия, а сейф старшего бюрократа для приема вознаграждения, не приходится. Возможный вариант - ОНФ. Президент РФ регулярно и заинтересованно общается с его активистами. Общение продуктивно.

Академик А.Г. Аганбегян свидетельствовал, что год экономического спада по причине неумного управления требует много больше времени, чтобы восстановить экономику. Действовать на стартовом отрезке надлежит так, чтобы хватило сил финишировать и осталось бы их для очередного этапа. Не следует надеяться и на большие достижения. Чудесных превращений можно ждать в частном предпринимательстве. Здесь вполне способен проявиться случай. В общем процессе роль случая незначительна. Отказываться верить в удачу, тем не менее, неразумно. Есть мнение, что «везет» тем, кто везёт. Удачный расклад возможно индуцировать посредством профессиональной активности, характера, веры в благополучный исход и даже в высшую справедливость. Вера, сопровождающая разум, еще никому не помешала в стремлении творить доброе дело.

Все межгосударственные союзы необходимо рассматривать исключительно в национальных интересах, иначе проиграешь. Экономическое соглашение - это международное условие, которое реально попытаться использовать для собственного продвижения, как на уровне компании, так и отрасли. Однако следует понимать, что если не сумеешь извлечь выгоду из условий договора ты, то её получат твои конкуренты, оказавшиеся более сообразительными. Не исключен и компромиссный вариант, когда прибыль взаимная и временно делится пропорционально участию. Главное знать - соглашение в любой форме конкурентов оставляет конкурентами, оно придает конкуренции цивилизованный вид, ограничивая произвольные действия. За руководителей КНР говорит производство. За 2016 год китайцы пошили около 14 млрд. пар обуви - по 2 пары на каждого жителя Земли. Китайские лидеры поэтому на встречах, при подписании протоколов, малословны. Нашим приходится сложнее - от них в отсутствии аналогичных показателей ждут заверений в дружбе и взаимопомощи. Хорошие, добрососедские, взаимовыгодные отношения являются единственно действительной реальностью прогрессивного движения. Все иное - виртуальная реальность. 


\begin{tabular}{|c|c|c|c|c|c|c|}
\hline \multirow{4}{*}{ Impact Factor: } & ISRA (India) & $=\mathbf{3 . 1 1 7}$ & SIS (USA) & $=0.912$ & ICV (Poland) & $=6.630$ \\
\hline & ISI (Dubai, UAE & $=0.829$ & РИНЦ (Russia & $=0.156$ & PIF (India) & $=1.940$ \\
\hline & GIF (Australia) & $=0.564$ & ESJI (KZ) & $=8.716$ & IBI (India) & $=4.260$ \\
\hline & JIF & $=1.500$ & SJIF (Morocco & $=5.667$ & OAJI (USA) & $=0.350$ \\
\hline
\end{tabular}

2. Ставка на всемерную поддержку легкой промышленности, как и большинство направлений инвестирования государственных средств (финансовых, правовых, политических, гуманитарных), содержит риск, однако в пределах допустимых значений. История проверила Россию и в качестве самостоятельного государства, и в составе СССР на способность создавать разнообразные и качественные товары народного спроса в достаточном количестве. Сильные стороны отечественных товаров легкой промышленности: качество материала, гигиеничность, соответствие национальным эргономическим и климатическим условиям, разнообразие ассортимента.

В России можно производить практически все виды материалов, необходимых для легпрома. Производство отдельных видов сырья ограниченно по объему, что в принципе регулируется научно-техническим прогрессом. Развитие науки и технологии дополнило естественные материалы искусственными, синтетическими. В стране сложились научные школы в рамках сельскохозяйственного производства и легкой промышленности, была создана система специализированного профобразования. Кадры готовили в училищах, техникумах, вузах, часть учебных заведений исчезла в ходе демократических преобразований, но опыт подготовки остался. Его нетрудно реанимировать. Сохранились промышленные центры, предприятия. Как раз в тех местах, где высок процент безработных. Возрождение предприятий легпрома приведет к активизации социокультурной среды, региональных традиций, веры в перспективу у населения. Вернется социальный оптимизм у людей.

В пользу целенаправленности развивать производство товаров, необходимых для удовлетворения физиологических потребностей человека, служат и размеры потребительского рынка. Они гарантируют производству стабильность загруженности заказами на соответствующие товары.

3. По-прежнему высок творческий потенциал специалистов. Он вполне конкурентоспособен. Отечественные художники, модельеры, инженеры, организаторы имеют высокий международный рейтинг. Нередко их больше и лучше знают за рубежом, чем в родной стране. Как все творчески настроенные люди, они стремятся к диверсификации развития производства с учетом специфики рынка, сознают значимость мониторинга интереса и возможностей массового потребителя. Мы ушли от госрегулирования количества, качества, цены произведенной продукции, чем быстро воспользовались случайные для отрасли люди. Те, кто, приватизировав предприятия, понял это как способ поправить личные доходы и стремился выжать максимум маржи, виновны в развале отрасли не меньше своих «старших» партнеров, определявших с помощью бездарно проведенных реформ судьбу народом созданной экономики. Олигархи и олигархический капитализм также явление исторически развивающееся. Ошибочно отвергать социально позитивный смысл их существования. Одно дело олигархи-финансисты, олигархи-медиамагнаты, сколотившие состояния на спекуляции, посредничестве, дикой добычи углеродного сырья, другое - те, кто развивал реальное производство со значительным удельным весом добавленной стоимости, т.е. думал о будущем.

После «Гайдаровского экономического форума» и съезда промышленников (2016г.), олигарх О. Дерипаска высказался весьма политически зрело: «2016 - последний год, когда государство способно будет использовать резервы для помощи производству, со следующего года мы должны начать помогать государству». Есть уверенность, что мнение одного из наиболее деятельных и опытных отечественных олигархов не его эксклюзивный взгляд на взаимодействие государства и хозяйствующих субъектов.

Бежать из России в расчете на будущее - удел тех, кто настроен против России, прячется в «белый пушистый мех» абстрактной демократической идеи о мировом единстве вместе со своей алчностью. На Западе нужны не они, там востребованы их финансы - не столь впечатляющие по западным меркам, как в разграбленном отечестве, и «антипутинские взгляды»

История России богата примерами умной, патриотической экономической политики, именно крупных собственников, опережавших действия органов госуправления, наделенных профессиональной политической ответственностью за развитие производства. Создается впечатление, что те, кто непосредственно отвечает за финансовопроизводственную политику, изучив исторический опыт, ждут, когда само производство выдвинет «локомотивы» для продвижения имеющегося состава. Г. Греф, в руководители Сбербанка вышедший из названного сектора правительства, открытым текстом на упомянутом «Гайдаровском форуме» сказал о необходимости активной политики правительства по планированию преодоления кризиса в экономике, вложения финансов в реальное производство, контроля на использование банками госкредитов. Напуганные «неправильным» - не циклическим кризисом, банки не хотят рисковать даже «короткими» кредитами в интересах производства. Они «крышуют» спекулянтов на рынке и сами стали ординарными спекулянтами, пуская в 


\begin{tabular}{|c|c|c|c|c|c|c|}
\hline \multirow{4}{*}{ Impact Factor: } & ISRA (India) & $=3.117$ & SIS (USA) & $=0.912$ & ICV (Poland) & $=6.630$ \\
\hline & ISI (Dubai, UAE & $=0.829$ & РИНЦ (Russia & $=0.156$ & PIF (India) & $=1.940$ \\
\hline & GIF (Australia) & $=0.564$ & ESJI (KZ) & $=8.716$ & IBI (India) & $=4.260$ \\
\hline & JIF & $=1.500$ & SJIF (Morocco & $=5.667$ & OAJI (USA) & $=0.350$ \\
\hline
\end{tabular}

финансовый оборот госкредиты, оставляя производящие предприятия без кредита, либо назначая смертельные для них нормы расчета

Предприятиям легпрома в подобной ситуации несколько проще действовать. Вопервых, замена оборудования не столь затратное дело. Для примера: оснащение элементарным современным оборудованием физической лаборатории обходится в 5 млн. долларов. Вовторых, можно обойтись «короткими» деньгами, что стыкует интересы финансиста и производителя. Но в то же время предприятия легпрома более зависимы от быстро меняющейся конъюнктуры рынка, следовательно, нужно уметь крутиться быстро, уметь использовать центробежные силы - диверсифицировать производство. «Диверсификация»

многопрофильное слово. В словарях выделяют 4 5 значений. В контексте нашего исследования актуальны три: «Диверсификация производства» как распространение хозяйственной деятельности на новые сферы, разветвление производства, расширение ассортимента изделий; вид стратегии маркетинга, предусматривающей расширение видов продукции, производство которой не связано с основным направлением производственной деятельности данного предприятия и кредитная диверсификация распределение капиталовложений.

Диверсификация в настоящее время «работает» в режиме «наибольшего благоприятствования», разумеется, при наличии творческого подхода, взвешенных рисков и умело выстроенного мониторинга. Мы имеем в виду начавшийся переход в развитии массового производства из первого типа во второй - «lean production», что можно перевести как «щадящее» или «рачительное производство».

Данный тип производства принципиально меняет саму цель производственного процесса. При этом традиционная задача изготовления большого числа однотипных изделий, отвечающих требованиям нормативной документации, из которых потребитель должен выбрать наиболее подходящие для него, заменяется задачей изготовления именно такого изделия, какое нужно данному потребителю и именно в требуемом объеме и в определенное время.

Новый тип организации массового производства смещает исследования оптимизации планирования на изучение своеобразия рыночного спроса как суммарного выражения индивидуально различающихся пожеланий. Рынок персонифицируется в зависимости от большого количества задействованных показателей, что требует усиления диверсификации производства. Изменяется характер рынка, и предприниматели обязаны на эту трансформацию адекватно и быстро реагировать.
Для изменения парадигмы, интегрирующей политику организации и управления производством, осуществляющейся его перестройки недостаточно, но серьезная модификация в планировании деятельности предприятий давно необходима. И она началась, может быть пока в сознании производственников и собственников, однако это естественное введение в практику. Изучение мозаики рыночного спроса усложнилось поиском новых рынков сбыта. Стремление захватить рынок в 2016 г. неразумно, равно как и мечта перегнать Китай, нам его и догнать только во сне можно. К счастью перегонять можно по-разному. Самый примитивный вариант - сделать что-то больше, более перспективный - опередить, втиснуться в структуру рынка, где плотность его не столь велика. Гендиректор Новосибирского предприятия «Фабрика одежды» Н. Трещев уверен, что реально втиснуться в ряды продукции «пошитой качественно» из достаточно дорогих тканей, интересного дизайна. В 1990-е годы Россию завалили «ножками Буша», и казалось, ничто не способно вытеснить их с рынка. В нынешнее время их даже не вспоминают. Наш птицепром победил. Почему мы должны бояться интервенции китайского ширпотреба? Нужны протекционистские меры в рамках ВТО, ШОС, но в принципе не в них суть дела. Движение продуктивно своей независимостью от внешних факторов. Устойчивое развитие - следствие самодвижения. Если не способствуют развитию наличные условия, надо искать резервы в самом процессе, «снимая» негативное действие внешних обстоятельств.

Государство обязано внести перелом в падении престижа профессий, связанных с легпромом, создать привлечение для тех, кто решил посвятить себя этому интересному делу. Собственники ищут резервы поднять зарплату. Она по НCO в 2016 г. не превышала 14 тыс. рублей, что составляет половину зарплаты от средней по регионам. Директор группы обувных компаний А. Титов выход видит в переходе производства на автоматизированные комплексы. Компании в прошлом году на приобретение итальянского и тайваньского оборудования затратили 350 млн. рублей, что позволило привлечь квалифицированных специалистов, осуществить переподготовку кадрового костяка и повысить зарплату в среднем до 28 тыс. руб. Прогноз развития производства А. Титов связывает с наращиванием изготовления обуви средне ценового сегмента. В пользу прогноза А. Титова работает и сокращение присутствия на отечественном рынке турецкой продукции.

Надо учитывать и то, что экономический рост Китая неизбежно приведет к повышению 


\begin{tabular}{|c|c|c|c|c|c|c|}
\hline \multirow{4}{*}{ Impact Factor: } & ISRA (India) & $=3.117$ & SIS (USA) & $=0.912$ & ICV (Poland) & $=6.630$ \\
\hline & ISI (Dubai, UAE & $=0.829$ & РИНЦ (Russia & $=0.156$ & PIF (India) & $=1.940$ \\
\hline & GIF (Australia) & $=0.564$ & ESJI (KZ) & $=8.716$ & IBI (India) & $=4.260$ \\
\hline & JIF & $=1.500$ & SJIF (Morocco & $=5.667$ & OAJI (USA) & $=0.350$ \\
\hline
\end{tabular}

расходов на зарплату. Это подчеркнет актуальность логистических расчетов. В итоге китайцы потеряют экономическую привлекательность, и с ними можно будет конкурировать в сегменте, заинтересовавшем А. Титова. У российских промышленников есть и такой козырь, как свое сырье натурального происхождения. Надеемся, что обещанные вложения в сельскохозяйственное производство дойдут до ферм и полей.

Рынок для легпрома прирастает и за счет социокультурного прогресса, в частности, благодаря развитию профессионального спорта, увеличению востребованности тех, кто выбирает спорт как путь к здоровому образу жизни. В конце 2015 года газета «Спортэкспресс» опубликовала интервью с председателем правления Российской Outdoor Группы А. Гребцовым. «Рынок outdoor товаров обслуживает альпинизм, туризм, экстремальный спорт, спецподразделения, спасательные формирования, полярные службы и войска. Это направления, для которых необходима сверхпрочная, морозоустойчивая, водонепроницаемая экипировка, отвечающая самым новым мировым стандартам безопасности и комфорта». А. Гребцов сообщил интересные подробности, в частности, он сравнил технологическую базу производства качественной продукции в РФ, Европе и Азии. Мы «несколько отстали», по его оценке, от азиатского потенциала, но с Европой «Точно можем конкурировать... в России существует около 30 компаний, которые умеют хорошо шить». После введения запрета импорта для госзаказа и гособоронзаказа доля материалов из стран-членов Таможенного союза, поставляемых для силовых ведомств страны, увеличилась с 30 \% в 2011 году до 83 \% в 2016 году. В 2017 году тенденция увеличения доли материалов производства стран КПЭС, используемых для производства вещевого имущества должна составлять порядка 85 - $90 \%$. Разворот госзаказа в сторону отечественного производства откроет возможности для смежников химической промышленности (сырье для нити, фурнитуры, мембраны, утеплителей). Вырастит производство ткани, пошив одежды, что потянет разработку оборудования. А. Гребнев полагает, что для закрепления достигнутых результатов важно:

1. четко дать понять крупным торговым сетям важность приобретения и размещения товаров, произведенных в России, разумеется, с учетом их надлежащего качества;

2. размещать в первую очередь заказы на производство у тех «кто уже встал на ноги и умеет шить». Они доказали свою состоятельность;

3. оказать помощь компаниям с получением европейской сертификации материалов, иначе зарубежные фирмы ими не заинтересуются, а товар, произведенный у нас, не попадет на Запад;

4. активно поддерживать компании коллективными стендами на международных выставках;

5. представлять таким предприятиям субсидии по кредитам на закупку сырья и материалов. Доля этих кредитов в общем объеме кредитования должна составлять от 50 до $85 \%$;

6. освобождать современное импортное оборудование от ввозных пошлин и НДС. Оборудование, применяемое в пошивочных цехах, на 90 \% импортные;

7. внедрять льготный лизинг.

Как видно, программа А. Гребнева систематизирует основные и первостепенные шаги в направлении легпрома к тому, чтобы вернуть себе прежнее значение. Однако Гераклит был прав, говоря, что нельзя войти дважды в одну и ту же реку. Подъем легпрома должен быть осуществлен на новой технологической, экономической и правовой базе.

4. В новое время необходимо обстоятельно работать над культурой покупательского спроса воспитывать покупателя. Мы неоднократно в своих публикациях подчеркивали, что понимание качества естественных явлений и искусственных не тождественно. Потребительский товар произведен человеком и для человека. В нем отчуждается человеческая сущность, в том числе и социокультурный статус личности. Следовательно, и понимание качества должно включать субъективное восприятие свойств товара посредством чувств и рефлексии. Восприятие качества нельзя пускать на «самотек», отдавать чувственной стихии или упрощенному мышлению. Важно научиться не только искусству современного дизайна, качественно шить обувь, одежду, необходимо помочь потребителю во всем этом разобраться, направить его эстетические и гигиенические представления, заставить его сопереживать, испытывать удовлетворение от приобретенного товара.

Мудрый Будда заложил в восьмеричный путь четыре ключевых шага: правильное понимание; принятие правильного решения; нахождение правильных слов и, наконец, правильные действия, направленные на реализацию правильных решений. Судьба легпрома сейчас зависит от того, каким будет этот последний шаг. Его исполнение - функция Правительства. Политическая парадигма предельно проста - нам не следует ни с кем соревноваться в борьбе за мировой рынок, тем более с китайцами. Китайцы по праву хотят обуть и одеть весь мир. В КНР живет пятая часть населения Земли. Наша задача совсем иная. Нам нужно сделать так, чтобы китайцы не обували и не одевали нас. Перевести покупательный спрос на собственное российское 


\begin{tabular}{|c|c|c|c|c|c|c|}
\hline \multirow{4}{*}{ Impact Factor: } & ISRA (India) & $=3.117$ & SIS (USA) & $=0.912$ & ICV (Poland) & $=6.630$ \\
\hline & ISI (Dubai, UAE & $=0.829$ & РИНЦ (Russia) & $=0.156$ & PIF (India) & $=1.940$ \\
\hline & GIF (Australia) & $=0.564$ & ESJI (KZ) & $=8.716$ & IBI (India) & $=4.260$ \\
\hline & JIF & $=1.500$ & SJIF (Morocco & $=5.667$ & OAJI (USA) & $=0.350$ \\
\hline
\end{tabular}

производство, заинтересовать товарами, произведенными в стране. Задача такая нам вполне по силам, как говорят производители. И Правительству нужно делать последовательно и своевременно свою прямую работу, то есть, думать, принимать решение, доводить всё до результата, работать в команде и, главное, уважать друг друга в этой команде.

Но сначала необходимо назвать этой команде сами проблемы, характерные сегодня, но что особенно важно, завтра, для легкой промышленности и приведенные на рис. 3.1.

На рис. 3.1 приведены системные проблемы отрасли, причины их возникновения и результат воздействия проблем на основные показатели деятельности легкой промышленности. Возникновение системных проблем в отрасли обусловлено внутриотраслевыми и внешне отраслевыми причинами. Они связанны как с деятельностью самой отрасли, так и с происходящими институциональными преобразованиями и изменениями в национальной экономике, в сфере законодательной и внешнеэкономической политики страны, а также с изменениями в мировой экономике.

В основном это происходит из-за структурных диспропорций легкой промышленности - несоответствием в настоящий момент масштаба и возможностей отрасли качественно удовлетворить растущий спрос на продукцию, приостановить критическое падение доли отечественных товаров на внутреннем рынке и предотвратить возникшую угрозу потери национальной безопасности страны.

Причинами первой группы проблем технической и технологической отсталости легкой промышленности от зарубежных стран являются:

- невысокий потенциал установленного в отрасли оборудования, большая часть которого морально и физически устарела. Доля оборудования в станочном парке отрасли (по оценке Росстата), эксплуатируемого до 5 лет составила на начало 2017 года всего 1,2 \%, 6 - 10 лет уже 39,6 \%, 11 - 20 лет аж 45,4\% и более 20 лет $-13,8 \%$.

Изношенное и морально устаревшее оборудование неспособно не только производить современный ассортимент качественной продукции, но создает и неудовлетворительные условия труда, приводящие к повышенному производственному травматизму. В результате действия этого фактора удельная трудоемкость производства в отрасли в $3-5$ раз выше, чем за рубежом;

8. отсутствие

технологических автоматизированных производством;

9. меньшие, по сравнению с принятыми в мире стандартами, темпы технологического обновления. Коэффициент обновления оборудования на российских предприятиях составляет $1-2 \%$ в год и осуществляется за счет кредитных и собственных средств, на зарубежных фирмах этот показатель составляет 16 - $19 \%$, что в значительной степени связано с инвестиционной поддержкой со стороны их государств, заинтересованных в развитии легкой промышленности. Низкий уровень обновления оборудования приводит к сокращению производственных мощностей (за счет значительного превышения вывода морального и физически изношенного оборудования над вводом нового).

За последние 5 лет производственные мощности сократились:

- по хлопчатобумажным суровым тканям на 14 процентов;

- по льняным тканям на треть, а по шерстяным тканям почти в 4 раза;

- по трикотажным изделиям в 1,8 раза, чулочно-носочным на 10 процентов;

- $\quad$ по обуви на 62 процента.

Резюме: состояние основных фондов, особенно их активной части, не соответствует современным требованиям по показателям, характеризующим конкурентный и технический уровень производственного потенциала отрасли;

- существенное отставание от зарубежных предприятий в уровне организации производства, в оперативном контроле за технологическим процессом, в эффективности работы маркетинговых служб предприятий и большой в 2 - 2,5 раза продолжительностью выполнения заказов на изготовление продукции. 


\begin{tabular}{|c|c|c|c|c|c|c|}
\hline \multirow{4}{*}{ Impact Factor: } & ISRA (India) & $=3.117$ & SIS (USA) & $=0.912$ & ICV (Poland) & $=6.630$ \\
\hline & ISI (Dubai, UAE & $=\mathbf{0 . 8 2 9}$ & РИНЦ (Russia) & $=0.156$ & PIF (India) & $=1.940$ \\
\hline & GIF (Australia) & $=0.564$ & ESJI (KZ) & $=8.716$ & IBI (India) & $=4.260$ \\
\hline & JIF & $=1.500$ & SJIF (Morocco) & $=5.667$ & OAJI (USA) & $=0.350$ \\
\hline
\end{tabular}

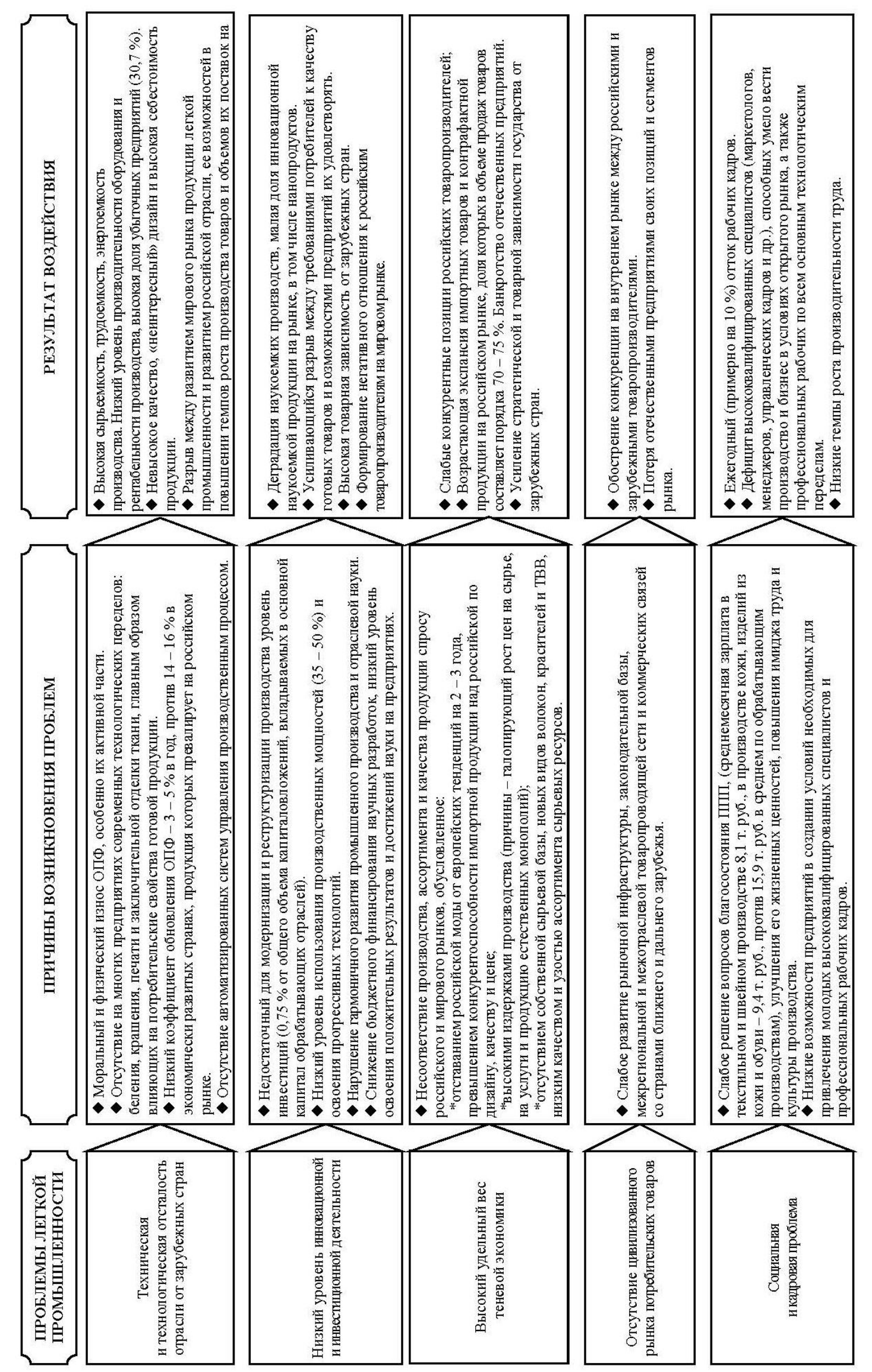

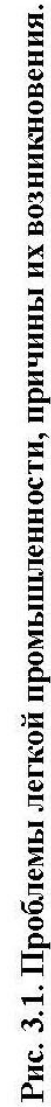




\begin{tabular}{|c|c|c|c|c|c|c|}
\hline \multirow{4}{*}{ Impact Factor: } & ISRA (India) & $=3.117$ & SIS (USA) & $=0.912$ & ICV (Poland) & $=6.630$ \\
\hline & ISI (Dubai, UAE & $=0.829$ & РИНЦ (Russia) & $=0.156$ & PIF (India) & $=1.940$ \\
\hline & GIF (Australia) & $=0.564$ & ESJI (KZ) & $=8.716$ & IBI (India) & $=4.260$ \\
\hline & JIF & $=1.500$ & SJIF (Morocco & $=5.667$ & OAJI (USA) & $=0.350$ \\
\hline
\end{tabular}

В результате воздействия указанных причин возникает высокая зависимость текстильных предприятий от качества сырья, красителей и текстильно-вспомогательных веществ (ТВВ) и, как следствие, высокие издержки производства, обусловленные высокой стоимостью сырья, красителей, ТВВ и фурнитуры (большая доля которых завозятся из-за рубежа), и высокими затратами на энергоносители, цены на которые необоснованно растут сверхбыстрыми темпами; и слабая конкурентоспособность на отечественном и европейском рынках российских товаров в сравнении с импортными, как по качеству, дизайну и цене, так и по ассортименту, что является основным препятствием успешной конкуренции отечественных производителей с зарубежными.

Вторая группа проблем - низкий уровень инновационной и инвестиционной деятельности обусловлена следующими причинами:

- отсутствием инвестиций, необходимых для модернизации отрасли и внедрения «прорывных» инновационных и инвестиционных проектов, позволяющих снять структурные ограничения развития отрасли и выйти на производство совершенно новых (по потребительским свойствам) видов продукции, востребованных на внешнем и внутреннем рынках, при этом важно иметь в виду, что если сегодня отечественная легкая промышленность может покрывать потребности в секторе государственных закупок, то завтра, когда увеличатся спрос на продукцию, собственное производство не сможет удовлетворить растущую потребность даже в этом сегменте - что является недопустимым. В этой связи развитие импортозамещения через рост выпуска качественной продукции - единственно возможный путь решения проблемы производственного потенциала, рост которого, начавшись в государственном секторе, перейдет на рынок в целом;

- сокращением объема и результативности научно-исследовательских разработок по причине снижения объемов бюджетного финансирования НИОКР (в 2016 году за счет средств бюджета выполнено НИОКР на 22,7 млн. руб., в 2017 году - на 25,0 млн. руб.). В наибольшей степени это затронуло фундаментальные и поисковые исследования. Многие научные разработки, способные составить новую технологическую основу отрасли для расширения производства конкурентоспособной наукоемкой продукции, не доведены до завершения и требуют продолжения и углубления разработок. Научным организациям не выделяются и средства на развитие их экспериментальной базы, что снижает эффективность научных разработок. И это, несмотря на то, что достижения российских ученых не уступают и даже многие из них превосходят мировой уровень в области создания новых технологий и нового конкурентоспособного ассортимента продукции. О значимости отраслевой науки говорит тот факт, что за 2014 - 2017 годы шесть научных работ удостоены премии Правительства Российской Федерации в области науки и техники.

Ведущие зарубежные страны на развитие науки и ее экспериментальной базы вкладывают 6 - $9 \%$ средств от оборота продукции, что позволяет им стабильно добиваться высоких достижений в науке, повышать технологический уровень производства и конкурентоспособность товаров в соответствии с требованиями мирового рынка.

Непринятие мер по решению проблем, связанных с развитием науки и эффективностью научного обеспечения отрасли, приведет к неизбежности появления в ее работе возможных рисков экономического и социального характера. Лишенная притока новых технологий отрасль не сможет дальше конкурировать с иностранными фирмами, что скажется на возможности российских товаропроизводителей в сохранении своих позиций на внутреннем рынке и в завоевании новых сегментов на зарубежных рынках. Технологическое отставание отрасли уже в обозримой перспективе может стать необратимым процессом, что повысит стратегическую и экономическую опасность России.

Низкий уровень освоения в промышленности положительных результатов научных разработок и инноваций (менее 1 процента предприятий) - это отрицательно сказывается на технологической модернизации, на расширении ассортимента продукции (как гражданского, так и стратегического назначения) и качестве, возможности придавать ей новые функциональные и потребительские свойства, используя современные технологии, в том числе, нанотехнологии.

Без принятия действенных мер по улучшению сложившейся ситуации в отрасли её состояние может достичь критического уровня. Особенно актуальна задача повышения конкурентоспособности для обувных предприятий, которые в силу внешних факторов (усиление конкуренции вследствие глобализации, мировой финансовый кризис) и внутренних (неэффективный менеджмент) утратили свои конкурентные позиции на внутреннем и внешнем рынках. В ответ на негативные процессы во внешней среде усиливаются процессы регионализации и создания различных сетевых структур, одной из которых является союз товаропроизводителей и государства.

Существуют три основных варианта концепции предприятия в развитой экономике: неоклассическая, агентская (акционерная) и концепция партнерских отношений. 


\begin{tabular}{|c|c|c|c|c|c|c|}
\hline \multirow{4}{*}{ Impact Factor: } & ISRA (India) & $=3.117$ & SIS (USA) & $=0.912$ & ICV (Poland) & $=6.630$ \\
\hline & ISI (Dubai, UAE & $=0.829$ & РИНЦ (Russia) & $=0.156$ & PIF (India) & $=1.940$ \\
\hline & GIF (Australia) & $=0.564$ & ESJI (KZ) & $=8.716$ & IBI (India) & $=4.260$ \\
\hline & JIF & $=1.500$ & SJIF (Morocco & $=5.667$ & OAJI (USA) & $=0.350$ \\
\hline
\end{tabular}

В концепции партнёрских отношений, или теории заинтересованных сторон, рассматривается зависимость действий фирмы от интересов широкого множества заинтересованных сторон, к числу которых относятся потребители, поставщики, акционеры, управляющие, работники и др. При этом каждый из партнёров имеет определенные права на контроль над предприятием, поэтому концепция предполагает необходимость принятия решений с учетом их интересов.

Теория стратегического управления является одним из самых непростых разделов управленческой науки. За достаточно короткий период существования, характеризовавшийся бурным развитием целого ряда концепций, она успела превратиться в самостоятельную научную дисциплину с собственной академической инфраструктурой. Важнейшим вопросом, на который должна дать ответ теория, является определение источников долгосрочной конкурентоспособности предприятий. Эти источники определяются стратегией предприятия и, соответственно, поднимают вопрос о еe природе.

Надежность и универсальность - признаки качества знаний. Надежность позволяет свести к минимуму риски, универсальность снимает напряжение с поиска новых решений проблемы «от добра добра не ищут». За качество приходится платить. Плата, как принято считать, имеет финансовую зависимость, однако это не всегда выглядит непосредственно. В истории цивилизации есть два выдающихся достижения на уровне революций, явно не получивших эквивалентной оценки, а именно:

- открытие цены знаниям, сопоставимой с ценой для человека вещей, «знание - сила»;

- осознание особого значения теоретических знаний в форме понятий и смежных с ними форм абстрактного мышления - суждений, умозаключений. Это закономерно привело к необходимости разрабатывать специфическую технологию их производства - методологию познания сущности отношений существующих явлений. Видимая часть мира «рассчитана» на потребителя, невидимая - на производителя. Конкуренцию производителей можно формализовать в виде простой технической задачи - проникнуть через хаотическое множество явлений видимой части мира в его скрытую часть, разобраться в ней, чтобы, вернувшись, понять хаос как порядок сосуществования и развития явлений. Упорядоченность и есть закономерность. Законы только в учебниках существуют сами по себе, отдельно. В действительности закон - это устойчивость, общность и необходимость порядка того, с чем мы имеем взаимодействие - познаем, воспроизводим, изменяем, управляем.
Экономическая наука в XX веке попала в сложное положение, которое к концу столетия сделалось критическим. Теория А. Смита и метод К. Маркса не вписались в контуры идеологии развитого капитализма. В Европе и Северной Америке сама мысль об историчности капитализма воспринималась как ересь. История капитализма имеет начало, но наличие начала не может быть основанием вывода о конечности. Математика - наука точная, она допускает бесконечность в одну сторону. Диалектическое толкование бесконечности - метафизическое, отвлеченное от реальной истории. Спасение экономической науки надо искать не в историческом, а формально-логическом понимании действительности, то есть в математических исчислениях, статистике.

Мы остановим погружение в философские, правильнее сказать, в методологические основания науки, но не потому, что надо быстрее окунуться в практическое дело, а вследствие значимости для успешного осознания производства товара понимания того, что всякое производство предполагает воспроизводство, наряду с товаром, отношений. Производство начинается с достижения определенных отношений и приводит к развитию этих отношений - между производителями, производителями и потребителями. Разобраться в столь сложно выстроенном производстве можно лишь с привлечением научного анализа на основе понятийного мышления.

Далее цитируем: «Для пошива школьной одежды должны использоваться ткани из натуральных волокон, таких как шерсть, лен, хлопок. Эти ткани наиболее гигиеничны, обладают высокой гигроскопичностью и хорошими терморегулирующими свойствами». По итогам исследования, из 98 производителей школьных брюк продукция только 14(!) соответствовала знаку качества, являлась безопасной для здоровья согласно требованиям. Из 30 производителей сорочек 28 имели нарушения».

Вряд ли кто, из посвященных в состояние отечественного легпрома, ожидал иных результатов. Поражает не столько удручающая статистика, сколько комментарии специалиста, адресованные потребителю продукции швейного производства. Специалист через журналиста советует: «Если на ярлыке не указана информация о производителе - его наименовании и местонахождении, составе ткани, дате выпуска это повод задуматься».

Переход к самостоятельному нормированию технических характеристик реально возможен в границах объективных параметров качества исключительно при наличии двух условий: 


\begin{tabular}{|c|c|c|c|c|c|c|}
\hline \multirow{4}{*}{ Impact Factor: } & ISRA (India) & $=3.117$ & SIS (USA) & $=0.912$ & ICV (Poland) & $=6.630$ \\
\hline & ISI (Dubai, UAE & $=0.829$ & РИНЦ (Russia & $=0.156$ & PIF (India) & $=1.940$ \\
\hline & GIF (Australia) & $=0.564$ & ESJI (KZ) & $=8.716$ & IBI (India) & $=4.260$ \\
\hline & JIF & $=1.500$ & SJIF (Morocco & $=5.667$ & OAJI (USA) & $=0.350$ \\
\hline
\end{tabular}

- освоения современных технологий производства продукции;

- сложившейся высокой профессиональной культуры, системообразующим фактором которой является личная форма ответственности.

Разумеется, к базовым условиям надо добавить негосударственный контроль за производством, своего рода народный контроль. ОНФ может быть центром подобного народного надзора, но есть опасность его партийного оформления. Действительная сила ОНФ как раз и заключена в статусе независимой от межпартийных отношений организации, непосредственно подчиненной Президенту. Высший управленческий менеджмент, к сожалению, приобрел опыт приручения тех, кто проявляет самостоятельность.

В СССР в 50 - 80-е годы сформировалась система управления качеством, мало в чем уступавшая зарубежному опыту. Эта система постоянно совершенствовалась с учетом полученного позитивного и негативного опыта вплоть до конца 1980-х годов. Все стало рушиться в волнах, рожденных «новым политическим мышлением». Окончательно системную политику в отношении организации управления качеством захлестнуло демократическое цунами девяностых. Кризис и «шоковая терапия» сняли актуальность проблемы на последующие десятилетия. Причины деактуализации интереса к качеству лежат на виду, а именно:

- достижения политики управления качеством советского периода были связаны с особенностями социалистического типа планирования, построенного на принципе директивности, в котором, в отличии от индикативного планирования, экономическое стимулирование было подчинено политическим целям непосредственным образом. Когда стала ненужной административно-командная практика управления предприятиями, вместе с ней ушла в историю и практика управления качеством;

- не секрет, что с развалом СССР на будущее России смотрели совсем по-другому «системно». Российскую экономику пытались не встроить в мировое производство, а пристроить в интересах сложившейся архитектуры. Нам отвели место производителей и поставщиков сырья, в основном естественного происхождения. Качество такой продукции обусловлено не производством. Качество же производства зависит от размера добавленной стоимости - чем меньше затрат, тем больше разница между ценой и себестоимостью, выше прибыль. Добыча барреля нефти в Катаре и Саудовской Аравии обходится существенно меньше, чем в РФ. Отказавшись от контроля за рынком, государство последовательно освободило себя и от обязанности контролировать процесс производства. И это произошло притом, что бюрократический аппарат и расходы на его содержание увеличились на порядок. Само понятие «управление качеством» понизили до уровня «контроль за качеством», после чего каждый производитель мог сам управлять качеством. В конце концов, качество упростили до технического регулирования;

- качество производства и продукта производства функционально связаны с качеством рынка, качество же рынка, в свою очередь, зависит от покупательской готовности приобретать продукты, отмеченные знаком качества. Качественный товар бывает востребованным при двух обязательных условиях: платежеспособному спросу массового покупателя и добросовестностью продавца. Ни того, ни другого на отечественном рынке нет. Даже в бутиках и элитных магазинах покупатель не чувствует себя гарантированно защищенным от контрафактной продукции и обманщика производителя.

Рынок - неотьемлемая часть общества. Порядок на рынке отражает состояние общества, а производитель ориентируется на состояние рынка. Для него барометром служит не национальный интерес - возможности рынка. Рынок - движущая сила производства. Если бы культура рынка действительно опережала культуру производства, то возражения против потребительского подхода к производству сократились бы до минимума. На самом деле культуру рынка в России заложили не производители и тем более не потребители с их тощим кошельком. На нашем рынке с самого начала властвуют посредники и спекулянты. Под них выстроено и законодательство, допускающее массу различных толкований действий и такое же количество возможностей избежать уголовной ответственности. Управление качеством в подобной ситуации превратилось в манипулирование качеством в интересах хозяев рынка. Пока мы не перестроим отношения в сфере обмена товара на деньги и не поднимем покупательский платежеспособный спрос до возможности выбора качественного продукта, у нас проблема качества останется на уровне экономической теории.

Производитель в настоящее время не заинтересован изготовлять качественный продукт, затраты высокие, себестоимость изделий вырастит, реальную цену существенно увеличат посредник и продавец. В итоге рынок такого продукта «не переварит» и производитель будет поражен смертельной болезнью № 1 по Э. Демингу. В ограниченном - явно мизерном для России масштабе качественные вещи гарантированно делают, изготавливают, только никакого отношения к ситуации в производстве 


\begin{tabular}{|c|c|c|c|c|c|c|}
\hline \multirow{4}{*}{ Impact Factor: } & ISRA (India) & $=3.117$ & SIS (USA) & $=0.912$ & ICV (Poland) & $=6.630$ \\
\hline & ISI (Dubai, UAE & $=0.829$ & РИНЦ (Russia & $=0.156$ & PIF (India) & $=1.940$ \\
\hline & GIF (Australia) & $=0.564$ & ESJI (KZ) & $=8.716$ & IBI (India) & $=4.260$ \\
\hline & JIF & $=1.500$ & SJIF (Morocco & $=5.667$ & OAJI (USA) & $=0.350$ \\
\hline
\end{tabular}

приведенная практика не имеет, она эксклюзивная.

Попытки исполнительной власти в нулевые годы активировать интерес к TQM успех имели опять-таки локальный и временный. В советское время команды сверху выглядели логичными и заставляли с ними считаться. Изменившаяся с социалистической на капиталистическую реальность на эти инициативы прореагировала вяло, без всякого энтузиазма, можно сказать чисто просветительски, но не практически. Не удивительно, что к отклеившимся подошвам обуви добавились неисправные ракеты, не способные подняться в космос.

К вышеприведенным причинным факторам добавим застарелую болезнь, доставшуюся российскому менеджменту в наследство от социалистического периода. «Создание системы качества в России натыкается еще на одну проблемы, типичную для нашей страны, пишут Б.С. Алешин с соавторами. Она состоит в том, что инструкции пишутся для кого-то, а не для конкретного работника. Поэтому общепринятой ситуацией стало простое нарушение инструкций. Это принципиально недопустимо на предприятиях, использующих систему управления качеством». Не доверяя высшему менеджменту решение этой проблемы, Б.С. Алешин ищет поддержку на корпоративном уровне - «... при подготовке и создании системы качества в России полезно расширить сферу действия проблемы и рассмотреть вопрос о создании системы корпоративных стандартов, поддерживающей систему качества».

Б.С. Алешин - известный специалист в области управления, занимал самые высокие посты в российском правительстве и дело знает изнутри. Ему должна быть знакомой история с проблемой подготовки менеджеров, корнями уходящая в советские времена. Ее пытался решать А.Г. Аганбегян в бытность директором Института в системе СОАН СССР. Делал он это весьма серьезно, инициировав создание Совета директоров крупнейших предприятий Сибири. Внешне вопрос выглядел просто: экономиступравленец (тогда заморское «менеджер» не использовалось) являет собой «свободного художника», или его профессиональную подготовку необходимо выстроить как надстройку над производственноориентированном фундаменте, т.е. сначала профориентированное обучение, только потом экономическое образование. Формальное решение проблемы имелось в ведомственных вузах, где уже в названии выпускающих кафедр связывались экономическая и производственная составляющие, например, в вузах МПС кафедра называлась «Экономика на транспорте».
Дискуссия у А.Г. Аганбегяна закончилась ожидаемо - большинство посчитало целесообразным экономическую подготовку связать с производственной спецификой. Только так ей можно придать необходимый уровень конкретности. Реформы 1990-х годов разработанную схему отменили, привели подготовку менеджеров у нас в соответствие с порядком, установленным у них, чью экономику определила в качестве эталона. Алогичность экономической политики не скрывали, напротив, превозносили. Абсолютизация в науке не допустима, как тормоз научного творчества. Тем не менее, признавая необходимость переходного этапа, пришедшие во власть экономисты в учителя взяли тех, кто по учебникам истории знал о том, что надо делать во время перехода. Хотели на счет «раз-два» оказаться в постиндустриальной экономике, миную развитую индустриальную. При всех дефектах социалистической индустриализации, она стала объективным историческим фактом за две пятилетки, а за пять «пятилеток» даже реиндустриализацию не сумели осуществить. В итоге вернулись к прежней логике развития. Локомотивами индустриального прогресса сделали ВПК и Роскосмос, надеясь, что они потянут за собой развитие остальной промышленности. Но, не будучи уверенными в способности остальных справиться с новыми задачами, ибо и старые они не выполняют, власть призвала ВПК развернуть производство ассортимента массового народного потребления в целях удовлетворения бытовых потребностей населения.

Одним из основных правил управления качеством специалисты считают возвращение в исходные позиции, если процесс не пошел. Поэтому реставрацию прошлой модели экономического подъема надо записать в актив власти. К этому бы еще приложить и принцип последовательности в реализации социалистического императива о единстве теории и практики. Советские випперсоны из Политбюро решения не разрабатывали. Они их согласовывали и принимали. Проекты решений готовились профессионалами, консультантами, «субподрядчиками» и «инициаторами», у них были ученые АН СССР и наиболее успешные руководители производства. Случайный человек в промышленные отделы обкомов партии, ЦК КПСС попасть мог, только оказавшись Штирлицем. Был налажен партийный и народный контроль. Естественно не совершенный, но действенный. Разложение стартовало тогда, когда с приходом М. Горбачева его ставленники объявили себя и учеными, и опытными производственниками, и пророками, утратив критическую способность. Диалектика в управлении уступила место стремлению найти 


\begin{tabular}{|c|c|c|c|c|c|c|}
\hline \multirow{4}{*}{ Impact Factor: } & ISRA (India) & $=3.117$ & SIS (USA) & $=0.912$ & ICV (Poland) & $=6.630$ \\
\hline & ISI (Dubai, UAE & $=0.829$ & РИНЦ (Russia & $=0.156$ & PIF (India) & $=1.940$ \\
\hline & GIF (Australia) & $=0.564$ & ESJI (KZ) & $=8.716$ & IBI (India) & $=4.260$ \\
\hline & JIF & $=1.500$ & SJIF (Morocco & $=5.667$ & OAJI (USA) & $=0.350$ \\
\hline
\end{tabular}

существующий пример, что породило перерождение диалектического мышления, выстроенного на базе исторической конкретности истинного знания, в примитивный эклектизм Е. Гайдара и $\mathrm{K}^{\circ}$.

На закономерном стремлении А. Аганбегяна с сотоварищами объединить научное познание экономики со здравым смыслом и практически выверенным опытом, смыла либеральная абстрактная фантазия.

Критерием уровня предметноориентированных знаний служит качество управления соответствующей областью предметной реальности.

Парадокс экономического управления заложен в специфике движения общественного производства. Чтобы управлять со знанием дела, нужны теоретические, следовательно, общие научные знания, продуцируемые экономической наукой, но управлять практически всегда приходится отдельно взятым предприятием, замыкающим экономическую цепочку. В этом смысле экономическое управление выступает уже как искусство, оно сродни медицине, принцип которой также внешне прост: определяем болезнь, но лечим больного, поэтому алгоритмы хороши в процессе теоретического обучения врача, однако они ограниченно применимы в лечении больного. Нечто близкое у экономического управления и с модой. Высокая мода определяет стиль, цветовое предпочтение, специфику формы изделия, характер его сочетания с отделкой и фурнитурой, тип материала. Что же касается отдельно взятого изделия, то его конкретность утверждается заказчиком, исходя из конституции и финансовых возможностей. Обычно считают, что мода закрепощает, не согласны. Мода предоставляет как раз достаточно свободы действий в заданных параметрах. Она испытывает культурное развитие личности потребителя. Есть свобода и у управляющего предприятием, в том числе и при определении отношения к качеству продукции. Мечта управляющего получить качество за счет сокращения издержек, мечта понятная, ибо в противном случае придется поднимать цену реализации, что неправильно с точки зрения теории управления качеством. Авторитетный японский специалист по менеджменту И. Исикава неоднократно говорил, что безнравственно говорить о повышении цены при повышении качества продукции, так как повышение качества связано со стабилизацией производства, уменьшением дефективности, издержек, а следовательно, с уменьшением себестоимости и цены. По мнению И. Исикавы, о росте цены оправдано судить только в том случае, когда потребитель получает изделие нового технического уровня.
В условиях плохой организации переходного периода к современной высокотехнологической экономике, отягченного рецессией в мировом масштабе и западной политикой санкций в отношении России, вряд ли реалистично рассчитывать на профессиональную ответственность конкретного производителя за качественность производимой продукции. Нравственность родилась раньше товарного производства, однако затем экономическое развитие поставило нравственность под свой контроль, закрепив новое соотношение идеологически. Нравственное развитие только в романах контролируется внутренними силами персонажей. В экономике нравственность существует подобно драгоценному камню в тисках зажима перстня. Почему в стандартах ИСО сделан упор на три точки приложения сил ответственность руководителя, снижение издержек и кадровую политику? Есть три «золотые истины» качественной политики в управлении качеством:

- невежество - первопричина всех бед в управлении, в экономике прежде всего;

- качество - источник доходов, так как сопряжено с сокращением производственных потерь, кроме того оно гарантирует экономическую стабильность, способствует повышению имиджа;

- бережная политика в отношении профессионально подготовленных кадров, такие люди - главное богатство любого производства.

Правила действуют, когда нет никакого резона их не соблюдать - себе дороже каждое нарушение. У нас, в условия селективного контроля за правилами, редкие производители следуют правилам, значительно больше действуют по понятиям, то есть под прикрытием несовершенства правил и договоренности с чиновниками. И здесь мы можем сформулировать суть политического момента, как руководители любили говорить еще не очень давно. Итак, что мы имеем?

Первое, совсем неслучайно экономическую теорию отцепили от политики, политическую экономию нейтрализовали в экономической науке. Богу - богово, кесарю - кесарево. Очень уж Гайдару и олигархам понравился американский экономический либерализм, причем отразили они его специфически. Свободу предпринимательства приняли «на ура», а об американских драконовских мерах за нарушение правил экономической деятельности забыли народу рассказать. Не выгодно было. Вспоминать стали лишь после того, как все поделили, и встал вопрос о перераспределении продуктов приватизации.

В стремлении очистить экономическую теорию от политической нагрузки была скрыта практическая, управленческая составляющая. 


\begin{tabular}{|c|c|c|c|c|c|c|}
\hline \multirow{4}{*}{ Impact Factor: } & ISRA (India) & $=3.117$ & SIS (USA) & $=0.912$ & ICV (Poland) & $=6.630$ \\
\hline & ISI (Dubai, UAE & $=0.829$ & РИНЦ (Russia & $=0.156$ & PIF (India) & $=1.940$ \\
\hline & GIF (Australia) & $=0.564$ & ESJI (KZ) & $=8.716$ & IBI (India) & $=4.260$ \\
\hline & JIF & $=1.500$ & SJIF (Morocco & $=5.667$ & OAJI (USA) & $=0.350$ \\
\hline
\end{tabular}

Экономическое управление отделили от предметной специфики производства, чтобы было как в теоретической механике, физике, химии. Следующим шагом за упразднением политической экономии и приоритета в управлении производством его предметной направленности стало вознесение экономического управления в качестве универсального фактора.

Экономические управляющие сделались законодателями порядка в развитии производства. В Россию в 1990-е понаехало немало экономических советников и консультантов, активизировался едва ли не главный финансовый спекулянт Сорос. Спрашивается, зачем все это нужно было и кому выгодно? Ответ не столь сложен - эти перемены обеспечивали прикрытие перехода от политики управления качеством производства к политике манипулирования качеством. Параметры качества стали определять экономические управляющие, естественно, исходя из управленческих интересов. К. Маркс показательно назвал попытку экономиста Прудона разобраться в философских основах нищеты «нищетой философии». Либеральные экономисты наступили на те же «экономические» грабли, что и их французский предшественник. Результат оказался тем же. Убрав предметную определенность, экономисты - управляющие реставрировали схоластическую философию «реалистов». Вместо движения к конкретности истинного знания они абсолютизировали абстракцию общих идей. Экономическая наука призвана реконструировать объективную, предметно определенную реальность, а не быть производителем удобных для расчета знаний. Так функции науки и философии трактовали в Средние века теологи. Впрочем, по-видимому, именно в подобном статусе науки есть особая заинтересованность, иначе как объяснить уход от объективизации критериев научных оценок.

«Качество» - философская категория, которая вместе с «количеством» образует диалектическую пару, то есть они взаимозависимы. В одной из своих публикаций мы выделили три фундаментальных признака «качества»:

- «качество» является системой определяющих свойств явления;

- в определении «качества» всегда имплицировано количество в одном из своих проявлений - цельность, интенсивность;

- отражая предметное многообразие мира, качество воспроизводит в себе объективность различия явлений, оно структурировано.

«Управление качеством» - понятие политической экономии, оно допускает вариабельность разработки, но в пределах объективности характеристик качества. Манипуляция качеством представляет собой свободное от действительных характеристик определение признаков качества в общем, теоретическом и частном, - практическом масштабов. В экономической теории до 1950-х годов не существовало специфической процедуры для оценки затрат на качество. Господствовал «традиционный подход к определению «оптимальной» стоимости качества». $100 \%$-е соответствие продукта ТУ считалось недостижимым, поэтому цену качества заложили в после покупную перспективу. Полагали, что расходы потребителя на эксплуатацию товара обратно пропорциональны качеству товара. Они уменьшаются по мере качественности товара, стремясь к нулю. Появилось понятие «оптимального уровня качества». Оно соответствовало минимуму стоимости качества для поставщика и потребителя. Общие затраты определялись как сумма затрат производителя и потребителя.

Новая экономическая реальность сложилась в 1970-е годы под непосредственным влиянием научно-технической революции. Возросла техническая сложность продукта, увеличился гарантийный срок. Произошедшие изменения заставили отказаться от упрощенной модели определения затрат на качество. Родилась концепция стоимости качества, опирающаяся на уменьшение за счет более рационального финансирования затрат на качество и снижения общих затрат на производство продукта. Экономику пытались сделать экономной. Акцентирование в управлении качеством сместилось в сторону решения общих задач развития производства, его стандартизации. Г. Тагути вообще назвал мерой качества его стоимость и привел следующие расчеты: одна стирка рубашки обходится в 250 йен, обычно за время службы рубашку стирают 80 раз. Расходы на прачечную составляют 20000 йен. Если смогут пошить рубашку, мнущуюся и загрязняющуюся в два раза медленнее, то экономия потребителя достигает 10000 йен. Предположим, новая рубашка производителю обойдется на 1000 йен больше, а реализация увеличится на 2000 йен, то производитель получит в доход 1000 йен, потребитель выгадает 8000 йен. Общество же будет иметь экономию в 9000 йен плюс сокращение расходов экологической направленности, так как меньше будет отходов от стирки.

Мы не против манипулирования качеством. В определенных границах эта вынужденная мера, свидетельствующая об ограниченности познавательных и иных возможностей. Теория не должна быть консервативной, но манипулирование качеством - тактический уровень управления в отличие от стратегической ценности и значимости управления качеством. 


\begin{tabular}{|c|c|c|c|c|c|c|}
\hline \multirow{4}{*}{ Impact Factor: } & ISRA (India) & $=3.117$ & SIS (USA) & $=0.912$ & ICV (Poland) & $=6.630$ \\
\hline & ISI (Dubai, UAE & $=0.829$ & РИНЦ (Russia & $=0.156$ & PIF (India) & $=1.940$ \\
\hline & GIF (Australia) & $=0.564$ & ESJI (KZ) & $=8.716$ & IBI (India) & $=4.260$ \\
\hline & JIF & $=1.500$ & SJIF (Morocco & $=5.667$ & OAJI (USA) & $=0.350$ \\
\hline
\end{tabular}

Манипулирование - один из инструментов управления, и оно обязано оставаться частным, изменяющимся делом в системе управления качеством.

Второе, что нужно иметь в виду, анализируя перспективу частного самоконтроля качества. Частная инициатива обусловлена общей политической и экономической ситуацией. Социализм можно было построить в отдельно взятой стране, обеспечить конкурентную способность социализма оказалась в данное историческое время невозможным. Капитализм еще силен. Такая же ситуация ждет и частных производителей. Качественный товар он выпустит. Сможет ли работать устойчиво в среде, которая не созрела для подобной практики.

Качественный товар мало уметь производить. Он должен быть востребован массовым покупателем, а такой расклад - уже социально-экономическая политика. Качественную продукцию хотят иметь все и всегда. Только - это абстрактное желание. Оно существует как мечта, сказка. Лишь по мере обретения абстрактными пожеланиями статуса конкретности реальных возможностей сложатся благоприятные условия для приоритетности «хорошего вкуса», и покупатель будет искать качественный товар, а не глядеть с завистью в корзину богатого, но явного меньшинства. В отношениях производителя с покупателем к тому же есть свои поля Хиггса. В природе, проходя через них, частицы наделяются массой и превращаются из частиц энергетических в частицы «вещественные». На рынке товаров, изделие проходит через поля продавцов различного ранга и обретает нереальную цену, которую рекламируют как настоящую, соответствующую качеству. Пока отечественный рынок не будет приведен к нормальному рыночному состоянию, что придется ждать очень долго, заинтересованности в производстве качественного товара не будет. Вполне допустимо полагать, что среди российских производителей немало честных предпринимателей, имеющих искреннее желание накормить, одеть и обуть сограждан как можно лучше. Только кто им это позволит сделать. Рынок их отторгает в качестве «нарушителей конвенции». Законодатели примут законы в согласии с порядком и ценой лоббирования - оно существует легально; чиновники внесут свои комментарии посредством рекомендаций, указаний и т.п.

Разумеется, на нашем рынке имеется некоторая ниша, ею пользуется наиболее респектабельная часть среднего класса. Ниша незначительная по причине тощего социального слоя и его неустойчивости в условиях волатильности развития экономики. Тем не менее, данный сектор есть, и под его запросы производители качественной продукции, к примеру, колбасы по 1500 рублей за килограмм, обуви за 5 тысяч и более, костюмов от 15 тысяч, также существуют. Но какое отношение этот рыночный эксклюзив имеет к характеристике нашей экономики в целом? Разве, служит тем самым исключением из правил, что только их подтверждают. Проблема статуса производителя качественного товара - национального масштаба и потенциал отдельных, относительно благополучных страто, к ней относится как судьба пассажиров, спасающихся в лодке, после того, что сделал шторм с их большим кораблем.

Про наш рынок мы сказали не все, однако главное выделили. У нас власть на рынке у посредников и спекулянтов, часто предстающих в одном лице. Именно с ними связаны коррупционеры-чиновники. Поэтому пропорции, показанные в правой стороне схемы, на нашем рынке выглядят иначе. Особенно в части затрат на проданную продукцию. Эта часть - клондайк для всех кормящихся на рынке, и головная боль для настоящих тружеников. Просто так от своих преимуществ еще никто не отказывался. Без урегулирования рынка никакие благие намерения не найдут качественную дорогу к покупателю, ибо известно куда ведет такая дорога.

Основными причинами отсутствия цивилизованного рынка потребительских товаров являются:

- слабое развитие рыночной инфраструктуры, межрегиональной и межотраслевой товаропроводящей сети и коммерческих связей со странами ближнего и дальнего зарубежья;

- несовершенство законодательства в области производства, экспорта и импорта российской продукции. Учитывая комплексный и многоплановый характер проблем данной группы, необходимы кардинальные меры для их решения, включая государственную поддержку, как это делается в зарубежных странах. Так, например, признание правительствами Китая, Турции и некоторых других стран легкой промышленности стратегической отраслью позволило им довольно быстро превратить устаревшие производства в современные и способствовать мощному развитию в этих странах сырьевого, химического и машиностроительного комплексов.

В России в последние годы со стороны государства предпринимаются некоторые шаги по нормализации ситуации в легкой промышленности. Правительство Российской Федерации предоставило ряд преференций предприятиям отрасли. Уже третий год в страну ввозится технологическое оборудование при нулевых импортных пошлинах и без НДС. Действует механизм субсидирования процентных ставок по кредитам на закупку сырья и 


\begin{tabular}{|c|c|c|c|c|c|c|}
\hline \multirow{4}{*}{ Impact Factor: } & ISRA (India) & $=3.117$ & SIS (USA) & $=0.912$ & ICV (Poland) & $=6.630$ \\
\hline & ISI (Dubai, UAE & $=0.829$ & РИНЦ (Russia & $=0.156$ & PIF (India) & $=1.940$ \\
\hline & GIF (Australia) & $=0.564$ & ESJI (KZ) & $=8.716$ & IBI (India) & $=4.260$ \\
\hline & JIF & $=1.500$ & SJIF (Morocco & $=5.667$ & OAJI (USA) & $=0.350$ \\
\hline
\end{tabular}

материалов. С 2014 года этот механизм распространен на кредиты, получаемые на техническое перевооружение. Оказывается поддержка и стимулирование экспортеров промышленной продукции путем возмещения из федерального бюджета части затрат на уплату процентов по кредитам, получаемым на производство экспортной продукции. Хотя и не большие, выделяются средства из федерального бюджета на проведение НИОКР в интересах легкой промышленности. Общая сумма выделенных средств из бюджета на развитие отрасли за период 2014 - 2016 годы составила 561,64 млн. рублей.

Эффективность преференций: каждый рубль, вложенный в отрасль в виде субсидий по кредитам, обеспечивает дополнительные поступления в бюджеты всех уровней и государственные внебюджетные фонды от 6 до 7 руб., а по отдельным предприятиям - от 20 до 30 руб.

Проведены оперативно-профилактические мероприятия «Контрафакт» по пресечению незаконного оборота товаров легкой промышленности. В частности, в 2016 году в результате было выявлено более 700 преступлений, по которым материальный ущерб по возбужденным уголовным делам составил более 2,7 млрд. руб. В ходе расследования уголовных дел наложен арест на имущество стоимостью более 73 млн. руб., изъято имущества, денег, ценностей и добровольно погашен причиненный ущерб в сумме более 57,6 млн. руб.

Для снижения контрафактной продукции правительство РФ предусмотрело введение с 1 января 2017 года идентификацию меховых изделий или так называемое чепирование (приложение 1 - 4), для того чтобы защитить потребителя от недоброкачествнной и не соответствующей ценности меха изделий с 1 июня 2018 года, такая же акция будет введена для обуви. В перспективе разрабатывается нормативная основа и для швейных изделий, руководители правительства вместе с производителями надеются, что введенные меры существенно снизят контрофактную продукцию и позволят потребителям покупать высококачественную продукцию.

Процесс маркировки всей ввозимой и производимой на территории РФ обуви, запущенный по аналогии с маркировкой меховых изделий, вызывает у большинства обувщиков реакцию если не отторжения, то как минимум опасения. Посвященный новому закону о маркировке конференц-брифинг представителей экспертной группы при минпромторге РФ, прошедший 6 сентября 2017 года в рамках деловой программы выставки «мосшуз», собрал столько слушателей, что зал не смог вместить всех желающих. Конечно, все участники подготовки проекта - и национальный обувной союз, и департамент развития внутренней торговли, легкой промышленности и легализации оборота продукции минпромторга РФ, и даже наиболее крупные игроки рынка постарались развеять опасения рынка (приложение 4).

С использованием созданной системы маркировки можно увидеть структуру отрасли в режиме онлайн, а также отследить случаи занижения таможенной стоимости, схемы ухода от налогообложения и нарушения порядка оборота товаров. На примере меховой отрасли, где маркировка введена в 2016 году: зарегистрировано более 9000 участников (2500 субъектов предпринимательской деятельности); розничные продажи выросли более чем на 51,7 млрд руб. (908 тыс. шт); легальный ввод (производство/импорт) меховых изделий в оборот вырос на 57\% (количество товаров в легальном обороте выросло в 5 раз); промаркировано 3,9 млн изделий (прогноз - 2,5 млн изделий); более $20 \%$ участников проекта легализовали свой бизнес.

Изменить сложившуюся ситуацию и реанимировать легкую промышленность можно, и это подтвердили эксперты - респонденты, проявив единодушие, по основным критериям оценки конкурентоспособности предприятий легкой промышленности, перечень которых, утвержденный по итогам совещания, приведены ниже:

1. Правительству Российской Федерации:

a) предусмотреть при формировании проекта федерального бюджета на 2018 год и на плановый период 2019 и 2020 годов предоставление государственной поддержки предприятиям лёгкой промышленности ежегодно в объёмах не ниже уровня 2017 года. 2018 г.;

Доклад - до 15 октября 2017 г. и до 15 января

б) предусмотреть в рамках Государственной программы развития сельского хозяйства и регулирования рынков сельскохозяйственной продукции, сырья и продовольствия на 2013 2020 годы формирование подпрограммы, направленной на обеспечение лёгкой промышленности качественным сельскохозяйственным сырьём, а также реализацию противоэпизоотических мероприятий в целях ликвидации гиподерматоза крупного рогатого скота.

Срок - 1 февраля 2018 г;

в) рассмотреть вопрос об установлении на федеральном уровне льгот по налогу на имущество организаций в отношении движимого имущества в целях стимулирования модернизации производства и обеспечить внесение соответствующих изменений в законодательство Российской Федерации; 


\begin{tabular}{|c|c|c|c|c|c|c|}
\hline \multirow{4}{*}{ Impact Factor: } & ISRA (India) & $=3.117$ & SIS (USA) & $=0.912$ & ICV (Poland) & $=6.630$ \\
\hline & ISI (Dubai, UAE & $=0.829$ & РИНЦ (Russia) & $=0.156$ & PIF (India) & $=1.940$ \\
\hline & GIF (Australia) & $=0.564$ & ESJI (KZ) & $=8.716$ & IBI (India) & $=4.260$ \\
\hline & JIF & $=1.500$ & SJIF (Morocco & $=5.667$ & OAJI (USA) & $=0.350$ \\
\hline
\end{tabular}

г) принять меры по смягчению в рамках двусторонних международных соглашений с центральными ветеринарными органами зарубежных стран ветеринарных требований, предъявляемых к кожевенному сырью, ввозимому на территорию Российской Федерации;

д) определить реализацию тонкой и полутонкой шерсти, длинного льняного волокна перерабатывающим предприятиям, расположенным на территории Российской Федерации, в качестве обязательного условия предоставления государственной поддержки сельскохозяйственным товаропроизводителям, осуществляющим производство данной продукции, и обеспечить внесение соответствующих изменений в нормативные правовые акты;

е) предусмотреть внесение в законодательство Российской Федерации изменений, направленных на развитие системы обеспечения прослеживаемости оборота товаров легкой промышленности;

ж) рассмотреть вопрос о целесообразности введения утилизационного сбора в отношении обуви;

3) совместно с акционерным обществом «Российский экспортный центр» представить предложения по содействию развитию экспорта российской продукции легкой промышленности, в том числе путём компенсации затрат, связанных с выходом названной продукции на внешние рынки. Радует, что предполагается их реализация в полном объёме и установленные сроки, понимая ответственность названных лиц и наличие у них мотивации действий.

Во многих субъектах Российской Федерации действует и более широкий перечень льгот, в том числе по налогам на имущество, на землю и другие. Вместе с тем существующие преференции и решаемые в той или иной степени проблемы отрасли на федеральном и региональном уровнях пока недостаточны для того, чтобы устранить влияние негативных факторов на развитие отрасли и превратить ее в конкурентоспособный и саморазвивающийся сектор экономики страны, а отечественным производителям укрепить свои позиции на внутреннем рынке и на равных конкурировать на мировом рынке не только со странами ЕС и США, но и с производителями Китая, Турции, Индии и ряда других стран. Отсюда ключевая задача - ускоренная качественная модернизация отрасли и поддерживающих еe инфраструктур с использованием кластерных подходов, широкого применения лучших мировых и отечественных достижений в области техники и технологии текстильного, швейного, мехового и кожевеннообувного производства, в том числе нанотехнологий и - продуктов.
Социальные и кадровые проблемы обусловлены состоянием качественной составляющей кадрового потенциала, которая на многих предприятиях находится в зоне критических величин, а у некоторых - уже за ними.

Ухудшающаяся ситуация в профессиональной и квалификационной подготовке рабочих кадров, низкая заработная плата и престижность труда приводят к ежегодному сокращению численности, в основном, молодых и перспективных работников в возрасте до $30-40$ лет. Только за десятилетия (с 1990 по 2008 год) численность сократилась в 3 раза, а за последующие девять лет - в 2,8 раза, что обусловило падение объемов выпуска продукции. При этом принимаемые меры по антикризисному управлению убыточных предприятий со стороны органов государственного управления и руководства не смогли повлиять на ход развития структурных диспропорций в отрасли.

$\mathrm{He}$ решение проблем данной группы существенно скажется на возможности отрасли в подъеме еe экономики и в увеличении производства конкурентоспособной продукции в объемах, необходимых для обеспечения национальной безопасности страны. Кроме того, все вышеперечисленные проблемы усугубляются воздействием мирового финансового кризиса. В условиях кризиса легкая промышленность, как никто, начинает ощущать на себе его действия. Даже те предприятия, которые за последние годы добились положительных результатов в инновационном развитии, уделяя значительное внимание модернизации производства, уже вынуждены и будут вынуждены в ближайшие годы сокращать объемы производства и отказываться от долгосрочных вложений. Это обусловлено возникшими трудностями, связанными с привлечением банковских кредитов (доля заемных средств в оборотных средствах за последние годы достигла 40 процентов), с одной стороны, увеличением объемов официального импорта, контрафактной и контрабандной продукции, падением спроса и замедлением реализации многих видов товаров, сокращением рабочих и специалистов - с другой стороны. На отдельных предприятиях стали возникать задержки с выплатой заработной платы от 2 недель до 1,5 месяцев, начались временные приостановки работы и по оценке экспертов к концу 2017 года возможно сокращение численности работающих на 10 - $15 \%$. Особенно это касается трех федеральных округов Центральный ФО, Приволжский ФО, Южный ФО, являющихся наиболее значимыми в социальном плане. Структура капитала отрасли, будучи сконцентрирована в этих округах, делает их территории наиболее критичными с точки зрения последствий углубления спада производства, что увеличивает значимость социальных последствий, 


\begin{tabular}{|c|c|c|c|c|c|c|}
\hline \multirow{4}{*}{ Impact Factor: } & ISRA (India) & $=3.117$ & SIS (USA) & $=0.912$ & ICV (Poland) & $=6.630$ \\
\hline & ISI (Dubai, UAE & $=0.829$ & РИНЦ (Russia & $=0.156$ & PIF (India) & $=1.940$ \\
\hline & GIF (Australia) & $=0.564$ & ESJI (KZ) & $=8.716$ & IBI (India) & $=4.260$ \\
\hline & $\mathrm{JIF}$ & $=1.500$ & SJIF (Morocco & $=5.667$ & OAJI (USA) & $=0.350$ \\
\hline
\end{tabular}

вытекающих от остановки производств. Доля российского товара на внутреннем рынке снизится еще в большей степени и может составить в 2018 году менее $20 \%$.

Изменить сложившуюся ситуацию можно, только разработав и реализовав антикризисные меры, направленные на активизацию инновационной деятельности, повышение эффективности производства на новом техникотехнологическом уровне и на создание благоприятных условий, обеспечивающих стабильный по годам рост объемов выпуска конкурентоспособных товаров.

Отрадно, что состоявшееся совещание 24 августа 2017 в Рязани «О мерах по развитию лёгкой промышленности» с участием представителей власти, руководителей предприятий торговли и учёных при личном участии Президента РФ В.В. Путина вынудило их - участников - дать ответы президенту на неудобные вопросы о причинах неудовлетворительного состояния лёгкой промышленности и о невыполнении тех задач, которые были сформулированы в 2013 году в г. Вологда на аналогичном совещании и практически с теми же участниками. Хочется верить, что у муниципальных, региональных и федеральных ветвей власти уменьшится синдром глухоты и желание бойкотировать выполнение ими же предложенных задач, так как обязательно президент проверит и спросит о причинах их невыполнения. Во всяком случае, такая уверенность появилась у большинства участников этого совещания, потому что президент на Восточном Экономическом Форуме, который состоялся 8 - 9 сентября 2017 года во Владивостоке на закрытом совещании в жёсткой форме, потребовал у ответственных за срыв аналогичных мероприятий по Дальнему Востоку, что спровоцировало увольнение и освобождение от должности тех должностных лиц, которые больше всего не реализовали поставленные перед ними задачи. Такая уверенность у нас обусловлена тем, что положение лёгкой промышленности архи плохо и может привести к катастрофе не только экономической, но и социальной. Все эксперты объективно высказали своё мнение на предложенные им анкеты с факторами, чтобы ответить на главный вопрос, вынесенный в заголовок - «Быть или не быть легкой промышленности?». Другое дело, что их видение по данной проблеме может быть субъективным и, конечно, имеет право быть. Но исследователь сам должен принять решение о полученных результатах априорного ранжирования, руководствуясь мнением других учёныхисследователей о идентичных проблем, сравнивая их с полученными и принимая решение о правомочности включения их в объект исследования. Такое решение требует компетентности не только самих экспертовреспондентов, но и глубокое знание о проблемах самими исследователями.

Радует тот факт, что все экспертыреспонденты единодушны в оценке роли ассортиментной политики и необходимости использования эффективных инновационных технологических решений, чтобы гарантировать производителям изготовление такой продукции, которая была бы востребована потребителями регионов ЮФО и СКФО и обеспечивала бы им получение эффективных технико-экономических показателей результатов их деятельности, а продукции - её востребованность не только на внутреннем, но что особенно важно, на зарубежных рынках. Вновь подтвердился тот факт, что имеются все основания доверять результатам априорного ранжирования, а разработанному авторами программному обеспечению по оценке компетентности участников опроса - долгую жизнь. Особенно оправдано такое использование программного обеспечения при оценке компетентности экспертов-респондентов, приглашаемые таможенными комитетами для их работы в таможенных комиссиях. Руководители таможни получают объективную оценку каждого экспертареспондента по результатам их участия в работе таможенных комиссий, так как в этом случае эксперт не может не согласиться с полученной объективной оценкой об его компетентности, а таможенные комитеты получают методику их ранжирования, отдавая предпочтение наиболее квалифицированным и объективным экспертам, чтобы обеспечить поступление на отечественные рынки продукции только высокого качества, и гарантирующие безопасность потребителю.

Хотелось бы предупредить таможенные комитеты о поспешности принятия решений о компетентности экспертов, если у них нет объективной характеристики, полученной от высококвалифицированных специалистов. Всё это предполагает корректное отношение не только к своим обязанностям, но и к приглашённым специалистам, создавая доверительную обстановку и заинтересованность в получении положительных результатов экспертизы. Если же подводить итоги об эффективности программного обеспечения для оценки компетентности участвующих в опросе респондентов, то исследователь имеет инструмент для выбора тех респондентов, мнение которых имеет высокую степень доверия, подтверждённую значением коэффициента конкордации $(W)$, которое стремится к единице. Таким образом, подводя итоги об эффективности априорного ранжирования и разработанного авторами программного обеспечения, можно с 


\begin{tabular}{|c|c|c|c|c|c|c|}
\hline \multirow{4}{*}{ Impact Factor: } & ISRA (India) & $=3.117$ & SIS (USA) & $=0.912$ & ICV (Poland) & $=6.630$ \\
\hline & ISI (Dubai, UAE & $=0.829$ & РИНЦ (Russia & $=0.156$ & PIF (India) & $=1.940$ \\
\hline & GIF (Australia) & $=0.564$ & ESJI (KZ) & $=8.716$ & IBI (India) & $=4.260$ \\
\hline & JIF & $=1.500$ & SJIF (Morocco & $=5.667$ & OAJI (USA) & $=0.350$ \\
\hline
\end{tabular}

уверенностью гарантировать всем заинтересованным сторонам достижения тех результатов, которые они ожидают, но при условии, что на всех этапах опроса и исследователь, и участники солидарны в главном: добиться таких результатов, которые были бы объективно значимыми и достоверными при проведении дальнейших исследований.

Дорожная карта реализаџии стратегии развития легкой промышленности до 2025 года

В рамках плана реализации Стратегии предусмотрены сквозные мероприятия, реализуемые в течение всего периода действия Стратегии:

- поддержка создания и развития российских брендов одежды и обуви;

- борьба с нелегальным и незаконным оборотом товаров легкой промышленности;

- стимулирование экспорта в конкурентоспособных сегментах легкой промышленности;

- сохранение кожевенных сырьевых ресурсов для собственного производства кожи и обуви; отрасли;

- формирование кадрового потенциала

- стимулирование НИОКР и трансфера технологий;

- информационная и маркетинговая поддержка развития отрасли;

- мониторинг эффективности реализации стратегии и корректировка плана

кроме того, ряд стратегических инициатив будет реализован поэтапно:

Этаn 1. Основные мероприятия реализуются в период 2015 - 2017 гг.:

○ подготовка к реализации стратегии;

○ стимулирование развития производства синтетического текстиля (синтетические ткани);

○ стимулирование роста потребления технического текстиля;

○ создание эко системы предприятий по производству технического текстиля и нетканых материалов в рамках кластеров / индустриальных парков;

○ стимулирование спроса на специальную и защитную одежду и обувь;

○ создание льготных условий для контрактного швейного и обувного производства;

○ переориентация швейного производства на конкурентоспособные продукты с наличием выгодного доступа к материалам и низкой долей ручного труда;

○ поддержка создания производственной инфраструктуры в рамках кластера обувной промышленности;
○ обеспечение выгодного доступа производителей к функциональным компонентам одежды и обуви;

○ стимулирование производства автомобильных кож и повышения степени локализации авто компонентов.

Этап 2. Основные мероприятия реализуются в период $2018-2022$ гг.:

- формирование спроса на химические волокна;

- поддержка проектов по локализации производства химических волокон;

- стимулирование переработки отходов кожевенного производства и внедрения новых технологий по повышению экологической безопасности производства.

Эman 3. Мониторинг результатов и реализация сквозных инициатив в период $2023-2025$ гг.

Детальный план реализации Стратегии с указанием перечня мероприятий, ожидаемых результатов, сроков и ответственных представлен в табл. 3.1.

Если покупательская удовлетворенность формируется за счет уровня производителя, т.е. его тестовый уровень формируется ценовой доступностью товара, который предлагается ассортиментным рядом, естественно, качеством, и за счет уровня потребителя, т.е. его тестовый уровень предполагает наличие культуры обслуживания покупателей, привлекательностью товара, покупательской удовлетворенностью, и, конечно, платежеспособностью самих потребителей, то респонденты, принявшие участие в опросе, считают, что потребительская удовлетворенность будет обеспечиваться при надежности товара, его ценовой доступностью, наличия у покупателей возможности совершать покупки, т.е. их платежеспособностью. Естественное качество продукции, разнообразие ассортиментного ряда, привлекательность решением дизайна, т.е. соответствовать моде, продукция должна иметь достаточно продолжительный гарантийный срок, и что интересно, все респонденты единодушны в том, чтобы производители боролись за уважительное отношение к ним покупателей, завоёвывать их доверие и желание совершать покупку именно продукции этих предприятий, т.е. бренд и имидж остаются востребованными всегда, что в совокупности решает основную задачу обеспечивает потребителей отечественной продукцией в рамках импортозамещения.

Критерии оценки конкурентоспособности предприятия легкой промышленности с помощью разработанного авторами программного обеспечения впервые позволили формализовать роль экспертов - респондентов по признаку их компетентности к рассматриваемой проблеме. 


\begin{tabular}{|c|c|c|c|c|c|c|}
\hline \multirow{4}{*}{ Impact Factor: } & ISRA (India) & $=\mathbf{3 . 1 1 7}$ & SIS (USA) & $=0.912$ & ICV (Poland) & $=6.630$ \\
\hline & ISI (Dubai, UAE & $=0.829$ & РИНЦ (Russia & $=0.156$ & PIF (India) & $=1.940$ \\
\hline & GIF (Australia) & $=0.564$ & ESJI (KZ) & $=8.716$ & IBI (India) & $=4.260$ \\
\hline & JIF & $=1.500$ & SJIF (Morocco & $=5.667$ & OAJI (USA) & $=0.350$ \\
\hline
\end{tabular}

Необходимость в таком подходе обусловлена желанием иметь объективную оценку компетентности с учетом не только мнения

приглашаемой стороной экспертов-респондентов к участию в опросе, но и с помощью оценочного

Таблица 3.1. Стратегия развития легкой промышленности России на период до 2025 года.

\begin{tabular}{|c|c|}
\hline $\begin{array}{l}\text { Наименование } \\
\text { стратегии: }\end{array}$ & $\begin{array}{c}\text { Стратегия развития легкой промышленности } \\
\text { России на период до } 2025 \text { года }\end{array}$ \\
\hline $\begin{array}{l}\text { Наименование, дата } \\
\text { и номер } \\
\text { нормативного акта } \\
\text { о подготовке } \\
\text { Стратегии }\end{array}$ & $\begin{array}{l}\text { Поручение Президента Российской Федерации от } 3 \text { июля } 2008 \text { года № Пр-1369 и } \\
\text { поручение Правительства Российской Федерации от } 15 \text { июля } 2008 \text { года } \\
\text { № ВП-П9-4244. и с учетом новых поручений президента РФ по итогам совещания «О } \\
\text { мерах по развитию легкой промышленности в Российской Федерации», состоявшегося } 24 \\
\text { августа } 2017 \text { года в г. Рязани }\end{array}$ \\
\hline $\begin{array}{l}\text { Наименование } \\
\text { стратегии: }\end{array}$ & $\begin{array}{c}\text { Стратегия развития легкой промышленности } \\
\text { России на период до } 2025 \text { года }\end{array}$ \\
\hline $\begin{array}{c}\text { Разработчик } \\
\text { Стратегии }\end{array}$ & $\begin{array}{l}\text { Министерство промышленности и торговли } \\
\text { Российской Федерации }\end{array}$ \\
\hline $\begin{array}{c}\text { Системные } \\
\text { социально- } \\
\text { экономические } \\
\text { проблемы, } \\
\text { решаемые } \\
\text { Стратегией }\end{array}$ & $\begin{array}{l}\text { Техническая и технологическая отсталость легкой промышленности от зарубежных стран, } \\
\text { выражаемая в высокой энергоемкости, сырьё ёмкости и трудоёмкости производства. } \\
\text { Низкий уровень инновационной и инвестиционной деятельности отрасли, выражаемый в слабой } \\
\text { конкурентоспособности отечественных товаров, в низкой доле инновационнй продукции. } \\
\text { Высокий удельный вес теневой экономики, ставший причиной усиления стратегической и } \\
\text { товарной зависимости государства от зарубежных стран. } \\
\text { Отсутствие цивилизованного рынка потребительских товаров, выражаемое в обострении } \\
\text { конкуренции на внутреннем рынке между российскими и зарубежными } \\
\text { товаропроизводителями. } \\
\text { Социальная и кадровая проблема, проявляющаяся в ежегодном (примерно на } 10 \text { \%) оттоке } \\
\text { рабочих кадров }\end{array}$ \\
\hline $\begin{array}{l}\text { Цели и задачи } \\
\text { Стратегии }\end{array}$ & $\begin{array}{l}\text { Цели: интенсификация инновационного развития и технологического прорыва } \\
\text { текстильной и легкой промышленности России, обеспечение эффективного соответствия } \\
\text { объемов производства, качества и ассортимента продукции совокупному спросу } \\
\text { российского и мирового рынков, повышения национальной значимости отрасли и ее } \\
\text { имиджа в мировом сообществе. } \\
\text { Основные задачи: } \\
\text { - повышение конкурентного уровня материально-технической базы на основе } \\
\text { технического перевооружения и модернизации производства, внедрения прорывных } \\
\text { технологий и создания новых высокопроизводительных производств, обеспечивающих } \\
\text { решение проблем технологической и товарной зависимости отрасли от зарубежных стран; } \\
\text { - повышение конкурентоспособности и увеличение объемов выпуска наукоемкой } \\
\text { продукции; } \\
\text { - усиление борьбы с теневым производством и с несанкционированным импортом с целью } \\
\text { увеличения доли российских товаров на внутреннем рынке к 2020 году минимум до } 50 \text { \%, } \\
\text { повышения экономической и стратегической безопасности государства. } \\
\text { - обеспечение к 2020 году роста экспорта продукции в 4,2 раза, объем которого может составить } \\
\text { более } 3,5 \text { млрд. долл. США, вовлечение организаций легкой промышленности в международное } \\
\text { разделение труда; } \\
\text { - разработка эффективных механизмов стимулирования инвестиционной и } \\
\text { инновационной активности, повышения эффективности НИОКР и развитие наукоемких } \\
\text { производств; } \\
\text { - создание основы для углубления процессов кооперации, интеграции и развития } \\
\text { межтерриториальной и межотраслевой организации взаимодействия субъектов науки, } \\
\text { промышленности и малого предпринимательства; } \\
\text { - формирование цивилизованного потребительского рынка и рыночной инфраструктуры, } \\
\text { развитие межрегиональной и межотраслевой товаропроводящей сети, коммерческих } \\
\text { связей со странами ближнего и дальнего зарубежья; } \\
\text { - развитие системы воспроизводства трудовых ресурсов, подготовки и переподготовки } \\
\text { рабочих, менеджеров и управленческих кадров, способных умело вести производство и } \\
\text { бизнес в условиях открытого рынка. }\end{array}$ \\
\hline
\end{tabular}




\begin{tabular}{|c|c|c|c|c|c|c|}
\hline \multirow{4}{*}{ Impact Factor: } & ISRA (India) & $=3.117$ & SIS (USA) & $=0.912$ & ICV (Poland) & $=6.630$ \\
\hline & ISI (Dubai, UAE & $=0.829$ & РИНЦ (Russia & $=0.156$ & PIF (India) & $=1.940$ \\
\hline & GIF (Australia) & $=0.564$ & ESJI (KZ) & $=8.716$ & IBI (India) & $=4.260$ \\
\hline & JIF & $=1.500$ & SJIF (Morocco & $=5.667$ & OAJI (USA) & $=0.350$ \\
\hline
\end{tabular}

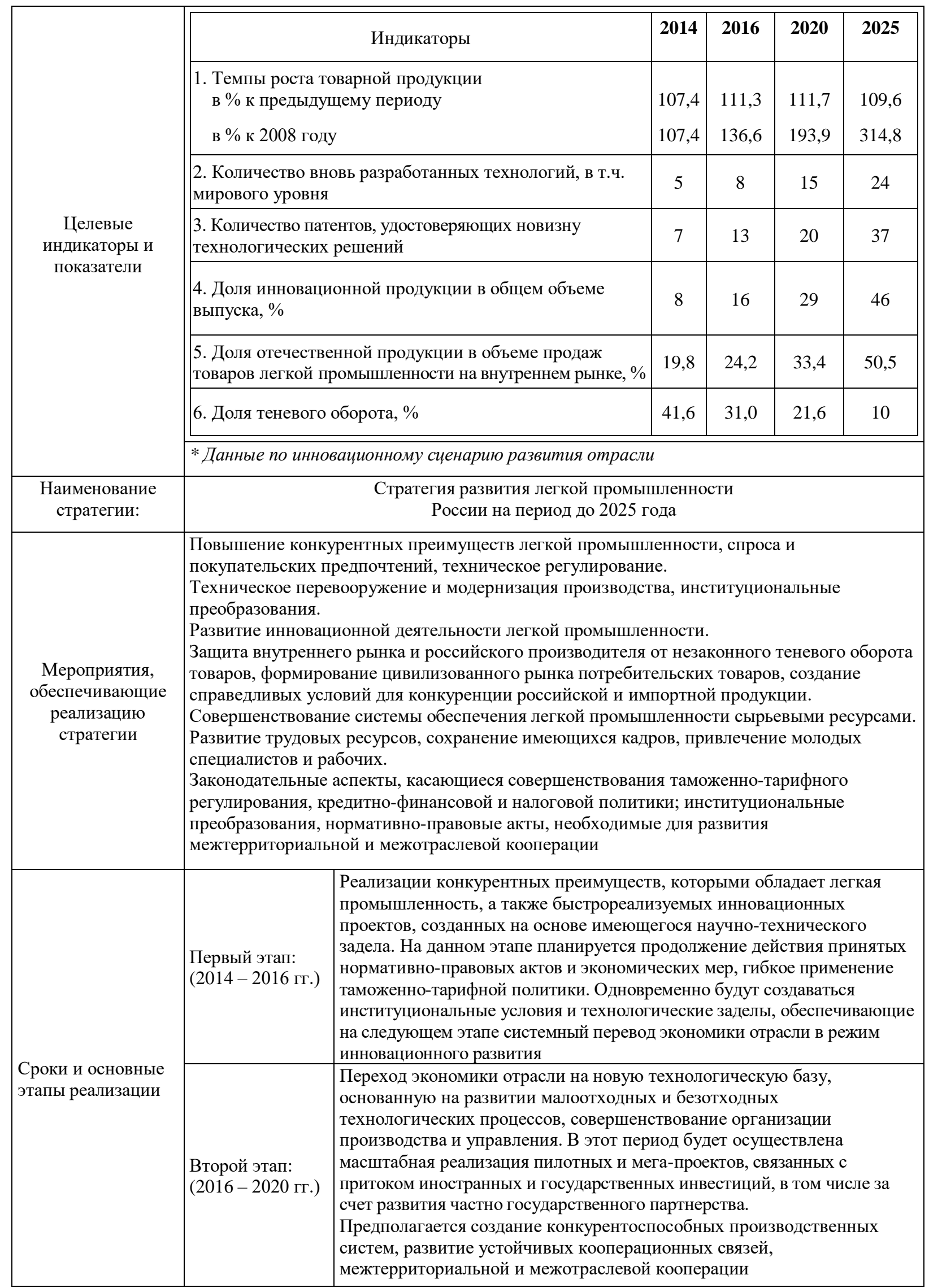




\begin{tabular}{|c|c|c|c|c|c|c|}
\hline \multirow{4}{*}{ Impact Factor: } & ISRA (India) & $=3.117$ & SIS (USA) & $=0.912$ & ICV (Poland) & $=6.630$ \\
\hline & ISI (Dubai, UAE & $=0.829$ & РИНЦ (Russia) & $=0.156$ & PIF (India) & $=1.940$ \\
\hline & GIF (Australia) & $=0.564$ & ESJI (KZ) & $=8.716$ & IBI (India) & $=4.260$ \\
\hline & JIF & $=1.500$ & SJIF (Morocco) & $=5.667$ & OAJI (USA) & $=0.350$ \\
\hline
\end{tabular}

\begin{tabular}{|c|c|c|c|}
\hline & $\begin{array}{l}\text { Третий этап: } \\
(2021-2025 \text { гг.) }\end{array}$ & \multicolumn{2}{|c|}{$\begin{array}{l}\text { Фаза выхода отрасли на заданную динамику инвестиционной и } \\
\text { инновационной активности, достижение целей и экономических } \\
\text { показателей Стратегии. Будут созданы основы для сокращения разрыва } \\
\text { отрасли в технологическом развитии от зарубежных стран, для } \\
\text { увеличения ее вклада в ВВП к } 2020 \text { году не менее чем в 2,0 раза, для } \\
\text { повышения национальной значимости и имиджа отрасли в мировом } \\
\text { сообществе. }\end{array}$} \\
\hline $\begin{array}{c}\text { Объемы и } \\
\text { источники } \\
\text { финансирования }\end{array}$ & \multicolumn{2}{|c|}{$\begin{array}{l}\text { Затраты на реализацию Стратегии, всего } \\
\text { в том числе: } \\
\text { - собственные средства } \\
\text { - привлеченные средства } \\
\text { - средства федерального бюджета } \\
\text { - средства субъектов федерации }\end{array}$} & $\begin{array}{l}\text { 145,63 млрд. руб. } \\
\text { 65,22 млрд. руб. } \\
\text { 62,91 млрд. руб. } \\
\text { 10,96 млрд. руб. } \\
\text { 6,54 млрд. руб. }\end{array}$ \\
\hline $\begin{array}{l}\text { Распределение } \\
\text { средств }\end{array}$ & $\begin{array}{l}\text { Субсидии, всего, } \\
\text { в т.ч. на возмеще } \\
\text { закупку сырья } \\
\text { техническое пере } \\
\text { стимулирование } \\
\text { средства на реаль } \\
\text { средства на технг } \\
\text { средства на реаль } \\
\text { затраты на НИОІ }\end{array}$ & $\begin{array}{l}\text { ие процентных ставок по привлеченным кредитам на: } \\
\text { вооружение } \\
\text { кспортеров товаров } \\
\text { зацию пилотных инвестиционных проектов } \\
\text { ческое перевооружение } \\
\text { зацию ВИП-проектов } \\
\text { P }\end{array}$ & $\begin{array}{l}\text { 8,92 млрд. руб. } \\
\text { 4,44 млрд. руб. } \\
\text { 3,52 млрд. руб. } \\
\text { 0,96 млрд. руб. } \\
\text { 44,32 млрд. руб. } \\
\text { 89,05 млрд. руб. } \\
\text { 1,58 млрд. руб. } \\
\text { 1,75 млрд. руб. }\end{array}$ \\
\hline $\begin{array}{l}\text { Наименование } \\
\text { стратегии: }\end{array}$ & \multicolumn{3}{|c|}{$\begin{array}{c}\text { Стратегия развития легкой промышленности } \\
\text { России на период до } 2025 \text { года } \\
\end{array}$} \\
\hline & \multicolumn{3}{|c|}{ 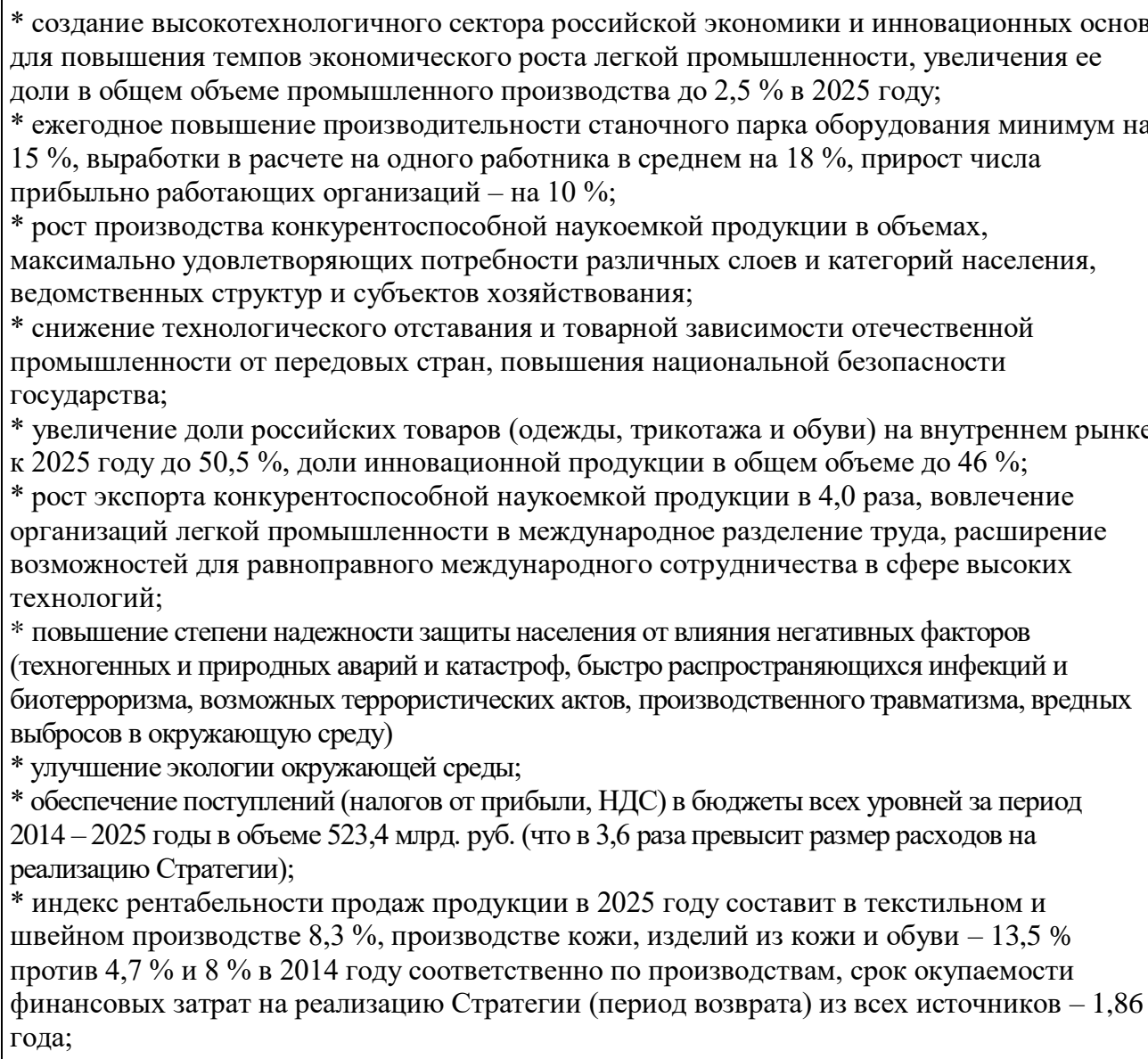 } \\
\hline
\end{tabular}




\begin{tabular}{|c|c|c|c|c|c|c|}
\hline \multirow{4}{*}{ Impact Factor: } & ISRA (India) & $=3.117$ & SIS (USA) & $=0.912$ & ICV (Poland) & $=6.630$ \\
\hline & ISI (Dubai, UAE & $=0.829$ & РИНЦ (Russia & $=0.156$ & PIF (India) & $=1.940$ \\
\hline & GIF (Australia) & $=0.564$ & ESJI (KZ) & $=8.716$ & IBI (India) & $=4.260$ \\
\hline & JIF & $=1.500$ & SJIF (Morocco & $=5.667$ & OAJI (USA) & $=0.350$ \\
\hline
\end{tabular}

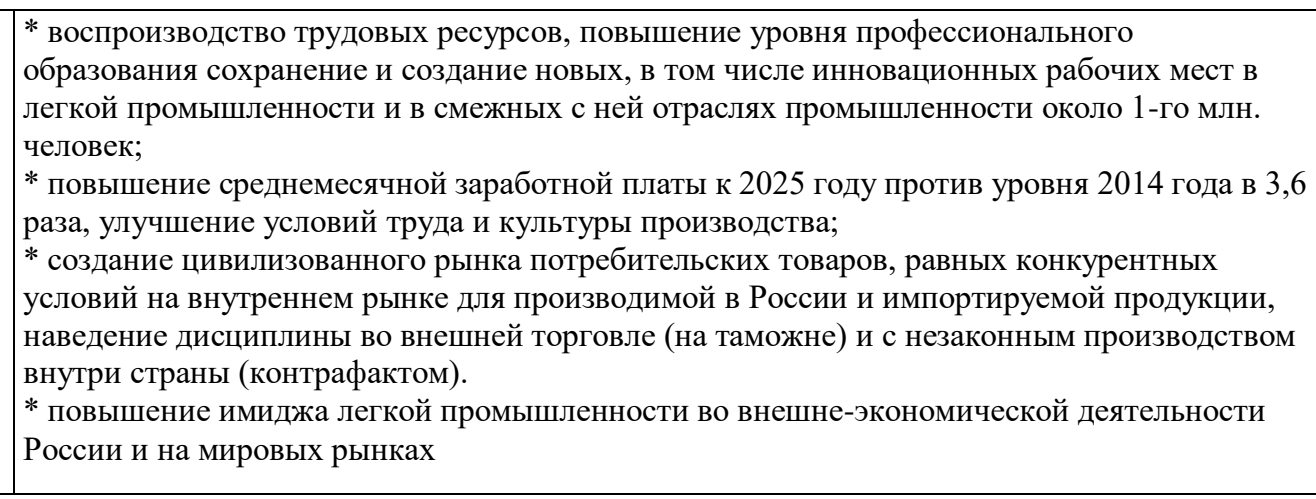

Результаты опроса экспертов по оценке конкурентоспособности предприятия и конкурентоспособности товара легкой промышленности (табл. 3.2) хотя и получили значение коэффициента конкордации $(W)$ в пределах $0,4-0,6$, но исключив еретиков, то есть тех респондентов, мнение которых не совпадают с мнением большинства других экспертов, мы обнаружили приятный факт, что мнение и тех респондентов, чей авторитет не вызывает сомнений, и тех которых программа отнесла к еретикам, имеют однозначное или близкое мнение, что факторы, характеризующие их влияние на конкурентоспособность предприятия и конкурентоспособность товара идентичны, и они могут использоваться в дальнейших исследованиях при оценки этой самой конкурентоспособности предприятий, предполагая, что ему по силах изготавливать импортозамещающую продукцию для потребителей регионов ЮФО и СКФО. При этом, производители имеют все основания эти критерии, а именно: соотношение качества товара и издержек его производства и маркетинга; темпы роста объёма продаж; затраты на инновации; производительность труда; уровень партнерских отношений заинтересованными участниками производства импортозамещаемой продукции; затраты на 1 рубль реализованной продукцией, и главным критерием; средневзвешенной по товарному ассортименту конкурентоспособностью товара считать востребованными.

Но при этом все эксперты-респонденты были единодушны в том, что конкурентоспособность предприятия будет стабильнее во времени, если доля предприятия на рынке спроса будет стабильной. Во всяком случае не будет уменьшаться во времени, если будет ему гарантирована доходность инвестиций и, конечно, обеспечиваться устойчивая рентабельность совокупных активов легкой промышленности, занятых производством импортозамещаемой продукцией. Оправдано мнение всех экспертов, что на конкурентоспособность предприятия влияет и устойчивый товарооборот на основе прямых договорных связей с реализаторами продукции этих самый предприятий.

Согласны мы с ними и в вопросе о роли высококвалифицированных кадров, что, конечно, хотя и нашло свое отражение в опросном листе в виде одного критерия - коэффициента текучести кадров - но не вызвало у экспертов, к сожалением, озабоченности из-за ликвидации лицеев, колледжей, на базе которых и готовили высококвалифицированных рабочих и руководителей среднего звена - мастеров, техников, механиков, технологов, занятых обслуживанием не только инновационного технологического процесса, но и инновационного оборудования. Практически прекратилась подготовка инженерно-технических кадров, мотивировалось всё это отсутствием в их востребованности, хотя сами руководители предприятий в недоумении. Есть и оборотная сторона этой ситуации, а именно - что руководители устранились от подготовки этих самых высококвалифицированных специалистов через целевую подготовку в колледжах и в вузах, не желая нести затраты на эту самую подготовку, забывая русскую пословицу: «Скупой платит дважды». Огорчителен и тот факт, что большинство руководителей предприятий считают, что все само собой разрешится, но если сапожника, швею-мотористку, скорняжника можно подготовить на рабочих местах, то подготовить ведущего инженера - руководителя и организатора производства для наполненных технологических процессов с эффективным инновационным решением, маловероятно.

Таблица 3.2. Результаты опроса респондентов о влиянии факторов на конкурентоспособность предприятия и конкурентоспособность товара.

Факторы $\quad$ Характеристика участников опроса




\begin{tabular}{|c|c|c|c|c|c|c|}
\hline \multirow{4}{*}{ Impact Factor: } & ISRA (India) & $=3.117$ & SIS (USA) & $=0.912$ & ICV (Poland) & $=6.630$ \\
\hline & ISI (Dubai, UAE & $=0.829$ & РИНЦ (Russia) & $=0.156$ & PIF (India) & $=1.940$ \\
\hline & GIF (Australia) & $=0.564$ & ESJI (KZ) & $=8.716$ & IBI (India) & $=4.260$ \\
\hline & JIF & $=1.500$ & SJIF (Morocco & $=5.667$ & OAJI (USA) & $=0.350$ \\
\hline
\end{tabular}

\begin{tabular}{|c|c|c|c|c|c|c|c|c|}
\hline & \multicolumn{4}{|c|}{ Мнение участников опроса с еретиками } & \multicolumn{4}{|c|}{$\begin{array}{c}\text { Мнение участников опроса без еретиков, т.е. мнение } \\
\text { которых не совпадает с большинством участников } \\
\text { опроса }\end{array}$} \\
\hline & Студенты & Специалисты & $\begin{array}{c}\text { Все } \\
\text { участники } \\
\text { опроса }\end{array}$ & \begin{tabular}{|} 
Согласованное \\
мнение \\
респондентов
\end{tabular} & Студенты & Специалисты & $\begin{array}{c}\text { Все } \\
\text { участники } \\
\text { опроса }\end{array}$ & $\begin{array}{l}\text { Согласованное } \\
\text { мнение } \\
\text { респондентов }\end{array}$ \\
\hline 1 & 1 & 1 & 1 & 1 & 3 & 1 & 3 & 3 \\
\hline 2 & 2 & 4 & 2 & 2 & 1 & 6 & 1 & 1 \\
\hline 3 & 4 & 6 & 4 & 4 & 4 & 11 & 4 & 4 \\
\hline 4 & 3 & 3 & 3 & 3 & 2 & 7 & 2 & 2 \\
\hline 5 & 6 & 23 & 7 & 6 & 10 & 16 & 10 & 10 \\
\hline 6 & 7 & 8 & 6 & 7 & 12 & 3 & 12 & 12 \\
\hline 7 & 9 & 13 & 9 & 9 & 6 & 26 & 6 & 6 \\
\hline 8 & 12 & 22 & 14 & 8 & 11 & 8 & 11 & 11 \\
\hline 9 & 5 & 15 & 5 & 5 & 7 & 27 & 7 & 7 \\
\hline 10 & 13 & 16 & 19 & 16 & 5 & 13 & 5 & 5 \\
\hline 11 & 16 & 17 & 18 & 17 & 8 & 18 & 8 & 8 \\
\hline 12 & 26 & 28 & 27 & 10 & 13 & 28 & 13 & 13 \\
\hline 13 & 10 & 11 & 11 & 11 & 16 & 9 & 16 & 16 \\
\hline 14 & 20 & 27 & 25 & 27 & 15 & 23 & 15 & 15 \\
\hline 15 & 8 & 26 & 13 & 13 & 17 & 20 & 17 & 17 \\
\hline 16 & 31 & 21 & 31 & 31 & 21 & 19 & 21 & 21 \\
\hline 17 & 11 & 15 & 12 & 12 & 18 & 2 & 18 & 18 \\
\hline 18 & 13 & 5 & 8 & 14 & 19 & 4 & 19 & 19 \\
\hline 19 & 21 & 31 & 26 & 15 & 20 & 31 & 20 & 20 \\
\hline 20 & 15 & 20 & 20 & 18 & 22 & 29 & 22 & 23 \\
\hline 21 & 14 & 18 & 16 & 20 & 24 & 10 & 24 & 24 \\
\hline
\end{tabular}

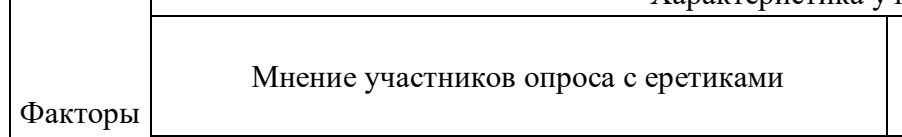

\begin{tabular}{|c|c|c|c|c|}
\hline \multirow[t]{2}{*}{ Факторы } & & & & \\
\hline & Студенты & Специалисты & $\begin{array}{c}\text { Все } \\
\text { участники } \\
\text { опроса }\end{array}$ & $\begin{array}{c}\text { Согласованное } \\
\text { мнение } \\
\text { респондентов }\end{array}$ \\
\hline
\end{tabular}

Мнение участников опроса без еретиков, т.е. мнение которых не совпадает с большинством участников опроса

\begin{tabular}{|c|c|c|c|c|c|c|c|c|}
\hline & Студ & Спец & $\begin{array}{c}\text { Участники } \\
\text { опроса }\end{array}$ & респондентов & С уден & слециалист & 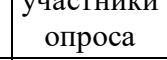 & респондентов \\
\hline 22 & 29 & 24 & 28 & 28 & 26 & 22 & 26 & 25 \\
\hline 23 & 27 & 29 & 30 & 21 & 25 & 21 & 25 & 26 \\
\hline 24 & 19 & 25 & 22 & 19 & 23 & 25 & 23 & 22 \\
\hline 25 & 23 & 10 & 21 & 23 & 27 & 5 & 27 & 27 \\
\hline 26 & 18 & 14 & 15 & 24 & 14 & 17 & 14 & 14 \\
\hline 27 & 24 & 9 & 17 & 25 & 28 & 24 & 28 & 28 \\
\hline 28 & 25 & 19 & 24 & 26 & 29 & 30 & 29 & 29 \\
\hline 29 & 30 & 12 & 29 & 29 & 30 & 15 & 30 & 30 \\
\hline 30 & 28 & 7 & 23 & 30 & 31 & 12 & 31 & 31 \\
\hline 31 & 22 & 2 & 10 & 22 & 9 & 14 & 9 & 9 \\
\hline
\end{tabular}

Наиболее значимыми факторами респондентами были обозначены:

$\mathrm{X}_{1}$ - Соотношение качества товара и издержек его производства и маркетинга
$\mathrm{X}_{2}$ - Производительность труда

$\mathrm{X}_{4}$ - Затраты на 1 рубль реализованной продукции 


\begin{tabular}{|c|c|c|c|c|c|c|}
\hline \multirow{4}{*}{ Impact Factor: } & ISRA (India) & $=3.117$ & SIS (USA) & $=0.912$ & ICV (Poland) & $=6.630$ \\
\hline & ISI (Dubai, UAE & $=0.829$ & РИНЦ (Russia & $=0.156$ & PIF (India) & $=1.940$ \\
\hline & GIF (Australia) & $=0.564$ & ESJI (KZ) & $=8.716$ & IBI (India) & $=4.260$ \\
\hline & JIF & $=1.500$ & SJIF (Morocco & $=5.667$ & OAJI (USA) & $=0.350$ \\
\hline
\end{tabular}

$\mathrm{X}_{3} \quad-\quad$ Коэффициент опережения производительности труда по отношению к росту заработной платы

$\mathrm{X}_{9}$ - Прибыль единицы реализованной продукции

$\mathrm{X}_{5}$ - Средневзвешенная по товарному ассортименту конкурентоспособность товара

$\mathrm{X}_{6}-$ Количество ассортиментных групп на предприятии

$\mathrm{X}_{8}$ - Степень удовлетворённости каждой ассортиментной группы

$\mathrm{X}_{7}$ - Доля ассортиментной группы в общем объёме производства

$\mathrm{X}_{13} \quad-\quad$ Безубыточность единицы реализованной продукции

$\mathrm{X}_{17}$ - Оценка уровня партнёрских отношений с заинтересованными сторонами предприятия

Значимые факторы, обозначенные экспертами:

$\mathrm{X}_{10}$ - Условно-переменные затраты на единицу реализуемой продукции

$\mathrm{X}_{11}$ - Условно-постоянные расходы на единицу реализованной продукции

$\mathrm{X}_{12}$ - Весомость суммарной расценки на единицу реализуемой продукции

$\mathrm{X}_{15}$ - Темп роста объёмов продаж

$\mathrm{X}_{18}$ - Доля предприятия на рынке

$\mathrm{X}_{19}$ - Доходность инвестиций

$\mathrm{X}_{20}$ - Рентабельность совокупных активов

$\mathrm{X}_{21}$ - Затраты на инновации

$\mathrm{X}_{24}$ - Материалоотдача

Не значимыми респонденты назвали следуюшие факторы:

$\mathrm{X}_{14}$ - Запас финансовой прочности от объёма реализуемой продукции

$\mathrm{X}_{16}$ - Превышение допустимого уровня запасов готовой продукции

$\mathrm{X}_{22}$ - Коэффициент обеспеченности собственными средствами

$\mathrm{X}_{23}$ - Коэффициент использования производственных мощностей

$\mathrm{X}_{25}$ - Доля сертифицированной продукции в соответствии с международными стандартами серии ИСО

$\mathrm{X}_{26}$ - Снижение уровня материалоёмкости

$\mathrm{X}_{27}$ - Доля инновационных товаров

$\mathrm{X}_{28}$ - Товарооборот, допускающий прямые связи

$\mathrm{X}_{29} \quad-\quad$ Коэффициент равномерного поступления товара на рынки сбыта

$\mathrm{X}_{30}-$ Износ основных средств

$\mathrm{X}_{31}-$ Коэффициент текучести кадров

Не существует ни одного предприятия, которое не имело бы внешнего окружения и не находилось бы с ним в состоянии постоянного взаимодействия. Любое предприятие нуждается в регулярном получении из внешней среды исходных продуктов для обеспечения своей жизнедеятельности. При этом каждое предприятие должно отдавать что-то во внешнюю среду в качестве компенсации за ее существование. Как только рвутся связи с внешней средой, предприятие погибает. В последнее время в связи с усилением и усложнением конкуренции, а также резким ускорением процессов изменения в окружающей среде предприятия всё в большей мере вынуждены уделять внимание вопросам взаимодействия с окружением, всё в большей мере развивать способности адаптации к изменениям внешней среды.

Ключевую роль в выработке и проведении политики взаимодействия предприятия с окружением играет менеджмент, особенно его верхний уровень. Вопросы долгосрочной стратегии взаимодействия предприятия со средой становятся во главу угла построения всех процессов управления. Менеджмент уже не занимается только внутренними вопросами предприятия. В равной, а может быть и в большей мере его взор направлен за пределы предприятия. Менеджмент старается строить эффективное взаимодействие предприятия с окружением не только путем воздействия на процессы, происходящие в предприятии, но и путем воздействия на окружающую среду. Стратегическое управление, решающее эти задачи, выдвигается на первый план в комплексе процессов управления предприятием. Внешнее окружение предприятия, состояние взаимодействия с которым определяется преимущественно качеством управления им, можно представить в виде двух сфер.

Первая сфера - это общее внешнее окружение предприятия. Данное внешнее окружение отражает состояние общества, его экономики, природной среды и не связано непосредственно с конкретным, предприятием. Общее внешнее окружение является более или менее одинаковым для подавляющего большинства предприятий.

Вторая сфера - это так называемое непосредственное деловое окружение предприятия. Это окружение формируют такие субъекты среды, которые непосредственно связаны или непосредственно воздействуют на деятельность данной конкретного предприятия. При этом важно подчеркнуть, что и предприятие в свою очередь может непосредственно влиять на них.

Общее внешнее окружение формируется под влиянием политических, правовых, социальнокультурных, экономических, технологических, национальных и международных процессов, а также процессов природопользования.

Непосредственное деловое окружение предприятия создают покупатели, поставщики, 


\begin{tabular}{|c|c|c|c|c|c|c|}
\hline \multirow{4}{*}{ Impact Factor: } & ISRA (India) & $=3.117$ & SIS (USA) & $=0.912$ & ICV (Poland) & $=6.630$ \\
\hline & ISI (Dubai, UAE & $=0.829$ & РИНЦ (Russia & $=0.156$ & PIF (India) & $=1.940$ \\
\hline & GIF (Australia) & $=0.564$ & ESJI (KZ) & $=8.716$ & IBI (India) & $=4.260$ \\
\hline & JIF & $=1.500$ & SJIF (Morocco & $=5.667$ & OAJI (USA) & $=0.350$ \\
\hline
\end{tabular}

конкуренты, деловые партнеры, а также регулирующие службы и такие организации, как административные органы, деловые объединения и ассоциации, профсоюзы и т.п.

Управляя процессами взаимодействия предприятия с окружающей средой, менеджмент сталкивается с рядом серьезных проблем, порождаемых неопределенностью в состоянии окружающей среды. В связи с этим одной из сложнейших задач, стоящих перед менеджментом, является снижение неопределенности положения предприятия в окружении. Это достигается путем развития его адаптивности к внешней среде и установления широких связей с окружением, позволяющих предприятию органично вписываться в окружающую среду.

В зависимости от того, насколько предприятие адаптивно к изменениям в окружении, выделяется два типа управления предприятием:

1) механистический тип управления; 2) органический тип управления.

Механистический тип управления предприятием характеризуется набором следующих характеристик:

- консервативная, негибкая структура;

- четко определенные, стандартизированные и устойчивые задачи;

- сопротивление изменениям;

- власть проистекает из иерархических уровней в организации и из позиции в организации;

- иерархическая система контроля;

- командный тип коммуникаций, идущих сверху вниз;

- содержанием

коммуникаций преимущественно являются распоряжения, инструкции и принятые руководством решения.

Управлению органического типа характерно:

- гибкая структура;

- динамичные, не жестко определенные задачи;

- готовность к изменениям;

- власть базируется на знании и опыте;

- самоконтроль и контроль коллег;

- многонаправленность коммуникаций (вертикальные, горизонтальные, диагональные и др.);

- содержанием коммуникаций являются информация и советы.

Каждый из данных типов имеет определенные преимущества. Соответственно каждому из данных типов может быть дано определенное предпочтение в зависимости от характера окружения и уровня неопределенности. В том случае, если окружение динамично, если высок уровень неопределенности, более эффективным является органический тип управления предприятием. Если же окружение стабильно и неопределенность находится на низком уровне, предпочтение может быть отдано механистическому типу управления.

Развитие взглядов на управление: «одномерные» и «синтетические» учения:

Приступая к анализу развития учения об управлении, следует помнить о том, что основная задача управления - координация усилий всех элементов предприятия в деле осуществления успешности его функционирования.

Полезно обратить внимание на строение внутренней среды организации, выделяя такие элементы, как цели, кадры, задачи, технологии и структуры.

Надо помнить и о наличии внешней среды предприятия, четко понимая, что именно оно открывает доступ к ресурсам и, тем самым определяет возможность его существования.

Совершенно недопустимо забывать при этом о том, что «человек думает, потому, что он делает». И, хотя сама мысль не подвластна времени, ее материализация, осуществляется во времени и пространстве и, самое главное, требует затрат энергии. Другими словами, развитие мысли реально возможно только при наличии опыта ее реализации.

Практика управления также стара, как и предприятие. На глиняных табличках, датированных третьим тысячелетием до нашей эры, записаны сведения о коммерческих сделках и законах древней Шумерии.

Будем иметь в виду: задача - это цель в конкретных условиях. Задача (задание) - это предписанная работа, серия работ или часть работы, которая должна быть выполнена заранее установленным способом в заранее оговоренные сроки. Задачи предписываются должности, а не работнику.

Взгляды на управление развивались по мере того, как развивались общественные отношения, совершенствовалась технология производства, появлялись новые средства связи и обработки информации. Однако управленческая мысль всегда знаменовала собой рубежи, начиная с которых происходили широкие преобразования в практику управления.

Управленческая мысль постоянно обращается к сфере самой коллективной деятельности или деятельности управления. Если в первой выделить субъектный и объектный планы, то получим три области внимания и поисков: задачи, люди и управленческая деятельность. Для начальной стадии развития науки об управлении было характерно акцентирование внимания на одной из них (одномерные учения), в последующем охват количества изучаемых факторов увеличивался (многомерные, синтетические учения). К настоящему времени эти две группы важнейших 


\begin{tabular}{|c|c|c|c|c|c|c|}
\hline \multirow{4}{*}{ Impact Factor: } & ISRA (India) & $=3.117$ & SIS (USA) & $=0.912$ & ICV (Poland) & $=6.630$ \\
\hline & ISI (Dubai, UAE & $=0.829$ & РИНЦ (Russia) & $=0.156$ & PIF (India) & $=1.940$ \\
\hline & GIF (Australia) & $=0.564$ & ESJI (KZ) & $=8.716$ & IBI (India) & $=4.260$ \\
\hline & JIF & $=1.500$ & SJIF (Morocco & $=5.667$ & OAJI (USA) & $=0.350$ \\
\hline
\end{tabular}

подходов достаточно развиты и представляют совместно системно определившуюся науку об управлении.

«Одномерные» учения об управлении. К числу наиболее заметных учений этой группы можно отнести: научное управление, бихевиористские учения и организационные теории.

Основателем и основным разработчиком идей научного управления является Фредерик Тейлор (1856 - 1915). Начав с рабочего, он прошел по всем уровням иерархии до главного инженера в сталелитейной компании. Тейлор был инженером, поэтому для него было совершенно естественным (в пределах парадигмы своего времени) смотреть на управление человеком как на управление машиной. Базируясь на механистическом понимании сущности деятельности человека труда, его места в организации, Тейлор видел решение проблемы успешности предприятия в рационализации трудовых операций. Потому для него исходным было изучение задачи. При этом он полагал, что рабочие по своей натуре - ленивые и хорошо работать могут, в лучшем случае, при экономическом стимулировании. А потому управленцы должны думать, а рабочие работать.

Основные принципы научного управления Тейлора состоят в следующем:

- разработка оптимальных приемов и методик осуществления работы на базе научного изучения затрат времени на отдельные операции;

- абсолютное следование научно обоснованным стандартам и нормам;

- подбор, обучение и расстановка рабочих на те рабочие места и задания, где они, реализуя свои способности, могут дать наибольшую отдачу;

- $\quad$ оплата по результатам труда (чем больше конкретный результат, тем больше оплата);

- использование

функциональных администраторов, осуществляющих нормоконтроль по специализированным направлениям;

- поддерживание дружеских отношений между рабочими и менеджерами, с целью реализации научного управления.

Не ослабевая внимания к научной организации труда, в $20-30$ годы прошлого столетия обратили внимание на то, что производительность труда существенно зависит от социальных условий в организации, и может быть значительно увеличена, если в рабочих группах в процессе совместной деятельности создаются особые отношения - с признаками коллективизма. Перенос центра тяжести в управлении с задач на человека породил развитие различных бихевиористских теорий менеджмента.

Так, Вальтер Дилл Скотт (1869 - 1955) выступал за то, что менеджеры должны смотреть не только сквозь призму их экономических интересов, но и - социальных, признавая их заслуги. Мари Паркер Фоллет (1868 - 1933) считала, что менеджер должен отказаться от формальных взаимодействий с рабочими, быть лидером, признанным рабочими, а не опирающимся на должностную власть. Ее трактовка менеджмента как «искусства добиваться результатов посредством действий других» во главу угла ставила гибкость и гармонию во взаимоотношениях между менеджерами и рабочими, исходя из ситуации, а не уповать на функциональные предписания.

Огромный вклад в развитие бихевиористского направления в управлении внес Абрахам Маслоу (1908 - 1970). Согласно с учением Маслоу человек имеет сложную структуру иерархически расположенных потребностей, и управление в соответствии с этим должно вестись на основе выявления потребностей рабочего и использования соответствующих методов мотивирования.

Конкретное противопоставление научного направления и бихевиористских концепций в виде их теоретического обобщения нашло отражение в теориях «Х» и «Y» Дугласа МакГригора (1906 1964). Существуют два типа управления, отражающих в своей основе два диаметрально противоположных взгляда на работников.

Для предприятий типа «Х» характерны следующие концептуальные предпосылки:

- обычный человек имеет унаследованную нелюбовь к работе;

- по причине нежелания работать человека только путем принуждения, с помощью приказов, контроля и угроз наказания можно побудить к тому, чтобы он осуществлял необходимые действия и затрачивал должные усилия для достижения предприятием своих целей;

- $\quad$ средний человек предпочитает, чтобы им управляли, старается не брать на себя ответственности, имеет относительно низкие амбиции и желает находиться в безопасной ситуации.

Для предприятий типа «Y» характерны следующие предпосылки:

- выражение физических и эмоциональных усилий на работе для человека также естественно, как и во время игры или отдыха. Внешний контроль и угроза наказания не являются единственными средствами побуждения человека к деятельности. Человек в своей деятельности руководствуется определенным набором ценностей, усвоенных в процессе воспитания, осуществляя самоконтроль и самопобуждение;

- ответственность и обязательства по отношению к целям организации зависят от вознаграждения, получаемого за результаты труда. Наиболее важным вознаграждением 


\begin{tabular}{|c|c|c|c|c|c|c|}
\hline \multirow{4}{*}{ Impact Factor: } & ISRA (India) & $=3.117$ & SIS (USA) & $=0.912$ & ICV (Poland) & $=6.630$ \\
\hline & ISI (Dubai, UAE & $=0.829$ & РИНЦ (Russia) & $=0.156$ & PIF (India) & $=1.940$ \\
\hline & GIF (Australia) & $=0.564$ & ESJI (KZ) & $=8.716$ & IBI (India) & $=4.260$ \\
\hline & JIF & $=1.500$ & SJIF (Morocco & $=5.667$ & OAJI (USA) & $=0.350$ \\
\hline
\end{tabular}

является то, которое связано с удовлетворением потребностей в самовыражении и само актуализации;

- обычный человек, воспитанный определенным образом, не только готов брать на себя ответственность, но и даже стремится к этому.

При этом Мак Григор подчеркивал, что многим людям присуща готовность использовать свой опыт, знания и воображение в решении проблем предприятия. Однако современное индустриальное общество слабо использует интеллектуальный потенциал обычного человека.

Если, заботясь об успешности деятельности предприятия, Тейлор концентрировал внимание на том, как лучше выполнять задачи, исследуя операции и функции, Мэйо и бихевиористы искали ответы на те же вопросы, обращаясь к природе отношений в коллективе, к мотивам человеческой деятельности, то Фаоль пытался подойти к решению проблемы с позиции совершенствования самой управленческой деятельности.

Анри Файоль (1841 - 1925) почти всю свою сознательную жизнь (58 лет) проработал во французской компании по переработке угля и железной руды. Он считал, опираясь на личный опыт, что при правильной организации своей работы каждый менеджер может добиться успеха.

Рассматривая предприятие как единый организм, Файоль полагал, что для любой деловой организации характерно наличие шести определенных видов деятельности, или функций:

- техническая

деятельность

(производство);

- коммерческая деятельность (закупка. Сбыт и обмен);

- финансовая деятельность (поиск и оптимальне использование капитала);

- деятельность безопасности (защита корпоративной собственности);

- эккаунтинг (деятельность по анализу, учету, статистике);

- управление (планирование, функция организации, распорядительство, координация и контроль).

Выделив управление в самостоятельный вид деятельности и наделив его пятью специфическими функциями (планирование, организация, распорядительство, координация и контроль), Файоль разработал четырнадцать принципов управления, которым он сам следовал в своей практике и от которых, как он считал, зависит успех управления:

- Разделение труда (повышает квалификацию и уровень выполнения работы).

- Власть (право отдавать команды и нести ответственность за результаты).
- Дисциплина (четкое и ясное взаимопонимание между рабочими и менеджерами, базирующееся на уважении к правилам и договоренностям, существующим на предприятии в основном - результат возможностей руководства).

- Единство

распорядительства (распоряжения только от одного руководителя и подотчетность только одному руководителю).

- Единство

руководства

(один руководитель и единый план для каждого набора действий по достижению каких-то единых целей).

- Подчинение индивидуальных интересов общим интересам (менеджер должен добиваться с помощью личного примера и жесткого, но справедливого управления того, чтобы интересы индивидов, групп и подразделений не превалировали над интересами предприятия в целом).

- Вознаграждение персонала (оплата должна отражать состояние предприятия и стимулировать людей на работу с отдачей).

- Централизация (уровень централизации и децентрализации должен зависеть от ситуации и выбираться таким образом, чтобы давать лучшие результаты).

- Цепи взаимодействия (четкое построение цепей следования команд от руководства к подчиненным).

- $\quad$ Порядок (все должны знать свое место на предприятии).

- $\quad$ Равенство (к рабочим следует подходить справедливо и по-доброму).

- Стабильность персонала (кадры должны находиться в стабильной ситуации).

- Инициатива (менеджеры должны поощрять подчиненных выдвигать идеи).

- Корпоративный дух (следует создавать дух единства и совместных действий, развивать бригадную форму работы).

Утверждая

универсальность сформулированных принципов, Файоль тем не менее подчеркивал необходимость их гибкого применения, с учетом ситуации, в которой осуществляется управление.

Несомненно, огромный вклад в развитие управленческой мысли внес немецкий юрист и социолог Макс Вебер (1864 - 1920), разработавший теорию бюрократического построения предприятия и системы управления в частности.

Вебер считал, что бюрократическая система должна обеспечить работу предприятия как машины, гарантируя скорость, точность, порядок, определенность, непрерывность

и предсказуемость. 


\begin{tabular}{|c|c|c|c|c|c|c|}
\hline \multirow{4}{*}{ Impact Factor: } & ISRA (India) & $=\mathbf{3 . 1 1 7}$ & SIS (USA) & $=0.912$ & ICV (Poland) & $=6.630$ \\
\hline & ISI (Dubai, UAE & $=0.829$ & РИНЦ (Russia & $=0.156$ & PIF (India) & $=1.940$ \\
\hline & GIF (Australia) & $=0.564$ & ESJI (KZ) & $=8.716$ & IBI (India) & $=4.260$ \\
\hline & JIF & $=1.500$ & SJIF (Morocco & $=5.667$ & OAJI (USA) & $=0.350$ \\
\hline
\end{tabular}

Основными принципами построения предприятия, обеспечивающими эти качества, по Веберу, должны быть следующие:

- разделение труда на базе функциональной специализации;

- хорошо определенная иерархическая система распределения власти;

- система правил и норм, определяющих права и обязанности работников;

- система правил и процедур поведения в конкретных ситуациях;

- отсутствие личностного начала в межличностных отношениях;

- прием на предприятие на основе компетентности и потребностей предприятия;

- продвижение по службе на основе компетентности и широких знаний предприятий, которые приходят с выслугой лет;

- стратегия к пожизненному найму;

- четкая система карьеры, обеспечивающая продвижение наверх для квалифицированных работников;

- управление административной деятельностью состоит в разработке и установлении доскональных письменных инструкций на предприятиях.

«Синтетические» учения об управлении. Для «синтетических» учений характерен взгляд на управление как на многоплановое, комплексное и изменяющееся явление, связанное множеством связей с внутренней и внешней средой предприятия. Первые успехи такого осмысления управления оформились как системный подход к предприятию. Открылась возможность глубокого проникновения в систему внутренних и внешних связей и многофакторного анализа, как объекта, так и субъекта управленческой деятельности.

Несомненно, одним из самых выдающихся теоретиков современности в области системного взгляда на управление следует считать Питера Дракера. Центром идей Дракера об управлении является систематизированное учение о менеджменте как о профессиональной деятельности и о менеджере как о профессии. Это позволило организовать изучение менеджмента в учебных заведениях и открыть подготовку менеджеров.

Одним из самых известных теоретических положений, выдвинутых Дракером, является его концепция управления по целям. Идея Дракера о том, что управление должно начинаться с выработки целей и потом переходить к формированию функций, системы взаимодействия и процесса, в корне перевернула логику управления.

Среди «синтетических» учений об управлении заметное место занимают ситуационные теории. Ситуационные теории дают рекомендации относительно того, как следует управлять в конкретных ситуациях. При этом рекомендуется пошаговый алгоритм решения проблем. Во-первых, необходимо внимательно осуществить анализ конкретной ситуации, выделив какие требования к предприятию предъявляет ситуация и что характерно для ситуации. Во-вторых, должен быть выбран соответствующий подход к осуществлению управления. В-третьих, управление должно создавать потенциал в предприятии и необходимую гибкость для того, чтобы можно было перейти к новому управленческому стилю, соответствующему ситуации. В-четвертых, управление должно произвести соответствующие изменения, позволяющие подстроиться к ситуации.

Одной из наиболее популярных системных концепций менеджмента является теория «7-S», разработанная в 80-е гг. (США). Было подмечено, что эффективная организация, как правило, формируется на безе семи взаимосвязанных составляющих, изменение каждой из которых с необходимостью требует соответствующего изменения остальных шести. Эти ключевые составляющие являются следующие:

- стратегия - планы и направления действий, определяющие распределение ресурсов, фиксирующие обстоятельства по осуществлению определенных действий во времени для достижения поставленных целей;

- структура - внутренняя композиция предприятия, отражающая взаимное положение организационных подразделений, иерархическую субординацию этих подразделений и распределение власти между ними;

- системы - процедуры и рутинные процессы, протекающие на предприятии;

- штат - ключевые группы персонала, существующие на предприятии и охарактеризованные по возрасту, полу, образованию и т.п.;

- стиль - способ, каким руководители управляют предприятием, включая и организационную культуру;

- квалификация - отличительные возможности ключевых людей на предприятии;

- разделенные ценности - смысл и содержание основных направлений деятельности, которые предприятие доводит до своих членов.

В 1981 г. американец Ульям Оучи, на основе японского опыта управления выдвинул теорию «Z», как бы дополняя и развивая идеи Мак Григора и нивелируя положения ситуационных теорий. Исходным пунктом концепции Оучи является положение о том, что человек - это основа любой предприятия и от него в первую очередь зависит успех функционирования 


\begin{tabular}{|c|c|c|c|c|c|c|}
\hline \multirow{4}{*}{ Impact Factor: } & ISRA (India) & $=3.117$ & SIS (USA) & $=0.912$ & ICV (Poland) & $=6.630$ \\
\hline & ISI (Dubai, UAE & $=0.829$ & РИНЦ (Russia & $=0.156$ & PIF (India) & $=1.940$ \\
\hline & GIF (Australia) & $=0.564$ & ESJI (KZ) & $=8.716$ & IBI (India) & $=4.260$ \\
\hline & JIF & $=1.500$ & SJIF (Morocco & $=5.667$ & OAJI (USA) & $=0.350$ \\
\hline
\end{tabular}

предприятия. Исходя из этого, Оучи и сформулировал основные положения и правила эффективного управления людьми.

Идеи теории «Z» в сжатом виде сводятся к следующему:

- долгосрочный наем кадров;

- $\quad$ групповое принятие решений;

- индивидуальная ответственность;

- медленная дифференцированная оценка кадров и их умеренное пошаговое продвижение по службе;

- косвенный, неформальный контроль четкими и формализованными методами;

- неспециализированная карьера;

- всесторонняя забота о работниках.

Этот краткий обзор учений об управлении показывает, что практика постоянно высвечивает все новые и новые проблемные грани управления совместной деятельностью, возникающие при поступательном ее развитии. Наука, в свою очередь, своевременно и эффективно отвечает на запросы практики, выдвигая при этом своего рода ориентиры, весьма полезные для практиков, так направляемые четырехступенчатую модель достижения успеха, а именно:

1. Решите, чего вы хотите (сформулируйте и поставьте перед собою цель).

2. Сделайте что-нибудь.

3. Посмотрите, что получится.

4. Если понадобится - меняйте подход, пока не добьетесь желаемого.

Ставить верные цели - это значит - уметь «правильно сформулировать результат».

\section{Принциипы правильной формулировки} результата (РДТСС)

Реалистичность Достижимость Точность Своевременность Соизмеримость

Основные принципы формирования и выбора своих целей:

1. Выбирайте такие цели, которые заслуживают их достижения.

2. Выбирайте такую цель, которой сможете достичь своими силами.

3. Формулируйте свою цель в утвердительных терминах.

4. Выражайте свою цель точно, в сенсорных категориях.

5. Соотносите свою цель с контекстом (ситуацией).

6. Трезво оценивайте последствия достижения своей цели.

Подсознание играет важную роль во всем, что мы делаем. Деловые и организационные методы достижения целей (формализованные) обычно опускают этот фактор. То же относится и к индивидуальным целям, выбранным логическим, систематическим путем, «левым полушарием».

Думать в утвердительной форме - это принцип правильной формулировки результата.

Многие обычно сосредотачиваются на попытках избежать нежелательного вместо того, чтобы думать о желаемом и добиваться желаемого. У них формируется «агрессивнооборонительный», «отрицающий» характер вместо «утверждающего». «Отрицающий человек» переживает, в конце концов, тот сценарий, которого хотел бы избежать, ибо именно он закрепляется стратегически и реализуется. Можно назвать такую систему «избегания» осмотрительностью, реализмом, благоразумием и так далее. Наиболее действенно она проявляется при достижении внутренних целей, но когда дело касается осознаваемых целей «...?..», она нередко приводит к непостижимым на первый взгляд промахам. Потому первый принцип правильно сформулированного результата гласит: «Выражаю свою цель в утвердительных терминах».

Установки нейро-лингвистического программирования (НЛП):

Меняя свои мысли, вы начинаете вести себя подругому и добиваетесь иных результатов.

Карта - не территория.

То, что больше всего занимает наши мысли (сознательно или неосознанно), обычно отражается в поведении и становится явью.

То, что вы видите, слышите и чувствуете в воображении, дает представление о реальных событиях в будущем.

Управляйте тем, чем можно управлять, и не тревожьтесь об остальном.

Все вокруг нас, что было создано человеком, первоначально возникло у кого-то в мыслях.

Достигнуть цели означает достигнуть своей цели.

Оценивайте общую совокупность перемен, связанных с достижением намеченного результата.

Человек - не его поведение. Люди сами творят свои переживания.

Смысл общения - в реакции собеседника.

Переживания имеют свою структуру.

Мы видим не глазами, а мозгом.

За каждым поступком - благие побуждения.

Сознательно меняя субмодальности, вы меняете свои переживания.

Разум и тело - взаимодополняющие одной системы.

Каждый выбирает лучшее из того, что ему доступно

Каждый действует по-своему безупречно. 


\begin{tabular}{|c|c|c|c|c|c|c|}
\hline \multirow{4}{*}{ Impact Factor: } & ISRA (India) & $=3.117$ & SIS (USA) & $=0.912$ & ICV (Poland) & $=6.630$ \\
\hline & ISI (Dubai, UAE & $=0.829$ & РИНЦ (Russia) & $=0.156$ & PIF (India) & $=1.940$ \\
\hline & GIF (Australia) & $=0.564$ & ESJI (KZ) & $=8.716$ & IBI (India) & $=4.260$ \\
\hline & JIF & $=1.500$ & SJIF (Morocco & $=5.667$ & OAJI (USA) & $=0.350$ \\
\hline
\end{tabular}

Не бывает неудач, есть только опыт.

Сопротивление - реакция на форсируемое общение и вероятный признак неудачного присоединения.

Обучение - это жизнь. Мы не можем не учиться.

Нет проблемы, у которой бы не было решения.

Если что-то по силам одному, оно по силам каждому.

Выбор лучше его отсутствия.

Изменения могут быть моментальными.

Системой управляет тот, кто проявляет наибольшую гибкость.

У каждого есть все необходимое для осуществления перемен и достижения успеха.

Никто не может не реагировать.

Кем бы вы себя ни считали, на самом деле вы нечто большее.

Я несу ответственность за свои мысли - a значит, и за достигаемые результаты.

Содержание любого события зависит от рамки, в которой мы его воспринимаем.

\section{Принцины сбалансированного самообновления}

Возможно, мы начали понимать, что если мы хотим что-либо изменить, то начинать изменение надо с себя. И для того, чтобы изменить себя эффективно, мы, прежде всего, должны поменять свое восприятие.

Принципы НЛП предполагают учет всех четырех измерений. Это означает, что мы должны регулярно и последовательно развивать их самым разумным и сбалансированным образом. Расходование времени на самообновление требует от нас инициативы.

Эффективные навыки - хорошо усвоенные принципь и модели поведения (рис. 3.2). Чтобы что-то в своей жизни превратить в навык, необходимы три компонента: Знание, Умение, Желание (см. рис. 3.2).

Знание - это теоретическая парадигма, определяющая что делать $u$ зачем. Умение определяет как делать. А желание - это мотивация - хочу делать.

Если однажды мы поверим, что отныне наше поведение зависит от наших решений, а не от окружающих условий, то самый первый навык, необходимый при начавшемся саморазвитии личности - это проактивность. Под проактивностью надо понимать, осмыслив ее как факт, что, инициируя происходящее, подчиняя чувства нашим ценностям, мы несем ответственность за свои действия (и, прежде всего, перед собой). Поведение проактивного человека есть продукт его собственного выбора, он не ищет «виноватых» за свои поступки и за их результаты (рис. 3). В этом случае он себя спрашивает, и в себе ищет ответ. Стивен Р. Кови полагает, что для достижения личной победы (победы над собой) человеку как минимум нужно еще два навыка (рис..4) (кроме - «Будь проактивным» (1): это - «Начинай, представляя конечную цель» (2), и «Сначала делай то, что необходимо делать сначала» (3). Если в значении цели в нашей деятельности мы уже достаточно четко определились, то с третьим навыком надо еще разобраться. В данном случае имеется в виду необходимость управлять своим временем, четко представляя степень важности и срочности тех дел, которые намечаем к исполнению.

Вполне очевидно, что для овладения навыком «Сначала делай то, что необходимо делать сначала», не срочные, но весьма важные дела по поддержанию своего ресурса, поэтому будем стараться делать их в первую очередь, и именно в этом деле как раз и будем нарабатывать первый и второй навыки.

По мере овладения первыми тремя навыками мы все больше будем приобретать независимость от внешних факторов и все больше открывать возможности закрепления личной победы, пробуя по-новому взаимодействовать с окружающим нас миром себе подобных, осознавая объективную взаимозависимость. Для этого нам понадобятся еще три навыка: «Думай в духе выиграл/выиграл» (4), «Сначала стремись понять, а потом быть понятым» (5), Достигайте синергии» (6). Сотрудничество и доверие - и результат и условие для закрепления этих важных в общении и коллективной деятельности навыков.

Седьмой навык (7) Стивен Р. Кови назвал «Затачивай пилу». Он не двусмысленно полагал (рис.5), что мы можем рассчитывать на успех, на эффективность только тогда, когда будем делать постоянные усилия в деле формирования всех названных навыков, работая над всесторонним саморазвитием.

В заключение надо признать, что, работая над своим обновлением в одиночку, сомнительно добиться успеха, даже имея все три составляющие для формирования необходимых навыков. Человек - существо социальное. Реально воспитание осуществляется только через поступок. В воспитании участвуют трое: - кроме воспитуемого, еще должны быть 


\begin{tabular}{|c|c|c|c|c|c|c|}
\hline \multirow{4}{*}{ Impact Factor: } & ISRA (India) & $=3.117$ & SIS (USA) & $=0.912$ & ICV (Poland) & $=6.630$ \\
\hline & ISI (Dubai, UAE & $=0.829$ & РИНЦ (Russia & $=0.156$ & PIF (India) & $=1.940$ \\
\hline & GIF (Australia) & $=0.564$ & ESJI (KZ) & $=8.716$ & IBI (India) & $=4.260$ \\
\hline & JIF & $=1.500$ & SJIF (Morocco & $=5.667$ & OAJI (USA) & $=0.350$ \\
\hline
\end{tabular}

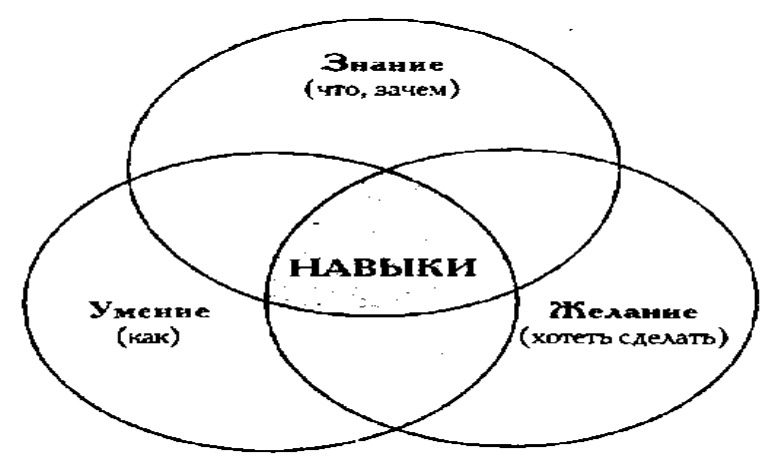

Рис. .2. Характеристика эффективных навыков в поведении человека

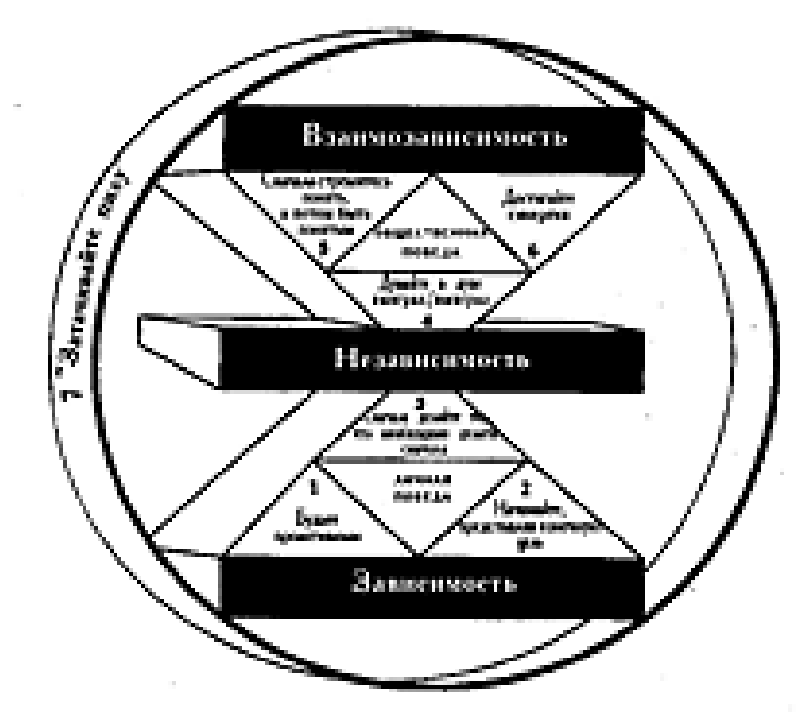

Рис 3 - Матрица управления временем

- воспитатель (делай как я) и ценитель (того чему учат и как получается). При самовоспитании - где взять еще двух недостающих? Выход только один - найти образ, который бы был учителем, найти образ, который был бы ценителем. Мы не оговорились, а вы не ошиблись - именно ОБРАЗ или ОБРАЗЫ. Для этого могут подойти литературные герои, друзья, подруги, папы, мамы, бабушки, дедушки ... при вашем богатом воображении.

Несмотря на принципиальные отличия вышерассмотренных концепций, они, тем не менее, имеют нечто общее в своей основе, что отражает определенную общность в мотивации человека к действиям.

Названные концепции позволяют сделать вывод о том, что отсутствует какое-либо канонизированное учение, объясняющее то, что лежит в основе мотивации человека и чем определяется мотивация. Каждая из изложенных теорий имеет определенное принципиальное отличие. Так, например, в концепции Маслоу потребности расположены иерархически, и восхождение по ним идет снизу вверх. В теории Альдерфера также имеется определенная иерархия. Однако эта теория в качестве одного из важнейших положений имеет утверждение о том, что движение по иерархии может осуществляться как снизу вверх, так и обратно сверху вниз в том случае если не удовлетворяется потребность верхнего уровня. МакКлелланд ввел по отношению к рассматриваемым им потребностям идею их приобретения: и развития под влиянием обучения и жизненного опыта. При этом он принимает во внимание взаимоотношение отдельных групп потребностей, отойдя от рассмотрения изолированного влияния отдельных групп потребностей на поведение человека. В теории Герцберга потребности делятся на две большие группы: мотивирующие и «здоровья». Тем самым указывается на то, что не все потребности постоянно оказывают мотивирующее влияние на человека, а только те из них, которые приводят к развитию состояния удовлетворенности. 


\begin{tabular}{|c|c|c|c|c|c|c|}
\hline \multirow{4}{*}{ Impact Factor: } & ISRA (India) & $=3.117$ & SIS (USA) & $=0.912$ & ICV (Poland) & $=6.630$ \\
\hline & ISI (Dubai, UAE & $=0.829$ & РИНЦ (Russia) & $=0.156$ & PIF (India) & $=1.940$ \\
\hline & GIF (Australia) & $=0.564$ & ESJI (KZ) & $=8.716$ & IBI (India) & $=4.260$ \\
\hline & JIF & $=1.500$ & SJIF (Morocco) & $=5.667$ & OAJI (USA) & $=0.350$ \\
\hline
\end{tabular}

Как видно, каждая из теорий имеет что-то особенное, отличительное, что дало ей возможность получить широкое признание теоретиков и практиков и внести существенный вклад в разработку знаний о мотивации. Однако при этом, несмотря на принципиальные различия, все четыре вышеописанные теории имеют нечто общее, позволяющее установить определенные параллели между ними. Характерной особенностью всех четырех теорий является то, что они изучают потребности и дают классификацию потребностей, позволяющую делать некие выводы о механизме мотивации человека. Сравнивая классификации всех четырех теорий, можно отметить, что выделенные в различных теориях группы потребностей достаточно определенно соответствуют друг другу. Так, например, потребность достижения в теории МакКлелланда созвучна потребности самовыражения в пирамиде Маслоу, потребности роста в теории Альдерфера группе потребностей, входящих в набор мотивирующих факторов, теории Герцберга. Такое же соответствие можно установить и для других групп потребностей.

В табл.3 дано некое условное соответствие групп потребностей мотивации человека к действию, выделяемых в данных четырех концепциях.

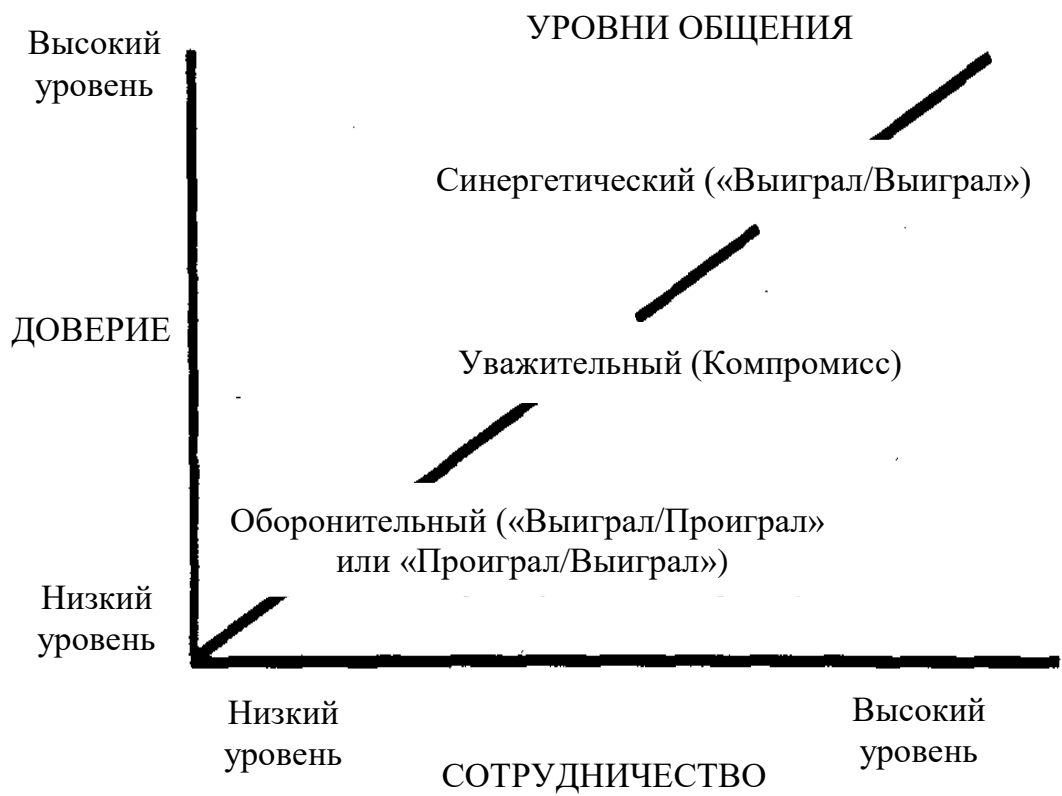

Рис. 3.5. Эффективность общения

Таблица 3. Характеристики мотивации человека и действий, сформулированные в своих концепциях Маслоу, Альдерфера, МакКлелланда и Герцберга.

\begin{tabular}{|c|c|c|c|c|c|}
\hline Теории & \multicolumn{5}{|c|}{ Группы потребностей } \\
\hline $\begin{array}{c}\text { Теория } \\
\text { Маслоу }\end{array}$ & $\begin{array}{c}\text { Потребность } \\
\text { самовыражения }\end{array}$ & $\begin{array}{c}\text { Потребность } \\
\text { признания } \\
\text { и самоутверждения }\end{array}$ & $\begin{array}{c}\text { Потребность } \\
\text { принадлежности } \\
\text { и причастности }\end{array}$ & $\begin{array}{c}\text { Потребность } \\
\text { безопасности }\end{array}$ & $\begin{array}{c}\text { Физиологические } \\
\text { потребности }\end{array}$ \\
\hline $\begin{array}{c}\text { Теория } \\
\text { Альдерфера }\end{array}$ & Потребность роста & Потребность связи & Потребность существования \\
\hline $\begin{array}{c}\text { Теория } \\
\text { МакКлелланда }\end{array}$ & \multicolumn{2}{|l|}{ Потребность достижения } & Потребность властвования & Потребность соучастия \\
\hline $\begin{array}{c}\text { Теория } \\
\text { Герцберга }\end{array}$ & \multicolumn{3}{|c|}{ Фотивирующие факторы } & \multicolumn{3}{|c|}{ Факторы здоровья } \\
\hline
\end{tabular}

\section{Заключение}

Выбор предприятий машиностроения в качестве объекта для оценки эффективности социально - психологического фактора при внедрении СМК обусловлен тем, что эти предприятия характеризуются наличием высококвалифицированных рабочих и специалистов. Таким образом, Политика и Цели в 


\begin{tabular}{|c|c|c|c|c|c|c|}
\hline \multirow{4}{*}{ Impact Factor: } & ISRA (India) & $=3.117$ & SIS (USA) & $=0.912$ & ICV (Poland) & $=6.630$ \\
\hline & ISI (Dubai, UAE & $=0.829$ & РИНЦ (Russia) & $=0.156$ & PIF (India) & $=1.940$ \\
\hline & GIF (Australia) & $=0.564$ & ESJI (KZ) & $=8.716$ & IBI (India) & $=4.260$ \\
\hline & JIF & $=1.500$ & SJIF (Morocco & $=5.667$ & OAJI (USA) & $=0.350$ \\
\hline
\end{tabular}

рамках СМК будут реализовываться значительно эффективнее и с меньшими затратами за счет трех главных аспектов: вовлечение работников, процессный подход и системный подход. Кроме того, персонал предприятий машиностроения эффективнее способен реализовать цели и задачи СМК еще и потому, что эффективнее обеспечивается контрольная деятельность по выполнению следующих условий: убеждение, исполнение делегированных полномочий, создание условий для повышения производительного труда и эффективного использования деловых качеств каждого члена коллектива предприятия.

Необходимость совершенствования системы менеджмента качества на предприятиях машиностроения обусловлено следующими важными причинами. Во-первых, это повышение доверия потенциальных потребителей к продукции, которую выпускает данное предприятие. Во-вторых, это возможность значительно укрепить свое положение на уже существующих рынках, а также значительно расширить сферы влияния путем выхода на новые отечественные и зарубежные рынки. И в-третьих - это значительное повышение производительности труда любого промышленного предприятия, на котором предполагается внедрение СМК, с использованием партисипативного управления.

В настоящее время на предприятиях большое значение уделяют мотивации сотрудников, так как в зависимости от того, насколько сотрудник мотивирован, будут видны и результаты его деятельности. Основной задачей менеджеров становится полное задействование в работе всего потенциала сотрудников. Причем менеджеры понимают, что материальное стимулирование не повышает лояльность и приверженность предприятия, а партисипативное управление решает эту проблему.

Суть такого управления состоит в том, что при нем сотрудники предприятия включаются в процесс управления, участвуют в деятельности предприятия, принимают решения по ряду вопросов. Причем, если сотрудники предприятия имеют право голоса, принимают участие в деятельности предприятия, получая за это вознаграждение, тогда они будут работать более качественно и производительно. Сотрудники, с мнением которого считаются, идеи которого внедряются, будут лучше относиться к месту своей работы и будут работать с полной отдачей.

При партисипативном управлении сотрудники могут обговаривать с руководителем цели и задачи, которые ему будет необходимо выполнить. Сотрудники предприятия могут сформировать рабочие группы из тех сотрудников, с которыми им было бы приятно и комфортно работать. Помимо этого, сотрудники предприятия могут выдвигать свои идеи и предложения по поводу усовершенствования работы предприятия в целом. Причём, за выдвижение идей должно быть предусмотрено и вознаграждение.

Партисипативное управление имеет ряд преимуществ. Участие в управлении сотрудников приводит к повышению качества принимаемых решений, поскольку работники могут обладать той информацией, которая не известна руководителю. При таком управлении сотрудники могут проявить в полной мере себя, показать свои знания и умения, а также почувствовать свою значимость на предприятии, таким образом повышая мотивацию. В основе мотивации обычно присутствуют не только личные достижения сотрудника, но и общий результат работы предприятия. Объединение сотрудников по рабочим группам наилучшим образом может отразиться на корпоративном духе предприятия.

Тем не менее, партисипативный подход помимо преимуществ имеет и свои недостатки. Не все люди в силу своего характера готовы участвовать в управлении предприятием и выдвигать идеи и предложения, неся за них ответственность. Многим сотрудникам гораздо проще выполнять работу по указанию руководителя. Привлечение работников к управлению на предприятии может не лучшим образом отразиться на менеджерах, так как они могут потерять свое влияние на сотрудников. Много времени также будет уходить на обсуждение проблем, при этом однозначного решения может быть и не принято, а времени потрачено. Многие идеи и предложения сотрудников предприятия могут быть нерациональными и неуместными в силу недостаточности знаний. Поэтому, руководителям предприятия необходимо информировать сотрудников о положении дел на предприятии, обучать персонал с целью углубления знаний и выдвижения более эффективных и актуальных предложений. Отсутствие признания идеи работника может вызвать неоднозначную реакцию у сотрудника, выдвигающего свои инновационные предложения, тем самым демотивируя его. Поэтому, руководителям предприятия необходимо объяснять, почему данная идея не подходит в той или иной ситуации.

Рассмотрев все плюсы и минусы партисипативного управления, можно сделать вывод, что такое управление не является спасательным средством для улучшения дел на предприятии, но оно позволяет увидеть проблемы предприятия изнутри и попытаться решить их не усилиями одного человека, а 


\begin{tabular}{|c|c|c|c|c|c|c|}
\hline \multirow{4}{*}{ Impact Factor: } & ISRA (India) & $=3.117$ & SIS (USA) & $=0.912$ & ICV (Poland) & $=6.630$ \\
\hline & ISI (Dubai, UAE & $=0.829$ & РИНЦ (Russia & $=0.156$ & PIF (India) & $=1.940$ \\
\hline & GIF (Australia) & $=0.564$ & ESJI (KZ) & $=8.716$ & IBI (India) & $=4.260$ \\
\hline & JIF & $=1.500$ & SJIF (Morocco & $=5.667$ & OAJI (USA) & $=0.350$ \\
\hline
\end{tabular}

группой лиц, где каждый сможет проявить себя на благо предприятия.

Еще одним очень важным фактором, не позволяющим принять партиситипативный метод управления персонала на российские предприятия, можно принять влияние национальной культуры России. От этого влияния зависит выбор стратегии управлением кадровыми ресурсами в практической деятельности предприятия.

Для того чтобы наиболее успешно внедрить парситипативное управление кадрами и подготовить сотрудников к изменению подхода работы в коллективе, прежде всего необходимо установить меры по поощрению индивидуальности в каждом работнике предприятия и устранить устоявшуюся недоступность руководителя для низшего звена. Важно создать качественную и действующую систему мотивации и постоянное повышение квалификации, чтобы персонал стал источником конкурентоспособности предприятия, соответствовал современным требованиям к управлению человеческими ресурсами.

Руководство по качеству направлено на применение «процессного подхода» при разработке, внедрении и улучшении результативности системы менеджмента качества c целью повышения удовлетворенности потребителей путем выполнения их требований.

Преимущество процессного подхода состоит в непрерывности управления, которое он обеспечивает на стыке отдельных процессов в рамках системы, а также при их комбинации и взаимодействии.

Основными процессами системы менеджмента качества являются:

- $\quad$ проектирование и разработка продукции;

- $\quad$ составление плана производства;

- производство;

- контроль и проведение испытаний продукции;

- упаковка и хранение продукции;

- $\quad$ продажа;

- закупки;

- обеспечение ресурсами;

- проведение маркетинговых исследований.

Виды деятельности по измерению и мониторингу для обеспечения и верификации соответствия продукции определены в комплексной документации, производственных планах и сменных заданиях, технологических процессах, процедурах по измерению, анализу и улучшению.

Деятельность по мониторингу, измерениям, анализу и улучшению включает в себя:

- исследование потребителей;
- внутренний аудит;

- $\quad$ мониторинг и измерение процессов;

- $\quad$ мониторинг и измерение продукции;

- управление несоответствующей продукцией;

- непрерывное улучшение, в том числе корректирующие и предупреждающие действия;

- определение мест применения инженерных и статистических методов.

Проявившийся брак, полученный при реализации поршней, или в процессе использования продукции свидетельствует не только о качестве продукции, но и о неудовлетворительной работе предприятия.

В этой связи коллектив рабочих и служащих совместно с руководством АО «Шахтинский завод Гидропривод» приняли коллективное решение по разработке и внедрению СМК, а также по повышению её результативности и эффективности. Эти цели и задачи реализованы в виде политики и целей предприятия в области качества в 2017 году, для чего они и были сформулированы.

В современных условиях обострения конкуренции, превращения её в глобальную основу выживания и успеха предприятия, основой устойчивого положения предприятия на рынке является своевременное предложение продукции, соответствующей мировому уровню качества. При этом, конкурентоспособность любого предприятия, независимо от размеров, формы собственности и других особенностей, зависит в первую очередь от качества продукции и соизмеримости её цены с предлагаемым качеством, т.е. от того, в какой степени продукция предприятия удовлетворяет запросам потребителя.

Качество формируется в процессе производства продукции, следовательно, главным фактором обеспечения качества и одним из решающих элементов обеспечения конкурентоспособности предприятия является действующая на предприятия система менеджмента качества.

Эти обстоятельства приводят к закономерному росту роли системы менеджмента качества предприятия как универсального инструмента повышения конкурентоспособности предприятия, позволяющего достичь цели снижения себестоимости производимой продукции при абсолютном удовлетворении требований потребителя.

Наиболее распространённой в мире основой создания систем менеджмента качества предприятий является международные стандарты ИСО серии 9000. Создание системы менеджмента качества на основе этих стандартов позволяет перейти от управления качеством продукции к менеджменту качества всего предприятия [3]. 


\begin{tabular}{|c|c|c|c|c|c|c|}
\hline \multirow{4}{*}{ Impact Factor: } & ISRA (India) & $=\mathbf{3 . 1 1 7}$ & SIS (USA) & $=0.912$ & ICV (Poland) & $=6.630$ \\
\hline & ISI (Dubai, UAE & $=0.829$ & РИНЦ (Russia & $=0.156$ & PIF (India) & $=1.940$ \\
\hline & GIF (Australia) & $=0.564$ & ESJI (KZ) & $=8.716$ & IBI (India) & $=4.260$ \\
\hline & JIF & $=1.500$ & SJIF (Morocco & $=5.667$ & OAJI (USA) & $=0.350$ \\
\hline
\end{tabular}

В рамках системы менеджмента качества реализуется учёт взаимосвязи между качеством продукции и результатами экономической деятельности предприятия через учёт затрат на обеспечение качества и сопоставление их с потерями, связанными с выпуском некачественной продукции.

Кризисное состояние отечественной экономики обуславливает исключительную актуальность проблемы создания систем менеджмента качества на российских предприятиях с целью обеспечения их конкурентоспособности. Для большинства предприятий нашей страны характерна ситуация, когда неконкурентоспособность продукции по качеству усугубляется неконкурентоспособностью по цене из-за чрезмерной затратности производства. Поэтому, одним из обязательных условий выведения российской экономики из кризисного состояния является внедрение эффективных систем менеджмента качества, способных обеспечить конкурентоспособность выпускаемых изделий по цене и качеству.

Таким образом, для повышения конкурентоспособности предприятий, проблема создания систем менеджмента качества должна решаться как на уровне отдельных предприятий, так и на государственном уровне. В числе мер, призванных стимулировать предприятия на внедрение систем менеджмента качества, является их награждение с 1996 года ежегодной Премии Правительства Российской Федерации в области качества, а также и принятое в 1998 году постановление Правительства «О некоторых мерах, направленных на совершенствование систем обеспечения качества продукции и услуг».

Однако задача создания эффективно функционирующей системы менеджмента качества должна решаться, прежде всего, на уровне конкретного предприятия с учетом его особенностей, определяемых сферой деятельности, текущим финансовым состоянием, существующим уровнем реализации системности в работе по обеспечению качества и т.д.

В настоящее время резко увеличилось количество предприятий по внедрению системы менеджмента качества на основе стандартов ИСО серии 9000, чему способствуют обстоятельства, основными из которых являются:

1) организация работ по внедрению систем качества - важный элемент нескольких федеральных программ;

2) при создании совместных предприятий зарубежные фирмы и компании зачастую ставят обязательное условие: подготовка и функционирование системы менеджмента качества в соответствии со стандартами ИСО серии 9000;

3) предприятия самых разных отраслей, стремящиеся к экспорту продукции, сталкиваются с проблемой внедрения стандартов ИСО и сертификации систем менеджмента качества на соответствие этим стандартам в ходе контрактных переговоров, а также в ряде стран возникает сложность при реализации продукции без подтверждения стабильности качества при её выпуске;

4) создание более благоприятных условий страхования, получения кредита, инвестиций, участия в тендерах, конкурсах и прочих мероприятиях, которые могут закончиться контрактом;

5) повышается исполнительская дисциплина на предприятии, улучшается мотивация сотрудников, снижаются потери, вызванные дефектами и несоответствиями:

6) предприятие становится более «прозрачным» для руководства, в связи с этим повышается качество управленческих решений.

Предприятия машиностроения активно включились в работу по разработке, внедрению и сертификации систем менеджмента качества на соответствие международным стандартам ИСО серии 9000. Для этой отрасли характерны проблемы, существующие в настоящее время во всех отраслях экономики страны. В связи со значительным спадом производства снизилось использование их производственных мощностей.

Рынок машиностроения является не монополизированным, но высококонцентрированным. Высока доля поставок машиностроительной продукции и в страны дальнего зарубежья. Поэтому, для предприятий отрасли задача внедрения и сертификации систем менеджмента качества на соответствие международным стандартам ИСО серии 9000 очень актуальна.

Ряд проблем, с которыми сталкивается предприятие на пути создания и внедрения системы менеджмента качества, а именно:

1) у специалистов наших предприятий отсутствует реальный опыт работы в условиях рыночных отношений. Во время сертификации систем качества недостаток такого опыта наблюдается во множествах форм, а именно: в неумении наладить эффективную обратную связь с потребителями; в недостаточности навыков при оценке и выборе поставщиков; в нечетком распределении ответственности между руководителями различных уровней; в дублировании некоторых процессов и т.д.;

2) принимая управленческие решения о проведении мероприятий по обеспечению качества, руководители предприятий преследуют цель не создания эффективно функционирующей системы качества, которая реально будет гарантировать качество продукции в соответствии с запросами и ожиданиями потребителей, а именно получение свидетельства, сертификата. Внешний рынок для 


\begin{tabular}{|c|c|c|c|c|c|c|}
\hline \multirow{4}{*}{ Impact Factor: } & ISRA (India) & $=3.117$ & SIS (USA) & $=0.912$ & ICV (Poland) & $=6.630$ \\
\hline & ISI (Dubai, UAE & $=0.829$ & РИНЦ (Russia & $=0.156$ & PIF (India) & $=1.940$ \\
\hline & GIF (Australia) & $=0.564$ & ESJI (KZ) & $=8.716$ & IBI (India) & $=4.260$ \\
\hline & JIF & $=1.500$ & SJIF (Morocco & $=5.667$ & OAJI (USA) & $=0.350$ \\
\hline
\end{tabular}

отечественных предприятий, не имеющих систему качества на базе стандартов ИСО серии 9000, практически закрыт. Поэтому администрацию предприятий в первую очередь интересуют сроки получения международного сертификата качества. А вопросы, касающиеся объёмов трудовых, материально-технических и финансовых ресурсов, необходимых для внедрения и сертификации системы качества и, самое главное, для обеспечения ее экономически эффективной работы, отходят на второй план;

3) назначение специалистов для разработки и внедрения систем управления качеством по международной системе менеджмента качества со стороны руководства предприятия нередко осуществляется без должного отбора кандидатур и понимания тех критериев, которым эти кандидатуры должны удовлетворять.

Несмотря на множество причин, делающих работу по внедрению международной системы менеджмента качества, основанной на международных стандартах ИСО серии 9000, на отечественных предприятиях отнюдь не лёгкой, многие предприятия всё же совершенно осознанно встали на этот путь. В процессе целенаправленной работы над совершенствованием своих систем управления качеством они добились ощутимых перемен к лучшему, укрепили свои позиции среди конкурентов и теперь ставят перед собой более сложные цели. Повышение конкурентоспособности предприятия на основе внедрения и совершенствования системы менеджмента качества представляет собой проблему, для решения которой требуется комплексный подход, охватывающий не только процесс производства продукции, но и её реализацию и обслуживание после продажи.

В сентябре 2015 года вступил в силу международный стандарт ISO 9001:2015. Российская версия стандарта ГОСТ Р ИСО 90012015 «Системы менеджмента качества. Требования» вступила в силу с 01 ноября 2015 года.

В новой версии стандарта ГОСТ Р ИСО 9001-2015 относительно предыдущей внесены значительные изменения, в частности изменилась структура стандарта. В новой версии стандарта вместо 9 теперь представлено 10 разделов.

В обновленную версию ГОСТ Р ИСО 90012015 [4] входят следующие разделы:

0 . Введение.

В данном разделе стандарта ГОСТ Р ИСО 9001-2015 даны общие положения о системе менеджмента качества, принципах менеджмента качества и процессном подходе.

1. Область применения.

Раздел устанавливает область применения стандарта ГОСТ Р ИСО 9001-2015. Как и в прошлой версии стандарта ГОСТ ISO 9001-2011 раздел устанавливает единые требования к системам менеджмента качества предприятий, вне зависимости от размера и сфер деятельности. Стандарт ГОСТ Р ИСО 9001-2015 может применяться:

когда предприяте хочет продемонстрировать способность производить продукцию или предоставлять услуги, соответствующие требованиям Заказчиков;

- для целей повышения удовлетворенности потребителей.

2. Нормативные ссылки.

В данном разделе стандарта ГОСТ Р ИСО 9001-2015 даны ссылки на взаимосвязанные стандарты.

3. Термины и определения.

Термины и определения, используемые в ГОСТ Р ИСО 9001-2015, приведены в новой версии стандарта ГОСТ Р ИСО 9000-2015 .

4. Окружение организации.

В данном разделе ГОСТ Р ИСО 9001-2015 установлены требования к:

- выявлению внутренних и внешних условий деятельности организации, влияющих на систему менеджмента качества и результаты деятельности организации;

-выявлению заинтересованных сторон, оказывающих влияние на СМК и определению требований заинтересованных сторон, осуществлению мониторинга данных требований;

- определению области применения системы менеджмента качества, которая должна быть зафиксирована документально;

- к определению и управлению процессами СМК. Также для каждого процесса СМК должны быть выявлены возможности и риски.

5. Лидерство.

В данном разделе ГОСТ Р ИСО 9001-2015 установлены требования к:

- высшему руководству, которое должно взять на себя лидирующую роль по внедрению и управлению СМК.

- политике в области качества;

- высшему руководству, которое должно определить ответственность, полномочия и распределить роли на предприятии для функционирования СМК и реализации требований потребителей.

6. Планирование.

В данном разделе ГОСТ Р ИСО 90012015 установлены требования к:

- определению рисков и возможностей, способных повлиять на СМК и достижению предприятием запланированных результатов. Устанавливаются требования по разработке плана реагирования на риски и возможности;

- определению целей в области качества и планированию достижений целей в области качества; 


\begin{tabular}{|c|c|c|c|c|c|c|}
\hline \multirow{4}{*}{ Impact Factor: } & ISRA (India) & $=3.117$ & SIS (USA) & $=0.912$ & ICV (Poland) & $=6.630$ \\
\hline & ISI (Dubai, UAE & $=0.829$ & РИНЦ (Russia & $=0.156$ & PIF (India) & $=1.940$ \\
\hline & GIF (Australia) & $=0.564$ & ESJI (KZ) & $=8.716$ & IBI (India) & $=4.260$ \\
\hline & JIF & $=1.500$ & SJIF (Morocco & $=5.667$ & OAJI (USA) & $=0.350$ \\
\hline
\end{tabular}

- планированию изменений СМК.

7. Обеспечение

В данном разделе ГОСТ Р ИСО 9001-2015 установлены требования к:

- управлению ресурсами, инфраструктурой, персоналом, знаниями, производственной средой, а также средствами для проведения мониторинга и измерений;

- требования к компетентности персонала; $\mathrm{CMK}$

- осведомленности персонала по вопросам

- определению внешних и внутренних взаимодействий, влияющих на СМК организации; документированию

(создание, актуализация, управление документированной информацией).

8. Процессы.

В данном разделе ГОСТ Р ИСО 9001-2015 установлены требования к: CMK;

- планированию и управлению процессами

- определению требований к продукции и услугам;

- разработке и проектированию продукции и услуг;

- управлению внешним обеспечением продукции и услуг;

- сохранению продукции и услуг;

- выпуску продукции и услуг;

- управлению несоответствующими продукцией, услугами, процессами.

9. Проведение оценки.

В данном разделе ГОСТ Р ИСО 9001-2015 установлены требования к:

-проведению мониторинга, измерений, анализу и оценке СМК и деятельности предприятия. Также устанавливает требования к измерению удовлетворенности потребителей;

- к проведению внутренних аудитов СМК;

- проведению высшим руководством анализа

СМК предприятия.

10. Улучшения

В данном разделе ГОСТ Р ИСО 90012015 установлены требования к: проведению улучшений в продукции, услугах и процессах, а также СМК предприятия.

действиям при обнаружении несоответствий, проведению корректирующих действий;

- непрерывному совершенствованию СМК и результатов деятельности предприятия.

Новая структура стандарта нашла отражение и в схематичном представлении процессного подхода. Схема процессного подхода отражает взаимосвязь всех разделов стандарта, как это представлено на рисунке 1.

Ключевыми изменениями в новой версии стандарта являются требования по оценке рисков, a также подход, основанный на управлении рисками при проектировании и разработке системы менеджмента.

Международным форумом по аккредитации (IAF) одобрен трехлетний переходный период с обязательного ISO 9001:2008 (ГОСТ Р ИСО 90012011) на ISO 9001:2015 (ГОСТ Р ИСО 9001-2015). В это период будут действовать оба стандарта и сертификаты соответствия им, выданные организациям органами по сертификации. Сертификаты, выданные на соответствие ISO 9001:2008, прекратят свое действие только в сентябре 2018 года. 


\begin{tabular}{|c|c|c|c|c|c|c|}
\hline \multirow{4}{*}{ Impact Factor: } & ISRA (India) & $=3.117$ & SIS (USA) & $=0.912$ & ICV (Poland) & $=6.630$ \\
\hline & ISI (Dubai, UAE & $=0.829$ & РИНЦ (Russia & $=0.156$ & PIF (India) & $=1.940$ \\
\hline & GIF (Australia) & $=0.564$ & ESJI (KZ) & $=8.716$ & IBI (India) & $=4.260$ \\
\hline & JIF & $=1.500$ & SJIF (Morocco & $=5.667$ & OAJI (USA) & $=0.350$ \\
\hline
\end{tabular}

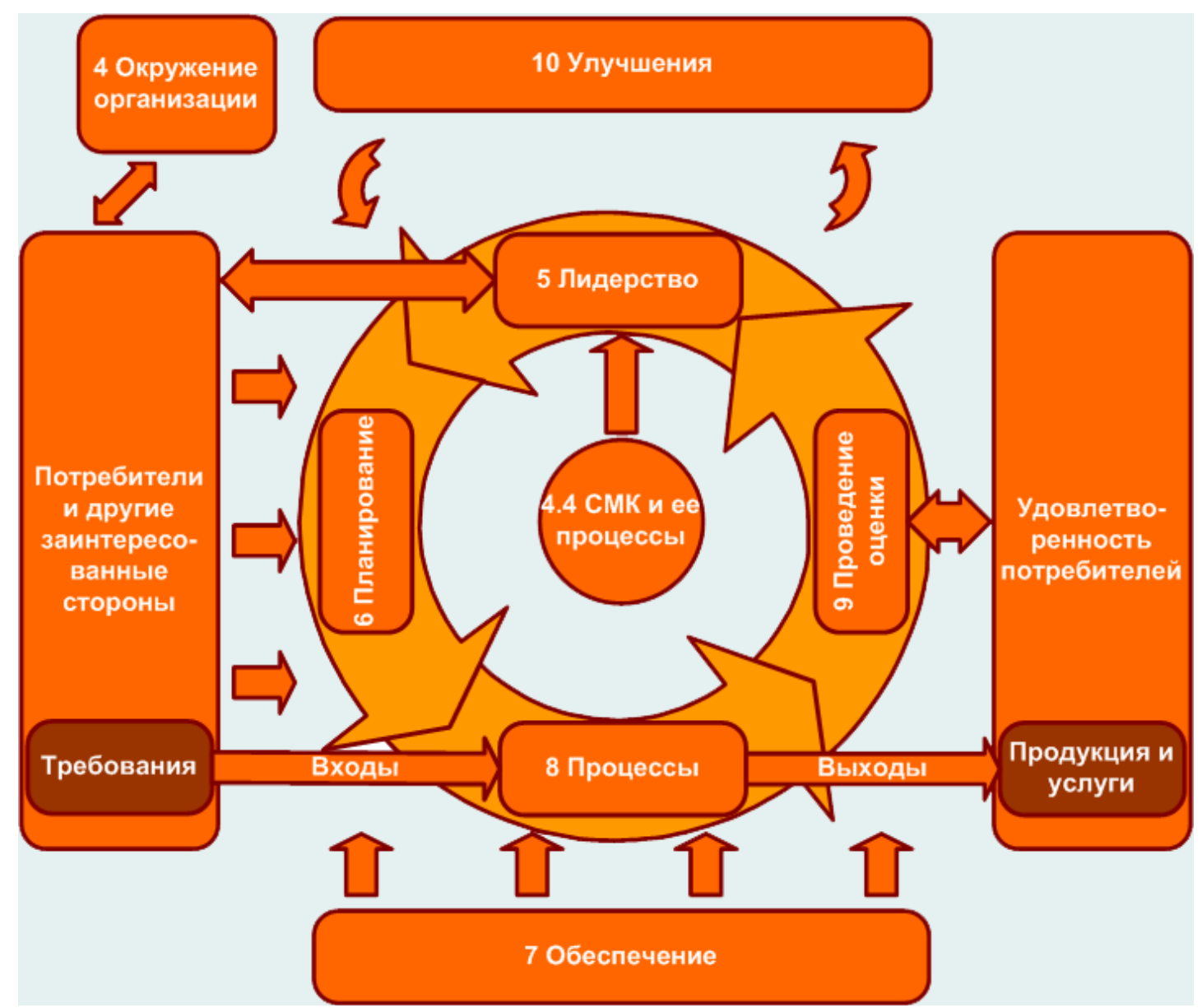

Рисунок 1.1 - Схема процессного подхода.

Система менеджмента качества $\mathrm{AO}$ «ШЗГ» включает:

- структуру управления управляющего директора АО «ШЗГ» и структуры управления структурных подразделений АО «ШЗГ»;

- процессы Системы менеджмента качества $\mathrm{AO}$ «ШЗГ», их применение, последовательность и взаимодействие;

- документацию Системы менеджмента качества АО «ШЗГ», содержащую требования, в соответствии с которыми персонал исполняет деятельность в области качества, и записи (данные), подтверждающие выполнение этих требований;

- ресурсы, необходимые для результативного и эффективного функционирования процессов и Системы менеджмента качества АО «ШЗГ» в целом.

Система менеджмента качества $\mathrm{AO}$ «ШЗГ» функционирует на базе процессов, охватывающих все виды деятельности, определяющие качество выпускаемой продукции. Высшее руководство $\mathrm{AO}$ «ШЗГ» определяет и формирует руководящие, главные и вспомогательные процессы, а также процессы, направленные на постоянное совершенствование системы менеджмента качества $\mathrm{AO}$ «ШЗГ». Решаются задачи определения структуры процессов, их документального оформления, как средства обеспечения реализации Политики АО «ШЗГ» в области качества, достижения целей и соответствия продукции установленным требованиям.

Схема взаимодействия процессов системы менеджмента качества АО «ШЗГ» приведена на рисунке 2.

Перечень процессов системы менеджмента качества АО «ШЗГ» приведен в таблице 1. 


\begin{tabular}{|c|c|c|c|c|c|c|}
\hline \multirow{4}{*}{ Impact Factor: } & ISRA (India) & $=3.117$ & SIS (USA) & $=0.912$ & ICV (Poland) & $=6.630$ \\
\hline & ISI (Dubai, UAE & $=0.829$ & РИНЦ (Russia) & $=0.156$ & PIF (India) & $=1.940$ \\
\hline & GIF (Australia) & $=0.564$ & ESJI (KZ) & $=8.716$ & IBI (India) & $=4.260$ \\
\hline & IIF & $=1.500$ & SIIF (Morocen) & $=5.667$ & OA II (IISA) & $=0.350$ \\
\hline
\end{tabular}

Таблица 1 - Процессы системы менеджмента качества АО «ШЗГ».

\begin{tabular}{|l|l|}
\hline $\begin{array}{l}\text { Код } \\
\text { процесса } \\
\text { СМК }\end{array}$ & Наименование процесса системы менеджмента качества \\
\hline 1 & Руководящие процессы \\
\hline 1.1 & Планирование Системы менеджмента качества \\
\hline 1.2 & Анализ со стороны руководства \\
\hline 1.3 .1 & Подготовка и повышение квалификации персонала \\
\hline 1.3 .2 .1 & Управление железнодорожным транспортом \\
\hline 1.3 .2 .2 & Управление системами управления \\
\hline 1.3 .2 .3 & Управление автотранспортом и спецтехникой \\
\hline 1.3 .2 .4 & Управление строительством и эксплуатацией объектов производственной сферы \\
\hline 1.3 .3 & Управление производственной средой \\
\hline 1.3 .4 & Управление финансово-экономической деятельностью \\
\hline 2 & Главные процессы \\
\hline 2.1 & Анализ контракта, связь с потребителем \\
\hline 2.2 & Проектирование и разработка продукции и технологических процессов \\
\hline 2.3 & Планирование производства \\
\hline 2.4 .1 & Закупки сырья, материалов, оборудования, запасных частей \\
\hline 2.4 .2 & Закупки энергоресурсов \\
\hline 2.5 .1 & Производство чугуна в доменных цехах \\
\hline 2.5 .2 & Производство стальных непрерывно-литых слябов в конвертерных цехах \\
\hline 2.5 .3 & Производство проката в ПГП \\
\hline 2.5 .4 & Производство проката в ПХПП \\
\hline 2.5 .5 & Производство проката электротехнической стали в ПДС \\
\hline 2.5 .6 & Производство проката электротехнической анизотропной стали в ПТС \\
\hline 2.5 .7 & Производство проката низкоуглеродистой стали (в том числе с цинковым покрытием) в ПДС \\
\hline 2.6 & Погрузочно-разгрузочные работы, хранение, упаковка и поставка продукции \\
\hline 3 & Вспомогательные процессы \\
\hline 3.1 & Мониторинг и измерение технологических процессов и продукции \\
\hline 3.2 & Управление оборудованием для мониторинга и измерений \\
\hline 3.3 & Идентификация продукции и прослеживаемость \\
\hline 3.4 & Управление несоответствующей продукцией \\
\hline 3.5 & Техническое обслуживание и ремонты оборудования \\
\hline 4 & Процессы анализа и постоянного улучшения \\
\hline 4.1 & Оценка удовлетворенности потребителя \\
\hline 4.2 & Внутренний аудит \\
\hline
\end{tabular}

Система менеджмента качества $\mathrm{AO}$ «ШЗГ» функционирует следующим образом:

- высшее руководство определяет приоритетные направления деятельности $\mathrm{AO}$ «ШЗГ», формулирует Политику Группы «ШЗГ» в области качества и цели АО «ШЗГ» в области качества. Политику Группы «ШЗГ» в области качества утверждает Президент (председатель Правления );

- управляющий директор АО «ШЗГ» утверждает цели в области качества, проводит совещание руководства АО «ШЗГ» по анализу функционирования системы менеджмента качества;

- уполномоченный руководства АО «ШЗГ» по системе менеджмента качества возглавляет все работы по организации, функционирования и совершенствования системы менеджмента качества $\mathrm{AO}$ «ШЗГ» в соответствии с требованиями «Положения об уполномоченном руководства «АО «ШЗГ» по системе менеджмента качества»;

- Технический центр координирует разработку и внедрение нормативных документов системы менеджмента качества, организует и проводит внутренние аудиты технологических процессов и продукции, участвует в организации внешних аудитов СМК, готовит информацию о функционировании системы менеджмента качества для анализа руководством $\mathrm{AO}$ «ШЗГ»;

- Центр систем менеджмента и научнотехнической информации (ЦСМНТИ) «ШЗГ» организует и проводит внутренние аудиты системы менеджмента качества, организует 


\begin{tabular}{|c|c|c|c|c|c|c|}
\hline \multirow{4}{*}{ Impact Factor: } & ISRA (India) & $=3.117$ & SIS (USA) & $=0.912$ & ICV (Poland) & $=6.630$ \\
\hline & ISI (Dubai, UAE & $=0.829$ & РИНЦ (Russia & $=0.156$ & PIF (India) & $=1.940$ \\
\hline & GIF (Australia) & $=0.564$ & ESJI (KZ) & $=8.716$ & IBI (India) & $=4.260$ \\
\hline & JIF & $=1.500$ & SJIF (Morocco & $=5.667$ & OAJI (USA) & $=0.350$ \\
\hline
\end{tabular}

проведение внешних аудитов органами сертификации;

- руководители структурных подразделений, назначают ответственного структурного подразделения по системе менеджмента качества, организуют деятельность персонала по выполнению требований системы менеджмента качества;

- ответственные структурных подразделений по системе менеджмента качества в соответствии с требованиями «Положения об ответственном структурного подразделения по системе менеджмента качества» организуют работы по эффективному функционированию и постоянному улучшению системы менеджмента качества в структурных подразделениях;

- ответственные за управление документами системы менеджмента качества в структурных подразделениях $\mathrm{AO}$ «ШЗГ» обеспечивают персонал нормативными документами системы менеджмента качества;

- персонал структурных подразделений осуществляет деятельность в соответствии с требованиями системы менеджмента качества.

Схема функционирования системы менеджмента качества АО «ШЗГ» приведена на рисунке 3.

Документацию системы менеджмента качества АО «ШЗГ» формируют в соответствии с требованиями законодательства РФ и межгосударственных, национальных (государственных) стандартов Российской Федерации, а также с учетом требований международных стандартов ISO 9001 и ISO/TS 16949 и требований потребителей.

Документация системы менеджмента качества АО «ШЗГ» включает:

- сформированные высшим руководством АО «ШЗГ» и утвержденные Политику Группы «ШЗГ» в области качества и цели в области качества.

- Руководство по качеству АО «ШЗГ», определяющее систему менеджмента качества AO «ШЗГ» в соответствии с требованиями ISO 9001 и ISO/TS 16949;

- карты процессов, устанавливающие цель процесса, входы и выходы процесса, основные этапы его проведения, ресурсы, параметры и методики контроля; показатели результативности процесса и показатели эффективности (для главных и вспомогательных процессов), действующие документы, в соответствии с требованиями которых осуществляют деятельность по данному процессу;

$$
\text { - стандарты организации системы }
$$
менеджмента качества, устанавливающие процедуры системы менеджмента качества АО «ЩЗГ»;
- документы, разработанные в соответствии с требованиями стандартов предприятия системы менеджмента качества (положения о структурных подразделениях, должностные и производственно-технические инструкции, технологические инструкции, карты последовательности технологических операций, технологические карты, технические условия, стандарты на продукцию и др.);

- организационно-распорядительные документы (приказы, распоряжения руководства AO «ШЗГ».

Структура документального оформления системы менеджмента качества АО «ШЗГ» представлена на рисунке 4.

Политика и Цели в области качества были составлены в соответствии с производственными целями предприятия, документально оформлены и доведены до всех рабочих и служащих предприятия с необходимыми разъяснениями и постановкой конкретных задач перед персоналом и утверждением их приказом. Так как потери за 2017 год составили 16167620 рублей, руководство предприятия, было заинтересовано в реализации спланированных мероприятий, чтобы обеспечить бездефектное производство и улучшение качества продукции.

Учитывая, что бракованные изделия не подлежат восстановлению и ремонту, конструкторским бюро было предложено руководству предприятия их утилизировать, а полученный металл повторно использовать для производства новых изделий, что они и стали делать.

Такой результат стал возможным за счет использования партисипативного управления реализации Политики и целей в области качества и процедур, разработанных руководством предприятия в рамках системы менеджмента качества, формирующие требования ко всем участникам процесса по созданию условий на предприятии для производства бездефектной продукции и при жестком контроле их выполнения.

1.Руководство по качеству. Является основополагающим документом системы менеджмента. Руководство по качеству описывает структуру и содержание системы менеджмента качества, направленную на обеспечение соответствия продукции требованиям потребителя и обязательным требованиям нормативной документации (НД), а также излагает Процедуры (или дает ссылки на них), разработанные в рамках СМК, описывает взаимодействие между процессами системы менеджмента качества.

2. Внутренний аудит системы менеджмента качества. Настоящая процедура является обязательной документированной процедурой, 


\begin{tabular}{|c|c|c|c|c|c|c|}
\hline \multirow{4}{*}{ Impact Factor: } & ISRA (India) & $=3.117$ & SIS (USA) & $=0.912$ & ICV (Poland) & $=6.630$ \\
\hline & ISI (Dubai, UAE & $=0.829$ & РИНЦ (Russia & $=0.156$ & PIF (India) & $=1.940$ \\
\hline & GIF (Australia) & $=0.564$ & ESJI (KZ) & $=8.716$ & IBI (India) & $=4.260$ \\
\hline & JIF & $=1.500$ & SJIF (Morocco & $=5.667$ & OAJI (USA) & $=0.350$ \\
\hline
\end{tabular}

которая устанавливает порядок и последовательность действий при проведении внутренних аудитов (проверок) системы менеджмента качества.

3. «Гарантийный ремонт продукции» Настоящий документ описывает процесс «Гарантийный ремонт продукции» и устанавливает порядок работы с претензиями потребителей.

4. Управление документацией и записями. Управляемыми считаются документы, подготовка, идентификация, рассмотрение, согласование, распределение, хранение и пересмотр которых осуществляется на основе заранее установленных, систематически используемых правил.

5.Управление несоответствующей продукцией. Настоящий документ является обязательной документированной процедурой, которая устанавливает: а) конкретные обязанности структурных подразделений, должностных лиц и отдельных исполнителей по управлению несоответствующей продукцией; б) цели, задачи, сроки, порядок оформления и регистрации записей и документов по управлению несоответствующей продукцией в основном и вспомогательном производстве;

6. Организация контроля качества. Настоящий документ устанавливает: а) порядок организации контроля качества продукции на предприятии; б) конкретные обязанности должностных лиц и отдельных исполнителей по контролю качества продукции предприятия, управлению и идентификации несоответствующей продукции.

7.Закупки. Настоящая процедура устанавливает порядок работы в области оценки и выбора поставщиков, ведения анкеты по поставщикам и определения категории надежности поставщика, определяет единый порядок проведения закупок комплектующих изделий, материалов и полуфабрикатов, их складирования, обеспечения производства и гарантийного обслуживания продукции.

8.Проектирование, разработка продукции и постановка на серийное производство. Настоящий документ устанавливает порядок выполнения процесса «Проектирование, разработка продукции и постановка на производство » и предназначен для: а) регламентации и управления деятельностью подразделения по проектированию и разработке новых видов продукции; б) постоянного улучшения системы менеджмента качества и результатов процесса.

9.Производство продукции. Настоящий документ устанавливает порядок выполнения процесса «Производство продукции» и предназначен для регламентации и управления деятельностью подразделений по производству продукции.

10. Удовлетворенность потребителей. Для определения динамики удовлетворенности потребителя менеджер СМК собирает и систематизирует данные из информационных источников. Источниками информации об удовлетворенности потребителей являются: анкета оценки удовлетворенности потребителя; отзывы потребителей; объемы выпускаемой продукции; объемы отгруженной продукции; премии, награды и дипломы.

11. Технологическая подготовка производства. Настоящий документ устанавливает порядок выполнения процесса «Технологическая подготовка производства» и предназначен для: а) для регламентации и управления деятельностью подразделения по технологической подготовке производства новых видов продукции. б) постоянного улучшения системы менеджмента качества и результатов процесса.

12. Организация и порядок проведения «Дней качества». «День качества» - это оперативное совещание руководителей структурных подразделений, посвященное контролю и анализу качества работы предприятия и его подразделений.

13.Статистические методы управления качеством. Статистический контроль качества продукции является элементом механизма управления качеством продукции и регулирования взаимоотношений между поставщиком и потребителем, при этом проверка группы или партии изделий осуществляется до и после процесса, а не по ходу процесса.

Главная цель применения статистических методов - регулирование процесса создания изделия высокого качества на всех стадиях от маркетинга до технического обслуживания с меньшими экономическими затратами и высокой эффективностью.

Статистические методы предусматривают сбор, систематизацию и математическую обработку результатов производственной деятельности, анализ информации для принятия корректирующих и предупреждающих мер, дальнейшее исследование объекта контроля для достижения приемлемого (оптимального) уровня качества.

Внедрение системы качества представляет собой комплекс работ, который затрагивает различные аспекты деятельности организации и ее подсистемы - подсистему стратегического управления, производственную подсистему, подсистему логистики, управление персоналом, внутренние коммуникации, документооборот и др. В связи с этим, внедрение системы качества является достаточно трудной, длительной и 


\begin{tabular}{|c|c|c|c|c|c|c|}
\hline \multirow{4}{*}{ Impact Factor: } & ISRA (India) & $=3.117$ & SIS (USA) & $=0.912$ & ICV (Poland) & $=6.630$ \\
\hline & ISI (Dubai, UAE & $=0.829$ & РИНЦ (Russia & $=0.156$ & PIF (India) & $=1.940$ \\
\hline & GIF (Australia) & $=0.564$ & ESJI (KZ) & $=8.716$ & IBI (India) & $=4.260$ \\
\hline & JIF & $=1.500$ & SJIF (Morocco & $=5.667$ & OAJI (USA) & $=0.350$ \\
\hline
\end{tabular}

трудоемкой задачей. Решение этой задачи, как правило, происходит в несколько этапов.

Основные этапы внедрения СМК следующие:

Совершенствование СМК имеет смысл, только в том случае если у коллектива предприятия есть желание добиться весомых результатов в борьбе за качество своей продукции, но все это должно провоцировать желание коллектива достичь новых высот, двигаться вперед и гарантировать себе и своему предприятию стабильные результаты своей деятельности.

Для реализации сформулированных процедур пожеланий должны быть выполнены следующие мероприятия, а именно:

* шаг 1 - осознание высшим руководством цели создания и внедрения СМК на предприятии;

* шаг 2 - установление потребностей $u$ ожиданий потребителей $и$ других заинтересованных сторон;

* шаг 3 - формирование стратегии управления, Политики и Целей в области качества

* шаг 4 - организация обучения в области качества всех сотрудников; $C M K$;

* маг 5 - планирование работ по внедрению

* шаг 6-внедрение СМК с формированием команды, состоящей из различных специалистов;

* шаг 7 - установление системы процессов, их согласованной взаимосвязи и взаимодействия, выделение ключевых процессов, необходимых для достижения иелей в области качества;

* шаг 8 - документирование СМК (в том объеме и степени конкретизации, необходимом именно для вашей организации - не забывая об обязательности некоторой документации в соответствии с требованиями ИСО 9001-2015);

* шаг 9 - внутренние аудить;

* шаг 10 - доработка документации СМК и устранение замечаний по результатам внутренних аудитов и отработки при внедрении в действие разработанной нормативной документациин;

* шаг 11 - сертификаџия СМК;

* шаг 12 - дальнейшее развитие СМК.

AO «Шахтинский завод Гидропривод» определило и осуществляет менеджмент многочисленных взаимосвязанных видов деятельности. Процедуры были идентифицированы, описаны и задокументированы.

Кроме того, АО «Шахтинский завод Гидропривод» разработало, задокументировало, внедрило и поддерживает в рабочем состоянии систему менеджмента качества, что обеспечило ему постоянно улучшение его результативности в соответствии с требованиями ГОСТ Р ИСО 9001: 2015.

Таки процедурами в рамках системы менеджмента качества являются:

Основные процедуры:

^ проектирование, разработка, изготовление опытных образцов и постановка на серийное производство ГП $08-01$;

^ составление плана производства ГП 03-01;

* контроль и проведение испытаний продукции.

^ упаковка и хранение (производится согласно типовых и индивидуальных технологических процессов на каждое изделие);

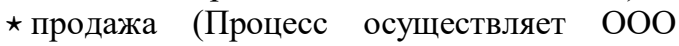
«Торговый Дом Гидропривод»;

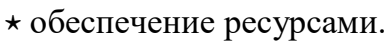

Процедуры менеджмента:

^ процессы управленческой деятельности руководства;

夫 проведение маркетинговых исследований;

АО «Шахтинский завод Гидропривод»:

^ определило последовательность и взаимодействие процессов;

夫 определило для каждой процедуры критерии и методы, необходимые для обеспечения результативности, как при осуществлении, так и при управлении этими процедурами.

Порядок выбора критериев изложен в ГП 0101 «Порядок разработки, оформления, согласования и утверждения процессов системы менеджмента качества» и предполагает:

*обеспечивать для каждого процесса наличие ресурсов и информации, необходимых для поддержки этих процессов и их мониторинга;

* осуществлять мониторинг, измерение и анализ этих процессов;

* принимать меры, необходимые для достижения запланированных результатов и постоянного улучшения этих процессов.

Переданные ООО «Торговый Дом Гидропривод» процессы обеспечены управлением: в части маркетинга - это совместное участие в выставках, выдача задания на проведение рекламы и исследования тенденций рынка, в части продажи- это договор на реализацию продукции.

Результаты разработки, документирования и внедрения системы менеджмента качества подтверждаются внутренним аудитом (ГП 13-03), проводимым по программе аудита 2 раз в год.

Внутренние аудиты СМК на предприятии проводятся с целью:

* проверки соответствия СМК АО «ШЗГ» требованиям ISO 9001:2008 (ГОСТ Р ИСО 90012015); 


\begin{tabular}{|c|c|c|c|c|c|c|}
\hline \multirow{4}{*}{ Impact Factor: } & ISRA (India) & $=3.117$ & SIS (USA) & $=0.912$ & ICV (Poland) & $=6.630$ \\
\hline & ISI (Dubai, UAE & $=0.829$ & РИНЦ (Russia) & $=0.156$ & PIF (India) & $=1.940$ \\
\hline & GIF (Australia) & $=0.564$ & ESJI (KZ) & $=8.716$ & IBI (India) & $=4.260$ \\
\hline & JIF & $=1.500$ & SJIF (Morocco & $=5.667$ & OAJI (USA) & $=0.350$ \\
\hline
\end{tabular}

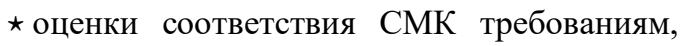
установленным внутренней документацией АО «ШЗГॅ»;

^ оценки способности СМК к результативному и эффективному функционированию;

^ проверки выполнения и результативности корректирующих и предупреждающих действий по несоответствиям, выявленным при проведении предыдущих аудитов;

^определения областей деятельности для улучшения, возможности и путей совершенствования СМК. Внутренние аудиты (проверки) проводятся:

* плановый аудит - 2 раза в год согласно программе проведения внутреннего аудита СМК, утвержденной вместе с приказом о проведении внутренних аудитов Управляющим «АО «ШЗГ».

* внеплановый аудит - основанием для него служит:

* увеличение количества замечаний или рекламаций на выпускаемую продукцию;

* ухудшение качества выпускаемой продукции;

* проверка реализации корректирующих и предупреждающих действий и оценки их эффективности;

* изменения структуры управления предприятием;

* необходимость совершенствования процедур, процессов СМК предприятия;

* иные причины.

Аудиты может проводить как менеджер по СМК, так и другие работники предприятия.

Подбор группы по аудиту осуществляет заместитель исполнительного директора по качеству с учетом необходимости обеспечения независимости аудиторов от проверяемой деятельности; или иных факторов, способных оказать влияние на результативность и эффективность внутреннего аудита СМК.

Главный аудитор с группой по аудиту в ходе проведения внутреннего аудита СМК осуществляют сбор информации с целью проверки соответствия СМК требованиям международного стандарта ГОСТ Р ИСО 9001:2015, выполнения требований потребителя и требований документов СМК, результативности и эффективности внедрения записей и поддержания их в рабочем состоянии, знания и понимания Политики и Целей предприятий в области качества, степень достижения целей в области качества, определения возможности улучшения СМК.

Методы сбора информации включают:

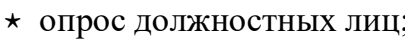

* наблюдение за деятельностью, производственной средой;

* анализ документации.
Информация, выявленная в процессе внутреннего аудита СМК, фиксируется аудиторами.

По окончании аудита главный аудитор составляет отчет по внутреннему аудиту СМК. Отчет должен содержать полную, точную и однозначно понимаемую информацию по проведенному аудиту. Этот отчет является одним из видов записей по качеству и необходим для оценки СМК и принятия решений об ее улучшении. Копии отчета направляются руководителям структурных подразделений и высшему руководству.

АО «ШЗГ» планирует и проводит проверки системы менеджмента качества в соответствии с ГП 13-03 «Внутренний аудит системы менеджмента качества»

Высшее руководство ежеквартально анализирует систему менеджмента качества с целью обеспечения ее постоянной пригодности, адекватности и результативности. В анализ включается оценка возможностей улучшения и потребности в изменениях в системе менеджмента качества организации, в том числе в Политике и целях в области качества.

На АO «Шахтинский завод Гидропривод» руководство по качеству является основным определяющим документом системы менеджмента качества и описывающим ее в соответствии с требованиями ГОСТ Р ИСО 9001: 2015.

Общие требования к продукции в части установления технических параметров, санитарных норм и техники безопасности определяются ГОСТ РФ, а на каждое изделие разработаны и утверждены в установленном порядке технические условия, где определены конкретные значения рабочих параметров гидронасоса.

АО «Шахтинский завод Гидропривод» определило и осуществляет менеджмент многочисленных взаимосвязанных видов деятельности. Деятельность, использующая ресурсы и управляемая с целью преобразования входов в выходы, рассматривается как процесс.

Преимущество процессного подхода состоит в непрерывности управления, которое он обеспечивает на стыке отдельных процессов в рамках системы, а также при их комбинации и взаимодействии.

АО «Шахтинский завод Гидропривод», будучи заинтересовано в постоянном улучшении качества производимой продукции, осуществляет планирование и реализацию необходимых процессов проверки, анализа и улучшения.

Данные, свидетельствующие об удовлетворении интересов и требований потребителей в области конструктивных особенностей, изучает конструкторский отдел. 


\begin{tabular}{|c|c|c|c|c|c|c|}
\hline \multirow{4}{*}{ Impact Factor: } & ISRA (India) & $=3.117$ & SIS (USA) & $=0.912$ & ICV (Poland) & $=6.630$ \\
\hline & ISI (Dubai, UAE & $=0.829$ & РИНЦ (Russia) & $=0.156$ & PIF (India) & $=1.940$ \\
\hline & GIF (Australia) & $=0.564$ & ESJI (KZ) & $=8.716$ & IBI (India) & $=4.260$ \\
\hline & JIF & $=1.500$ & SJIF (Morocco & $=5.667$ & OAJI (USA) & $=0.350$ \\
\hline
\end{tabular}

Источниками получения таких данных является переписка, служба маркетинга ООО «Торговый Дом Гидропривод» и службы качества.

Целью исследования мнения потребителей является определение степени их удовлетворенности выпускаемой продукции и принятия решения и мероприятия по еe повышению.

Уровень удовлетворенности потребителей качеством выпускаемой продукции является важным критерием результативности СМК и партисипативного управления.

Удовлетворенность потребителей измеряется путем сбора и анализа соответствующей информации, включая обратную связь с потребителем.

По

результатам

измерения

удовлетворенности потребителей оформляется, а отчет по анализу СМК со стороны высшего руководства.

Претензии потребителей, как восприятие неудовлетворенности, собирают и обрабатывают в службе маркетинга и служба качества.

Сбор пожеланий осуществляют:

* путем сбора информации от потребителей;

*обеспечение потребителей информацией о новых достижениях в области повышения качества продукции с помощью рассылки рекламных проспектов и информационных листов;

* участия в выставках (ярмарках).

На заводе проводятся внутренние аудиты не реже 2 раза в год с целью установления того, что система менеджмента качества:

* соответствует ли требованиям ГОСТ $\mathrm{P}$ ИСО 9001:2015;

* эффективно ли действует СМК.

Программа аудитов планируется с учетом статуса и важности процессов и участников, подлежащих аудиту, а также результатов предыдущих аудитов. Критерии, область применения, частота и методы аудитов определены ГП 13 - 03. Выбор аудиторов обеспечивает объективность и беспристрастность процесса аудита. Аудиторы не проверяют свою собственную работу. Руководство, ответственное за проверяемые области деятельности, должно обеспечивать, чтобы действия предпринимались без излишней отсрочки для устранения обнаруженных несоответствий и вызвавших их причин. Последующие действия должны включать верификацию предпринятых мер и отчет о результатах верификации.

На АО «Шахтинском заводе Гидропривод» применяются методы контроля и, где это целесообразно, измерения процессов системы менеджмента качества. Целью деятельности по мониторингу и измерениям процессов является:
* проверка соблюдения требований, предъявляемым к процессам (ГП $01-01)$;

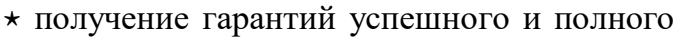
осуществления запланированных действий;

夫 получение данных для анализа и поиска путей улучшения процессов в СМК в целом.

Ответственность за функционирование и постоянное улучшения деятельности по мониторингу и измерениям процессов возлагается на Представителя высшего руководства СМК. Мониторинг и измерение функционирования процессов СМК проводят их владельцы с использованием подчиненного персонала, технических средств, соответствующих процедур сбора, накопления, передачи и анализа информации, в зависимости от конкретного процесса.

Мониторинг и измерение характеристик продукции с целью сверки соблюдения требований к продукции. Это осуществляется на соответствующих этапах процесса жизненного цикла продукции.

Параметры измерения продукции определяет конструкторский отдел на основании технических условий и выдает задание на разработку стендов для испытания продукции.

Метрологическая служба на основании Положения о метрологической службе проводит метрологическую экспертизу выбранному методу измерения и приборов, на основании показаний которых получают объективные свидетельства качества произведенной продукции. На участке испытаний производится обкатка изделий на специальных стендах и снятие характеристик, которое проводится под контролем ОТК.

Для повышения качества производимой продукции на предприятии должна иметь место собственная СМК. В большинстве случаев высшее руководство внедряет стандарты ИСО серии 9000 , преследуя одну из двух основных целей:

* использование их как средство повышения эффективности деятельности предприятия, а затем, по мере необходимости, сертификации СМК на соответствие требованиям стандартов;

* внедрение их только с целью сертификации СМК.

В АО «Шахтинский завод Гидропривод» внедрена и функционирует документированная процедура «Гарантийный ремонт продукции» на AO «Шахтинский завод Гидропривод». Разработан стандарт ГП 13-06 ОТ 03.02.2016 г., в котором описана данная процедура.

Необходимость разработки проекта стандарта «Управление несоответствующей продукцией в Ремонтном производстве» на АО «Шахтинский завод Гидропривод» обусловлена тем, что действующий на предприятии ГП 13-06 не содержит единую схему, включающую в себя все возможные варианты управления 


\begin{tabular}{|c|c|c|c|c|c|c|}
\hline \multirow{4}{*}{ Impact Factor: } & ISRA (India) & $=3.117$ & SIS (USA) & $=0.912$ & ICV (Poland) & $=6.630$ \\
\hline & ISI (Dubai, UAE & $=0.829$ & РИНЦ (Russia) & $=0.156$ & PIF (India) & $=1.940$ \\
\hline & GIF (Australia) & $=0.564$ & ESJI (KZ) & $=8.716$ & IBI (India) & $=4.260$ \\
\hline & JIF & $=1.500$ & SJIF (Morocco & $=5.667$ & OAJI (USA) & $=0.350$ \\
\hline
\end{tabular}

несоответствующей продукцией, a также спецификой операций технологического процесса производства продукции в цехах Ремонтного производства, которые могут служить причиной возникновения различных дефектов

\section{References:}

1. Prokhorov, V. T. (2009). Recommendations to Shoe enterprises of the southern Federal district on their way out of the economic crisis: monograph. (p.658). Mine: GOU VPO yurgues.

2. Prokhorov, T. V., et al. (2009). How to ensure sustainable demand for domestic products in the fashion industry. monograph under the General editorship of Professor V. T. Prokhorov (Eds.). GOU VPO "South-ROS. University of Economics and service". (p.494). Mine: Publishing house GOU VPO yurgues.

3. Fatkhutdinov, R. A. (2000). Competitiveness: Economics, strategy, management. (p.312). Moscow: INFRA-M.

4. Mishin, Y. D., et al. (2009). Quality management of competitive and in-demand materials and products. monograph. under the General editorship of V. T. Prokhorov (Eds). (p.443). Mine: GOU VPO yurgues.

5. Prokhorov, V. T., et al. (2009). How to ensure sustainable demand for domestic products in the fashion industry. Monograph. under the General editorship of V. T. Prokhorov (Eds.). (p.494). Mine: GOU VPO yurgues.

6. Volkova, G. (2009). how to increase the competitiveness of the Russian leather and footwear industry? [Text] Step new, №6 (53), 92-93.

7. Romanova, L. A., Tomilin, L. B., \& Prokhorov, V. T. (2010). On the formation mechanisms for sustainable quality products manufactured Shoe enterprises in the Shoe cluster [Text]. Leather and footwear industry, Moscow, № 2, 18-21.

8. Romanova, L. A., Tomilin, L. B., Volkova, G. Y., Prokhorov, V. T., \& Prokhorov, E. V. (2010). On the formation mechanisms for sustainable development of Shoe enterprises in the cluster //Technical regulation: the basis of quality of materials, goods and services. international collection of scientific works/ redkol.: monograph [Text] [etc.]/ V. T. Prokhorov, etc.; under the General editorship of Professor V. T. Prokhorov (Eds.). (p.234, pp.44-46). Mine: Publishing house GOU VPO yurgues.

9. Romanova, L. A., Tomilin, L. B., Prokhorov, V. T., Volkov, G. Yu., Polyakova, V. A., Prokhorova, E. V., \& Frost, B. (2010). On the search for effective methods for assessing the impact of factors on the performance of industrial and economic activities of the cluster [Text]/ proceedings of higher education institutions. North Caucasus region. Technical science, Novocherkassk, №6 (149), 127-135.

10. Romanova, L. A., Tomilin, L. B., Prokhorov, E. V., Osicka, N. I., Aspen, T. M., Prokhorov, V. T., \& Volkov, Y. G. (2011). Organizational and production sustainable development of the cluster formed on the basis of footwear enterprises in the southern and North Caucasus Federal district [Text]/ Leather and footwear industry, Moscow, № 1, 17-21.

11. Romanova, L., Tomilina, L., Budkova, V., Prokhorov, V., \& Meleshko, E. (2010). The role of clusters to provide the regions of the southern and North Caucasus Federal districts with competitive and in-demand products [Text] / Collection of scientific works Socio-economic and technical-technological problems of the development of the Vyp service sector. 9 Part 2 RTIST branch of GOU VPO "YURGU-ES". (p.420, pp.34-37). Rostov - on - don RTIST "yurgues".

12. Romanova, L. A., Tomilin, L. B., Prokhorov, E. V., Osicka, N. I., Aspen, T. M., Prokhorov, V. T., Volkov, Y. G. (2011). Organizational and production sustainable development of the cluster formed on the basis of footwear enterprises in the southern and North Caucasus Federal district [Text]/ Leather and footwear industry, Moscow, № 6, 32 - 36 the second message

13. Romanova, L. A., Tomilin, L. B., Prokhorov, V. T., Zverev, S. M., ASP, T. M., \& Nikitina, E. V. (2011). About management decisions promote the products of the fashion industry in terms of risk [Text] / "Director" is the magazine for executives No. 3, (128), 10-11. Leg-Prom business.

14. Romanova, L. A., Osina, T. M., \& Abduzhamalova, M. A. (2011). on the ways of economic development of footwear enterprises in the regions of the southern Federal district and the southern Federal district [Text] / New in technology and technology of textile and light industry: proceedings of the international scientific conference. (pp.100-104). Vitebsk, 


\begin{tabular}{|c|c|c|c|c|c|c|}
\hline \multirow{4}{*}{ Impact Factor: } & ISRA (India) & $=3.117$ & SIS (USA) & $=0.912$ & ICV (Poland) & $=6.630$ \\
\hline & ISI (Dubai, UAE & $=0.829$ & РИНЦ (Russia & $=0.156$ & PIF (India) & $=1.940$ \\
\hline & GIF (Australia) & $=0.564$ & ESJI (KZ) & $=8.716$ & IBI (India) & $=4.260$ \\
\hline & JIF & $=1.500$ & SJIF (Morocco & $=5.667$ & OAJI (USA) & $=0.350$ \\
\hline
\end{tabular}

November 2011 at 2 h. 2 / UO "VSTU". Vitebsk.

15. Romanova, L., Prokhorov, V. T., Kosova, T. A., Kompanchenko, E. V., \& Osina, T. M. (2011). New technologies in textile and light industry: proceedings of the international scientific conference. (pp.104-107). Vitebsk, November 2011 at 2 h. 2 / UO "VSTU". - VI-tebsk.

16. Prokhorov, T. V., et al. (2009). How to ensure sustainable demand for domestic products in the fashion industry: monograph / under the General editorship of Professor V. T. Prokhorov (Eds.). GOU VPO "South-ROS. University of Economics and service". (p.494). Mine: Publishing house GOU VPO yurgues.

17. Romanova, L. A., et al. (2011), the Effect of cash flow on the efficiency of the results of the cluster formed on the basis of footwear enterprises the SFD and NCFD: monograph. (pp.211-265). Mines: FGBOU VPO yurgues.

18. Romanova, L. A., et al. (2011). Software for calculation of the main technical and economic indicators of the enterprise performance certificate $R F$ on state registration of computer programs №2011616317// Was registered on 11 Aug 2011.

19. Imai, M. (2005). Gemba Kaizen: a Way to reduce costs and improve quality. TRANS. with
English. (p.346). Moscow: Alpina Business Books.

20. Porter, M. (2005). Competition / Per. with English. (p.608). Moscow: Ed. house "Williams".

21. Pande, P., Kholp (2004). "What is ' Six Sigma'? Revolutionary method". TRANS. with English. (p.158). Moscow: OK Mountaineering. Business Books.

22. Womak, J. P., \& Jones D. T. (2005). Lean manufacturing: How to eliminate losses and to achieve prosperity of your company [Text] lane.from English. - 2nd ed. (p.473). Moscow: Alpina Business Books.

23. Michael, G. L. (2005). Lean manufacturing + six Sigma: combining the quality of six Sigma with the speed of lean manufacturing [Text] TRANS. (p.360). Moscow: Alpina Business books.

24. Shingo, S. (2006). Quick changeover: the revolutionary technology of optimization of production [Text] (p.344). Moscow: Alpina Business Books.

25. Vader, M. (2005). lean production Tools: $\mathrm{Mi}-\mathrm{Ni}$ guide to the implementation of lean production techniques [Text] lane.from English. (p.125). Moscow: Alpina Business Books. 